MATEUS DE LARA RIBEIRO

Definição, implementação e validação de técnicas de retorno háptico para treinamento virtual em exame de palpação mamária

São Paulo

2016 


\section{Definição, implementação e validação de técnicas de retorno háptico para treinamento virtual em exame de palpação mamária}

Dissertação apresentada à Escola de Artes, Ciências e Humanidades da Universidade de São Paulo para obtenção do título de Mestre em Ciências pelo Programa de Pós-graduação em Sistemas de Informação.

Área de concentração: Metodologia e Técnicas da Computação

Versão corrigida contendo as alterações solicitadas pela comissão julgadora em 17 de Dezembro de 2015. A versão original encontra-se em acervo reservado na Biblioteca da EACH-USP e na Biblioteca Digital de Teses e Dissertações da USP (BDTD), de acordo com a Resolução CoPGr 6018, de 13 de outubro de 2011.

Orientador: Profa. Dra. Fátima de Lourdes dos Santos Nunes Marques

São Paulo

2016 
Autorizo a reprodução e divulgação total ou parcial deste trabalho, por qualquer meio convencional ou eletrônico, para fins de estudo e pesquisa, desde que citada a fonte.

CATALOGAÇÃO-NA-PUBLICAÇÃO

(Universidade de São Paulo. Escola de Artes, Ciências e Humanidades. Biblioteca)

Ribeiro, Mateus de Lara

Definição, implementação e validação de técnicas de retorno háptico para treinamento virtual em exame de palpação mamária / Mateus de

Lara Ribeiro ; orientadora, Fátima de Lourdes dos Santos Nunes

Marques. - São Paulo, 2016

116 f. : il.

Dissertação (Mestrado em Ciências) - Programa de Pós-

Graduação em Sistemas de Informação, Escola de Artes, Ciências

e Humanidades, Universidade de São Paulo, em 2015

Versão corrigida

1. Realidade virtual. 2. Exames médicos - Simulação. 3.

Mama. 4. Médicos - Treinamento. I. Marques, Fátima de Lourdes dos Santos Nunes, orient. II. Título

CDD 22.ed. - 006.8 
Dissertação de autoria de Mateus de Lara Ribeiro, sob o título "Definição, implementação e validação de técnicas de retorno háptico para treinamento virtual em exame de palpação mamária", apresentada à Escola de Artes, Ciências e Humanidades da Universidade de São Paulo, para obtenção do título de Mestre em Ciências pelo Programa de Pós-graduação em Sistemas de Informação, na área de concentração Metodologia e Técnicas da Computação, aprovada em 17 de Dezembro de 2015 pela comissão julgadora constituída pelos doutores:

Profa. Dra. Fátima de Lourdes dos Santos Nunes Marques

Presidente

Instituição: Escola de Artes, Ciências e Humanidades - Universidade de São Paulo

Prof. Dr. Ricardo Nakamura

Instituição: Escola Politécnica - Universidade de São Paulo

Prof. Dr. Henrique Manoel Lederman

Instituição: Universidade Federal de São Paulo 
Dedico este trabalho a Deus e aos amores da minha vida: minha família e minha namorada. 


\section{Agradecimentos}

Primeiramente, agradeço a Deus por iluminar e abençoar minha vida com a graça de poder trilhar mais este caminho.

À minha família, pelo apoio incondicional em todas as decisões tomadas por mim, assim como toda a ajuda e amor que somente ela poderia dar, em todos os momentos.

À minha namorada, pelo amor, pelo carinho, pelo zelo que nunca me deixou desamparado, pelo entusiasmo incrível que nunca me deixou desanimar e também pela compreensão, principalmente nos momentos em que precisei me dedicar exclusivamente ao mestrado.

À Profa. Dra. Fátima de Lourdes dos Santos Nunes Marques, pela paciência, dedicação singular e acima de tudo, pela excelente orientação. Sinto-me honrado e infinitamente grato pelo privilégio pela oportunidade de trabalhar com você.

Aos grandes amigos da SKY, por todo apoio e descontração, que me fizeram lembrar como este trabalho também deveria ser divertido. Em especial, ao Theófilo e Bruno, pelo voto de confiança e respaldo dado desde o início, que permitiram que eu seguisse este caminho.

Aos grandes amigos da faculdade, pelo incentivo a seguir este caminho e pela ajuda nos momentos de dificuldade. Eiji, Berry, Roberth e Danet, obrigado pela amizade.

Aos amigos do mestrado, por todo o auxílio e companheirismo ao longo desta jornada.

Aos professores do curso de mestrado, aos revisores, pelo conhecimento e experiências compartilhadas.

À Dra. Simone Elias, pela contribuição na avaliação do projeto. 


\section{Resumo}

RIBEIRO, Mateus de Lara. Definição, implementação e validação de técnicas de retorno háptico para exame de palpação mamária. 2016. 116 f. Dissertação (Mestrado em Ciências) - Escola de Artes, Ciências e Humanidades, Universidade de São Paulo, São Paulo, 2015.

O exame de palpação é um procedimento no qual um profissional da saúde pressiona uma região específica do corpo de um paciente com os dedos a fim de detectar a presença ou ausência de características e anormalidades sob a pele. Um simulador que forneça subsídios para o treinamento deste procedimento pode contribuir para o aprendizado da técnica e o aprimoramento de sua execução em pacientes, além de, dentre outras vantagens, eliminar a necessidade de exposição de pacientes aos riscos das situações reais, minimizar o uso de objetos físicos e tornar possível a simulação de diferentes casos e ações. O objetivo principal deste trabalho consiste em desenvolver um simulador de palpação mamária com retorno háptico realista. No contexto do exame de palpação, existe uma lacuna no que concerne a definição de técnicas e parâmetros de retorno de força que ofereçam uma experiência mais realista de interação para o usuário. Após uma revisão sistemática da literatura foi feito o mapeamento dos principais parâmetros para representar diferentes nódulos durante o treinamento virtual visando ao diagnóstico de anomalias mamárias. Tais parâmetros foram equacionados com a finalidade de obter uma representação realista em um dispositivo háptico. Além disso, interfaces foram implementadas para permitir a geração de casos com a variação desses parâmetros referentes aos nódulos (tamanho, consistência, localização e contorno). Os resultados obtidos a partir de uma avaliação com uma profissional da medicina mostraram que o retorno de força aplicado a cada uma das características foi realista para todos os parâmetros, com limitação na representação de nódulos espiculados, que deve ser melhorada. Além de contribuir com a área de Computação no sentido de ter definido técnicas e parâmetros de retorno de força importantes para a simulação de exames de palpação, o trabalho disponibiliza uma ferramenta que pode contribuir para a aquisição efetiva da habilidade necessária para a execução do procedimento em questão.

Palavras-chaves: Exame de Palpação. Simulação. Retorno Háptico. Retorno de Força. Realidade Virtual. Treinamento Médico Virtual. 


\begin{abstract}
RIBEIRO, Mateus de Lara. Definition, implementation and validation of haptic feedback techniques for virtual training on breast palpation examination.

2016. 116 p. Dissertation (Master of Science) - School of Arts, Sciences and Humanities, University of São Paulo, São Paulo, 2015.

Palpation exam is a procedure in which a health care professional presses a specific region of a patient's body with the fingers in order to detect the presence of features and abnormalities under the skin. A simulator that aids the training this procedure may contribute to the learning of the technique and the improvement of its implementation in real patients. The main objective of the Master's degree work proposed in this paper is to develop a breast palpation simulator with haptic feedback. The results of a Systematic Review conducted in order to assess the state-of-art of the simulation of the palpation procedure showed that despite being a new area, there are already many innovative works that received positive reviews. However, in the context of palpation examination, a gap exists regarding the definition of techniques and force feedback parameters to provide a more realistic experience to the user. After a Systematic Review from the literature the mapping of the main parameters was done to represent different nodules during the virtual training for the diagnosis of breast abnormalities. These parameters were transformed into equations with the goal of obtaining a realistic representation on a haptic device. Besides, user interfaces were implemented to allow the creation of cases with the variation of the parameters relative to the nodules (size, consistency, localization and contour). The results obtained from an assessment done with a medical professional showed that the force feedback applied to each one of the characteristics was realistic to all the parameters, with limitations on the representation of spiculated nodules, which must be improved. Aside from the contribution to the Computing area in the sense that force feedback techniques and parameters important to the simulation of palpation exams were defined, this work offers a tool that can contribute to the effective acquisition of the necessary skills to the execution of the procedure in question.
\end{abstract}

Keywords: Palpation Exam. Simulation. Haptic Feedback. Force Feedback. Virtual Reality. Virtual Medical Training. 


\section{Lista de figuras}

Figura 1 - Palpação abdominal . . . . . . . . . . . . . . . 20

Figura 2 - Palpação da mama . . . . . . . . . . . . . . . . . 21

Figura 3 - Kyoto breast task trainer . . . . . . . . . . . . . . . . 22

Figura 4 - Gaumard breast task trainer . . . . . . . . . . . . . 23

Figura 5 - MammaCare CBE simulation training . . . . . . . . . . . . 23

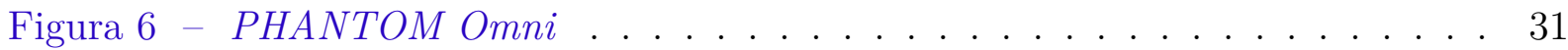

Figura 7 - 5DT Ultra Wireless Kit . . . . . . . . . . . . . . . . 32

Figura 8 - PHANTOM Premium 1.5/6DOF . . . . . . . . . . 32

Figura 9 - Óculos esteroscópicos para visualização de anaglifos . . . . . . . . . . . 33

Figura 10 - Óculos estereoscópicos . . . . . . . . . . . . . . . . . . 34

Figura 11 - 5DT Head Mounted Display . . . . . . . . . . . . . . . . . . 34

Figura 12 - Diagrama de fluxo sumarizando a etapa de seleção de estudos. . . . . . 38

Figura 13 - Gráfico de quantidade de trabalhos no tempo. . . . . . . . . . . . . . . 39

Figura 14 - Gráfico de dispositivos hápticos utilizados nos trabalhos. . . . . . . . . 39

Figura 15 - Gráfico de áreas de aplicação dos trabalhos. . . . . . . . . . . . . . . . 40

Figura 16 - Gráfico de quantidade de pontos de contato utilizados. . . . . . . . . . 41

Figura 17 - Objeto virtual representando a mama. . . . . . . . . . . . . . . . . 59

Figura 18 - Objeto virtual representando mão humana, com iluminação refletora e cor clara. . . . . . . . . . . . . . . . . . . 6 60

Figura 19 - Objeto virtual representando nódulo redondo. . . . . . . . . . . . . . . 60

Figura 20 - Objeto virtual representando nódulo redondo dentro de uma mama virtual transparente. . . . . . . . . . . . . . . . . 6 61

Figura 21 - Representação em árvore do processo de detecção de colisão utilizando

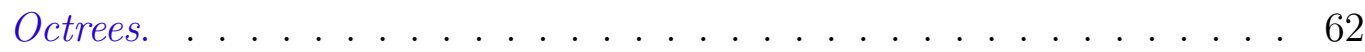

Figura 22 - Deformação da mama. . . . . . . . . . . . . . . . 63

Figura 23 - Diagrama de ações após a detecção de colisão. . . . . . . . . . . . . . . 65

Figura 24 - Diagrama de classes do framework ViMeT. . . . . . . . . . . . . . . . 66

Figura 25 - Diagrama de interação do sistema com o dispositivo háptico. . . . . . . 67

Figura 26 - Plano de corte para a extensão de acrílico: duas peças laterais (esquerda) e uma base (direita). . . . . . . . . . . . . . . . . 69

Figura 27 - Adaptação realizada no dispositivo háptico para realização da palpação 70 
Figura 28 - Três diferentes tamanhos de nódulos: a) $0.5 \mathrm{~cm}$; b) $1 \mathrm{~cm}$; c) $2 \mathrm{~cm}$. . . 73

Figura 29 - Fluxo de definição do posicionamento do nódulo. . . . . . . . . . . . . 74

Figura 30 - Alerta de força máxima no simulador. . . . . . . . . . . . . . 76

Figura 31 - Fluxo de interação do instrutor com o simulador. . . . . . . . . . . . . 76

Figura 32 - Interface para definição da quantidade de casos. . . . . . . . . . . . . . 77

Figura 33 - Interface para escolha das características. . . . . . . . . . . . . 77

Figura 34 - Interface para definição dos parâmetros. . . . . . . . . . . . . . . . 78

Figura 35 - Simulação do exame de palpação da mama com a estrutura do nódulo invisível. . . . . . . . . . . . . . . . . . . . . . . 79

Figura 36 - Simulação do exame de palpação da mama com a estrutura do nódulo posicionada no canto inferior direito da mama. . . . . . . . . . . . . . 82

Figura 37 - Simulação do exame de palpação da mama utilizando o recurso de estereoscopia. . . . . . . . . . . . . . . . . . . 82

Figura 38 - Dispositivo háptico Phantom Omni . . . . . . . . . . . . . . . 84 


\section{Lista de tabelas}

Tabela 1 - Vetores utilizados para cálculo da colisão . . . . . . . . . . . . . . 64

Tabela 2 - Constantes utilizadas para os nódulos. . . . . . . . . . . . . 72

Tabela 3 - Posicionamento do nódulo na mama . . . . . . . . . . . . 73

Tabela 4 - Intervalos de valores de posicionamento (mama esquerda) . . . . . . 73

Tabela 5 - Características disponíveis para seleção . . . . . . . . . . . . 77

Tabela 6 - Parâmetros disponíveis para configuração . . . . . . . . . . 78

Tabela 7 - Artigos incluídos na Revisão Sistemática . . . . . . . . . . . . . 108 


\section{Lista de abreviaturas e siglas}

$\begin{array}{ll}\text { API } & \text { Application Programming Interface } \\ \text { AV } & \text { Ambiente Virtual } \\ \text { RS } & \text { Revisão Sistemática } \\ \text { RV } & \text { Realidade Virtual } \\ \text { ViMeT } & \text { Virtual Medical Training }\end{array}$


Lista de símbolos

$\Delta \quad$ Letra grega Delta 


\section{Sumário}

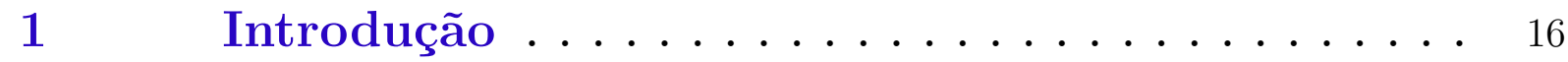

$1.1 \quad$ Motivação . . . . . . . . . . . . . . . . . . 17

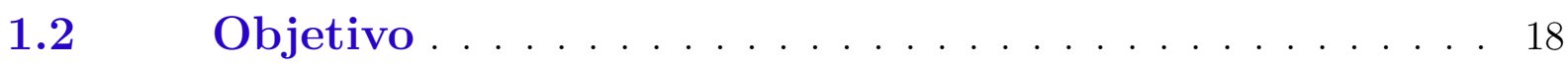

1.3 Organização do documento . . . . . . . . . . . . . . 19

2 Conceitos Fundamentais . . . . . . . . . . 20

$2.1 \quad$ Exame de palpação . . . . . . . . . . . . . . . 20

2.1.1 Educação e treinamento do exame . . . . . . . . . . . . . 22

2.1.2 Características dos nódulos malignos e benignos . . . . . 24

$2.2 \quad$ Realidade Virtual . . . . . . . . . . . . . . . . . 26

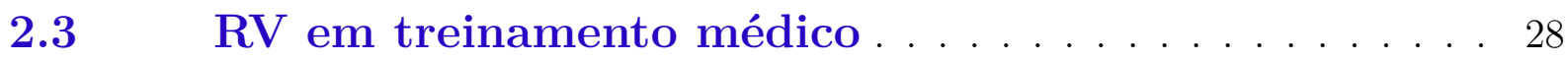

2.4 Interação háptica . . . . . . . . . . . . . . . . . . . . . . . 29

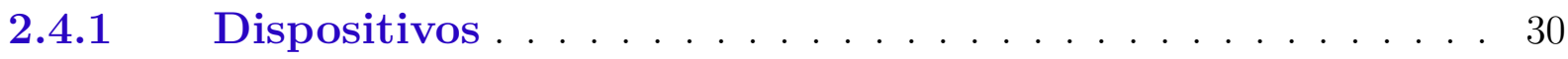

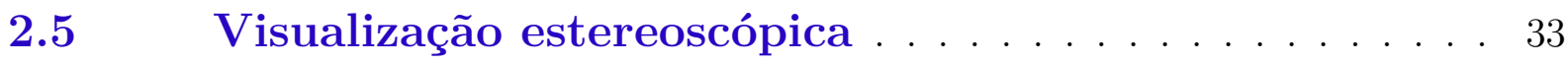

3 Simulação de exames de palpação com retorno háptico....................... 35

3.1 Planejamento e Condução . . . . . . . . . . . 35

3.1.1 Planejamento . . . . . . . . . . . . . . . 36

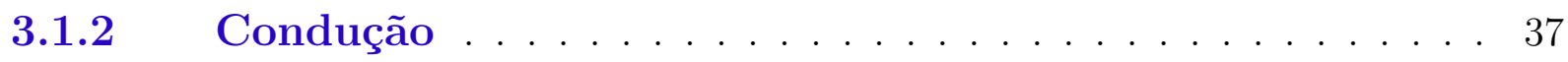

3.2 Análise quantitativa dos trabalhos incluídos . . . . . . 38

3.3 Áreas de aplicação contempladas . . . . . . . . . . . . . 40

3.3.1 Palpação cirúrgica . . . . . . . . . . . . . . . . . . . 41

3.3.2 Palpação para detecção de câncer . . . . . . . . . . . 42

3.3.3 Radiologia intervencional . . . . . . . . . . . . . . 44

3.3.4 Medicina osteopática e fisioterapia . . . . . . . . . . 45

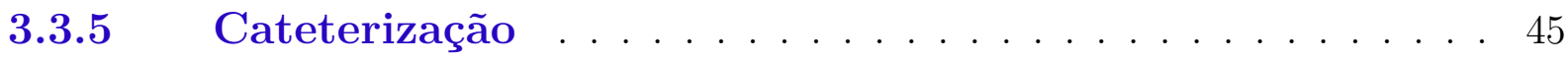

3.3.6 Palpação arterial . . . . . . . . . . . . . . . . 46

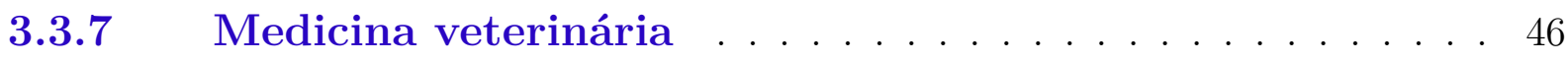

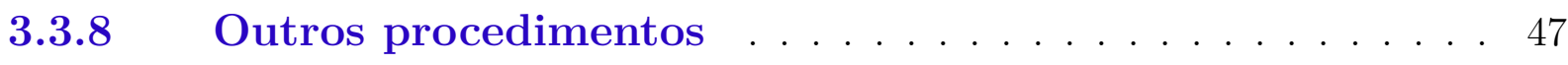

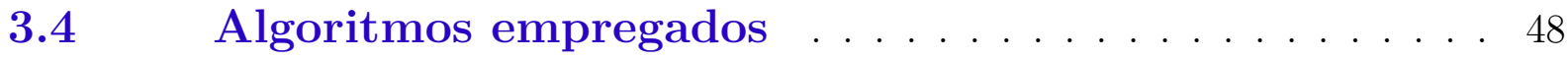


3.4.1 Método de Elementos Finitos . . . . . . . . . . . . . . . 49

3.4.2 Método Massa-mola . . . . . . . . . . . . . . . . . . . . 50

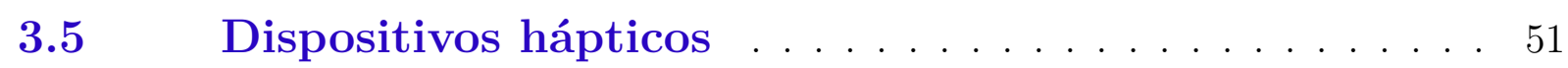

3.5.1 Dispositivo Phantom . . . . . . . . . . . . . . 51

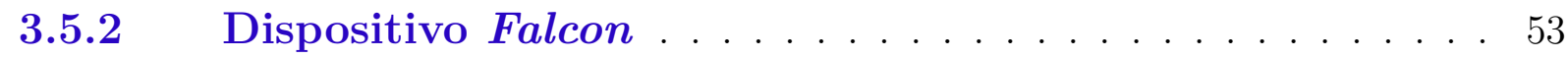

3.5.3 Dispositivos e técnicas de visualização . . . . . . . . . 53

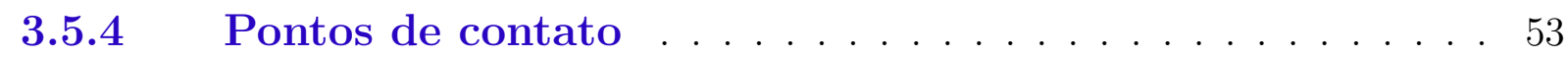

3.6 Discussão sobre os trabalhos incluídos . . . . . . . . . . 54

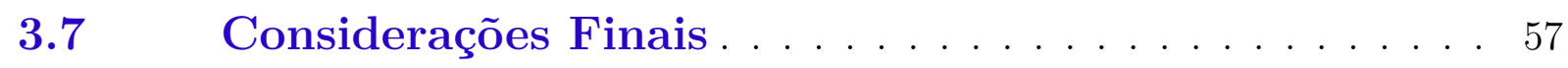

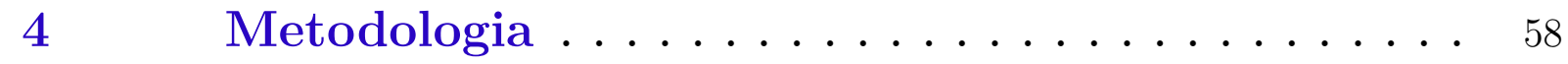

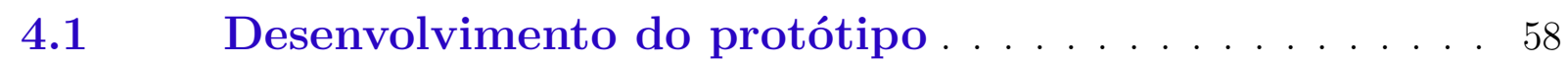

4.1.1 Dispositivo háptico e modelagem de objetos . . . . . . . 58

4.1.2 Pesquisa e definição dos parâmetros . . . . . . . . . . . 61

4.1.2.1 Implementação e interação . . . . . . . . . . . . . . . . . . . . . . 64

4.2 Versão final do simulador de palpação mamária . . . . . 67

4.2.1 Adaptação do dispositivo háptico . . . . . . . . . . . . 68

4.2.2 Modelagem dos objetos . . . . . . . . . . . . . . . . 69

4.2.3 Implementação dos parâmetros de retorno de força do nódulo . . . . . . . . . . . . . . . . . . . . . . 70

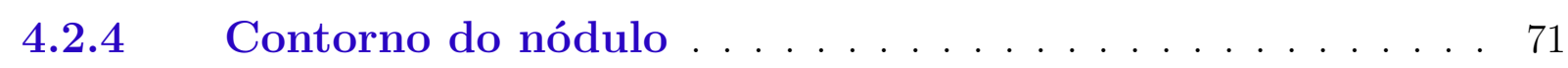

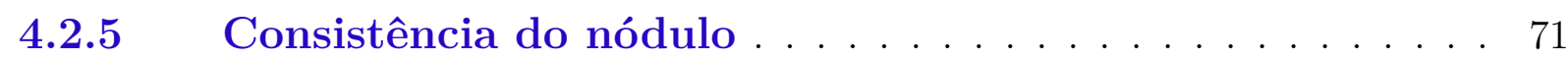

4.2.6 Tamanho do nódulo . . . . . . . . . . . . . . . . . 72

4.2.7 Posição do nódulo na mama . . . . . . . . . . . . . . 72

4.2.8 Mobilidade do nódulo . . . . . . . . . . . . . . . . . 74

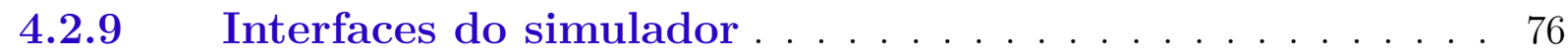

$5 \quad$ Resultados e Discussões . . . . . . . . . . . . . 80

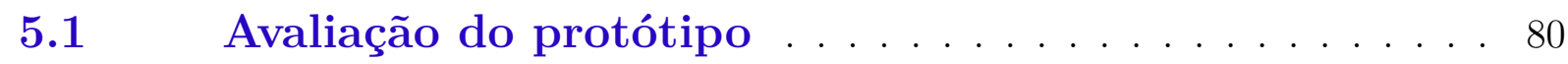

5.2 Avaliação da versão final do simulador . . . . . . . . . . 85

5.2.1 Consistência do nódulo . . . . . . . . . . . . . . . . 85

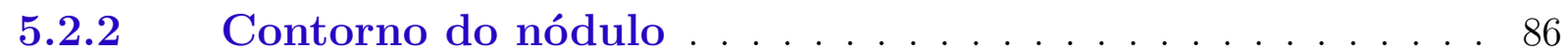

5.2.3 Tamanho do nódulo . . . . . . . . . . . . . . . . 87 
5.2.4 Localização do nódulo . . . . . . . . . . . . . . . . 87

5.2.5 Mobilidade do nódulo . . . . . . . . . . . . . . 87

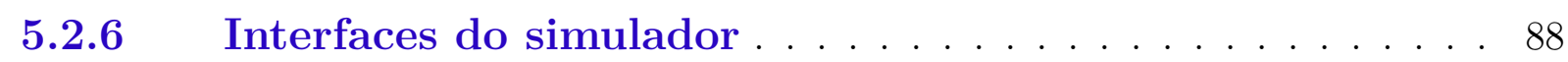

5.2.7 Considerações adicionais sobre a avaliação . . . . . . . . 88

$6 \quad$ Conclusões . . . . . . . . . . . . . . . . . 90

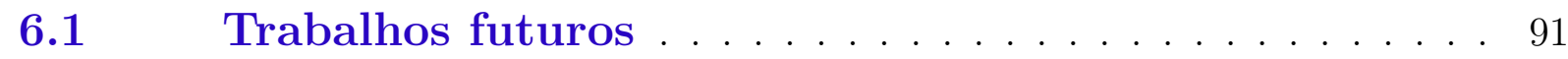

6.2 Artigos publicados e submetidos . . . . . . . . . 92

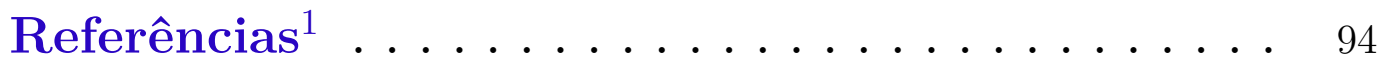

Apêndice A-Protocolo de Revisão Sistemática . 105

Apêndice B-Tabela de artigos incluídos na Revisão Sistemática . . . . . . . . . . 108 


\section{Introdução}

A Realidade Virtual (RV) é uma forma de interface homem-máquina que permite a criação de mundo virtuais ou artificiais com o uso de alta tecnologia para convencer o usuário de que ele se encontra em um ambiente próximo do real (MONTERO; ZANCHET, 2003). Sua utilização, quando empregada no âmbito de treinamento médico, oferece uma forma de aprendizado diferenciada, devido à maior interatividade em tempo real, a qual pode oferecer uma simulação mais real (OLIVEIRA; NUNES, 2010). Aplicações que utilizam RV são oportunas para a construção de ferramentas de treinamento, pois podem oferecer a interação em um Ambiente Virtual (AV), por meio de dispositivos convencionais e não convencionais (NUNES et al., 2011). A adoção de aplicações de RV que dispõem de simulação com retorno háptico pode oferecer aos profissionais da área de saúde um complemento às situações encontradas no ambiente real, assim como um treinamento aos estudantes que ainda não vivenciaram a prática dos procedimentos em questão.

A palpação mamária é uma das principais formas de exame para prevenir o câncer (PETRIE; THOMAS, 2007). Consiste na investigação sistemática do tecido mamário por um clínico profissional, por meio do toque, em busca de nódulos rígidos e irregulares. Durante o procedimento, o profissional da saúde pressiona uma área de interesse com seus dedos para localizar pontos abaixo da pele do paciente e sentir a presença ou ausência de características ou anormalidades anatômicas (COLES; MEGLAN; JOHN, 2011).

McDonald, Saslow e Alciati (2004) mencionam algumas das abordagens utilizadas para o ensino do exame de palpação mamária, como aulas, experimentos práticos utilizando modelos de mama de silicone e exames em pacientes humanos com o acompanhamento de profissionais. Apesar de tais abordagens serem comuns nas escolas, Kotranza, Lind e Lok (2012) afirmam que elas não tratam alguns dos principais obstáculos para atingir um bom nível de competência, como a comunicação com o paciente e a falta de habilidade para balancear as tarefas psicomotoras e cognitivas. Aliada a estes obstáculos, está a ausência de oportunidades para treinamento e avaliação adequados, que culminam em um nível alto de ansiedade e falta de confiança nos estudantes (MADAN et al., 2002), (PUGH; SALUD, 2007). Tais afirmações são corroboradas por Kann e Lane (1998), que conduziram um estudo no qual $83 \%$ de estudantes do quarto ano de medicina reportaram a necessidade de treinamento adicional para o exame de palpação da mama. Além disso, muitos profissionais mostram baixa confiança em suas habilidades de exames de palpação de mama (GERLING 
et al., 2003) e vários residentes, enfermeiras e médicos expressam desejos de melhorar sua competência para este exame (WIECHA; GANN, 1993).

A partir das premissas apresentadas, o desenvolvimento de sistemas virtuais que ofereçam retorno de força, possam ser modificados dinamicamente e não sofram desgastes em decorrência do uso, é bastante encorajado. Isto se dá pelo fato de que tais sistemas podem oferecer um nível de realismo capaz de proporcionar um treinamento com maior acurácia e aprendizado por parte dos seus utilizadores.

\subsection{Motivação}

Nos últimos anos, a simulação de palpação vem assumindo um papel de destaque nos trabalhos da área de RV em Medicina, visto que o número de trabalhos do segmento é crescente. Isto se deve ao fato de que o exame de palpação é um dos principais para o diagnóstico inicial de várias doenças, e, por isso, é empregado em simuladores de diferentes competências médicas, ainda que compartilhem do mesmo propósito.

Okamura et al. (2011) ressaltam o papel dos sistemas hápticos, afirmando que as interações hápticas podem auxiliar no treinamento e na avaliação de aquisição de habilidades clínicas, incluindo cirurgias, intervenção radiológica, anestesiologia, odontologia, medicina veterinária, entre outros procedimentos ou áreas. A palpação está presente na maioria destes procedimentos clínicos; portanto, é uma competência que pode ser treinada por meio de interfaces hápticas, em diferentes áreas.

Tani et al. (2004) destacam a importância da habilidade sensorial na execução de movimentos, uma vez que ela é considerada como parâmetro referencial para a memória humana em processos contínuos e sequenciados de ações, ou seja, o treinamento do procedimento de palpação no mundo virtual permite a transferência do conhecimento adquirido para o mundo real, aperfeiçoando as habilidades do indivíduo.

Uma revisão sistemática conduzida e apresentada no presente documento (Capítulo 3) mostrou que, embora tenham sido desenvolvidos muitos trabalhos, ainda não existe uma definição concreta a respeito dos parâmetros mais realistas de retorno de força para simulação. Isso significa que a sensação de toque oferecida para cada dedo durante o uso de uma determinada ferramenta pode não ser considerada ideal, especialmente para os três dedos utilizados na realização do procedimento - indicador, médio e anelar. 
Esta é uma grande lacuna e a principal motivação deste trabalho, pois a delimitação correta dos parâmetros mais realistas de retorno para o treinamento virtual certamente auxiliará o aperfeiçoamento das habilidades dos profissionais na realização do exame, complementando os conhecimentos obtidos em sala e em atividades práticas. Isto é corroborado por Schubart et al. (2012), que menciona que o uso de um simulador de palpação que utiliza nódulos pulsantes (balões infláveis inseridos dentro de um modelo de silicone para simular nódulos mamários (GERLING; THOMAS, 2005), em vez de um modelo com nódulos estáticos, fez com que estudantes apresentassem um aprimoramento da capacidade de detecção de nódulos.

\subsection{Objetivo}

Este projeto tem como objetivo geral o desenvolvimento de um sistema de RV que usa um dispositivo háptico para o treinamento de exame de palpação mamária com retorno háptico realista. Em especial, pretende-se obter a definição dos parâmetros de retorno de força corretos para a simulação deste procedimento, buscando aumentar o realismo do treinamento virtual e, consequentemente, oferecer uma ferramenta que auxilie no aprimoramento das habilidades do aprendiz na execução do procedimento.

A partir de estudos das técnicas e parâmetros adotados nos trabalhos para a construção do simulador, busca-se deixar como principal contribuição para a área de Computação, a definição das técnicas e parâmetros que proporcionem realismo durante a realização de uma simulação do exame de palpação.

São objetivos específicos do trabalho de Mestrado proposto:

- definição de técnicas e parâmetros de retorno de força para simular o procedimento com realismo;

- definição de equacionamento adequado para representar os parâmetros como força retornada ao usuário ao utilizar um dispositivo háptico;

- implementação das interfaces do simulador com a finalidade de permitir a criação de casos de estudos com parâmetros variados;

- validação do simulador virtual com profissional da área de saúde. 


\subsection{Organização do documento}

Além deste capítulo introdutório, o presente documento está organizado da seguinte forma:

- Capítulo 2: apresenta os conceitos fundamentais para compreensão do trabalho, incluindo exame de palpação e treinamento; características dos nódulos benignos e malignos; RV e sua aplicação em treinamento médico; interação háptica, assim como os dispositivos utilizados nela e visualização esteroscópica.

- Capítulo 3: é apresenta e discute a revisão bibliográfica sistemática conduzida sobre exames de palpação com retorno háptico, bem como os resultados obtidos por meio dela;

- Capítulo 4: disponibiliza a metodologia utilizada no trabalho de Mestrado, descrevendo os detalhes pertinentes ao desenvolvimento do protótipo e do simulador de palpação, especialmente no que concerne às características selecionadas e os parâmetros implementados para simulação destas.

- Capítulo 5: apresenta os resultados obtidos a partir da avaliação do simulador desenvolvido e uma discussão acerca deles;

- Capítulo 6: são apresentadas as conclusões deste trabalho;

Em seguida estão as referências que serviram como embasamento teórico para a elaboração desta dissertação e os apêndices A e B que, respectivamente, apresentam o protocolo de Revisão Sistemática (RS) e uma tabela com os artigos incluídos na RS. 


\section{Conceitos Fundamentais}

O presente capítulo faz uma síntese dos principais conceitos que se relacionam ao trabalho apresentado neste documento. Na Seção 2.1 é apresentada uma explicação sobre o exame de palpação, com ênfase em palpação mamária, detalhando a realização do procedimento e as características procuradas por um profissional que auxiliam na detecção de possíveis anormalidades no local em questão. Na Seção 2.2 são expostos os principais aspectos conceituais sobre os sistemas de RV. Na seção 2.3 é detalhado o papel da RV na área de treinamento médico, principalmente em simuladores de palpação com retorno háptico. Na seção 2.4 são apresentados os aspectos conceituais da interação háptica.

\subsection{Exame de palpação}

A palpação é um passo importante do processo de diagnóstico de muitas doenças, pois contribui para a detecção de nódulos, hérnias e anomalias em movimentos de certas partes do corpo humano, como coração, pulmões, intestinos e músculos. Consiste em um procedimento no qual o profissional da saúde pressiona uma área de interesse com seus dedos para localizar pontos abaixo da pele do paciente e sentir a presença ou ausência de características ou anormalidades anatômicas (COLES; MEGLAN; JOHN, 2011). A palpação é considerada uma forma efetiva, sensível e econômica para detectar diversas disfunções do corpo (WILLIAMS II et al., 2004). Na Figura 1 pode-se observar uma demonstração da palpação abdominal.

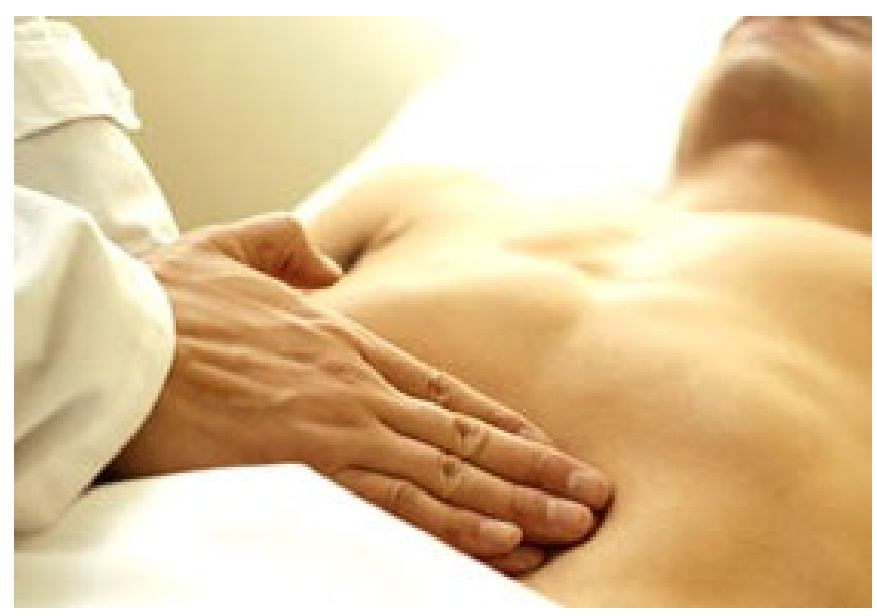

Figura 1 - Palpação abdominal

Fonte: (TORRIERI, 2015) 
Entretanto, Williams II et al. (2004) lembram que a palpação é difícil de aprender devido a três motivos:

1. requer um senso de toque altamente treinado;

2. estudantes, na sua maioria, praticam entre eles, os quais geralmente são pessoas jovens;

3. sucessivas palpações em um sujeito podem provocar alterações no corpo, propiciando experiências diferentes para um mesmo caso.

O exame de palpação de mama, que é a investigação sistemática do tecido mamário por um clínico profissional, por meio do toque, em busca de nódulos rígidos e irregulares, é uma das principais formas de exame para prevenir o câncer (PETRIE; THOMAS, 2007). Na Figura 2 é exibida uma imagem do exame de palpação da mama executada em um manequim.

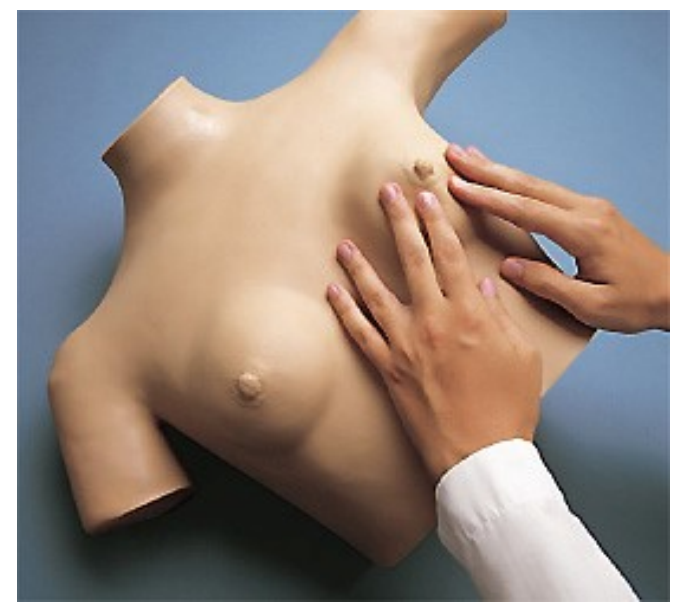

Figura 2 - Palpação da mama

Fonte: (CIVIAM, 2015)

Durante a palpação, nódulos que são discretos e diferem do tecido ao redor podem ser identificados. Estes nódulos podem se movimentar dentro do tecido ou mesmo serem perceptíveis devido a alterações na pele. Descobertas mais sutis podem ter interpretação mais complicada. Tais descobertas podem incluir áreas que não se movem ou comprimem como esperado ou que são assimétricas em relação à outra mama, como espessamento assimétrico de tecido da mama ou leve assimetria do contorno da mama (MCDONALD; SASLOW; ALCIATI, 2004).

Estudos descritivos constantemente indicam que a palpação de linfonodos deve se estender acima e abaixo das clavículas e axilas (lateral, central, subescapular, peito- 
ral), e que a palpação de linfonodos deve ser realizada enquanto a mulher está sentada (MCDONALD; SASLOW; ALCIATI, 2004).

\subsubsection{Educação e treinamento do exame}

Bryan e Snyder (2013) afirmam que as abordagens educacionais ideais para treinamento do exame de palpação incluem o uso de simulações aliado à exposição a pacientes. O mesmo estudo afirma que estudantes que participaram de um treinamento cujo currículo era bem estruturado, incluindo lições didáticas, prática com simulação (com modelos de silicone ou virtual) e com pacientes, apresentaram maior proficiência na tarefa de identificação de características anormais da mama em modelos de silicone do que estudantes que não tiveram um treinamento bem estruturado.

Alguns dos modelos físicos utilizados para treinamento apresentados em Bryan e Snyder (2013) são:

- Kyoto breast task trainer (Figura 3): simulador que auxilia no treinamento para diferenciação de quatro nódulos mamários típicos.

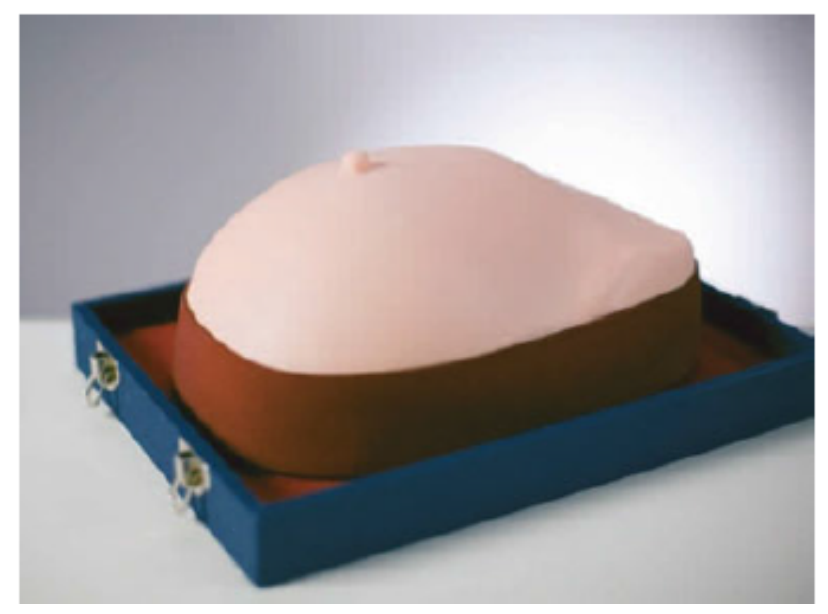

Figura 3 - Kyoto breast task trainer

Fonte: (BRYAN; SNYDER, 2013)

- Gaumard breast task trainer (Figura 4): modelo que apresenta as mamas esquerda e direita, conectadas a um tronco adulto. A mama esquerda apresenta patologias para autoexame, e a direita para treinamento de palpação; 


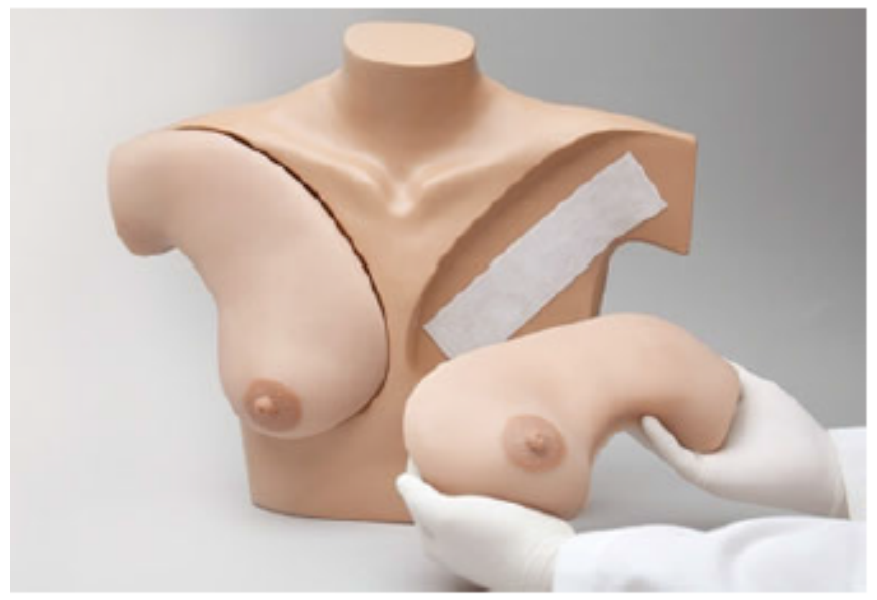

Figura 4-Gaumard breast task trainer

Fonte: (BRYAN; SNYDER, 2013)

- MammaCare CBE simulation training (Figura 5): simulador que inclui quatro tipos de mama e um computador portátil e emula protocolos de exame de palpação, os quais consistem em uma serie de módulos de treinamento para detectar descobertas anormais na mama.

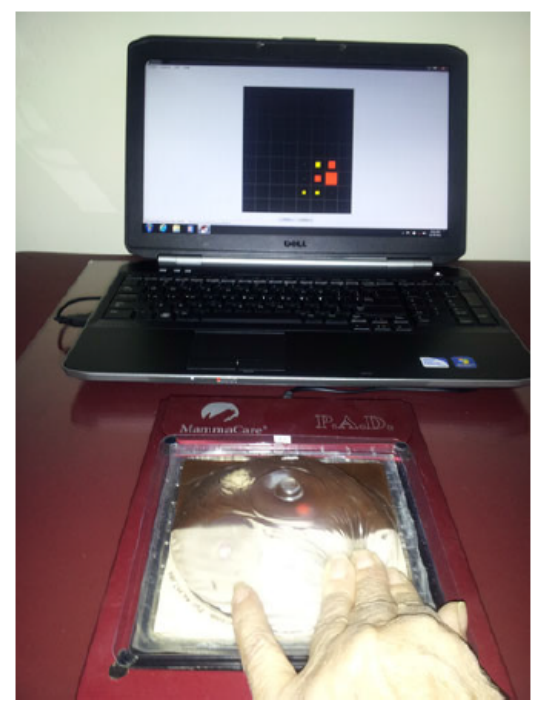

Figura 5 - MammaCare CBE simulation training

Fonte: (BRYAN; SNYDER, 2013)

As sessões práticas com pacientes simulados e clínicos constituem um padrão utilizado para ensino do exame de palpação há vários anos (SCHUBART et al., 2012). O fato de os pacientes simulados não apresentarem sinais clínicos e pacientes clínicos apresentarem sinais imprevisíveis, podem fazer com que as sessões práticas sejam experiências 
educacionais inconsistentes para os estudantes, pois eles podem não saber compreender tais sinais.

As sessões práticas com pacientes reais como primeira forma de exposição do exame de palpação aos estudantes podem contribuir para um ambiente de aprendizado com qualidade abaixo do esperado, devido ao desconforto inerente à natureza íntima do exame. Tal desconforto pode comprometer a capacidade de aprendizado dos estudantes (SCHUBART et al., 2012).

O estudo de Schubart et al. (2012) procurou comparar o aprendizado do exame no simulador com o aprendizado com sessões em pacientes humanos, com a finalidade de avaliar a aquisição de habilidades e nível de conforto para realização do exame. A conclusão foi que os estudantes que utilizaram o simulador apresentaram um desempenho melhor ou tão bom quanto o dos que aprenderam nos pacientes, ainda que o benefício estivesse limitado a estudantes de menor experiência.

\subsubsection{Características dos nódulos malignos e benignos}

As modificações que ocorrem na mama das mulheres no decorrer das suas vidas fazem com que o limite da normalidade no tecido mamário seja difícil de ser definido (INCA, 2015).

Por isso, originou-se o conceito de alterações funcionais benignas da mama, às quais previamente eram atribuídas as denominações de doença fibrocística ou displasia mamária. Do ponto de vista clínico, tais vocábulos têm sido associados a uma condição na qual são identificadas alterações na palpação, que podem ou não envolver dor e maior sensibilidade. Algumas irregularidades que ocorrem na maioria das mulheres podem ser confundidas com nódulos malignos durante o exame de palpação (INCA, 2015), como cisto mamário, fibroadenoma, processos inflamátórios e densidades assimétricas.

O nódulo relacionado com malignidade, por sua vez, apresenta uma variedade de sinais diretos e indiretos que podem indicar sua ocorrência. Em geral, esses nódulos apresentam contorno espiculado ou irregular (RAHBAR et al., 1999). No caso de um nódulo cujo contorno é bem definido e redondo, geralmente tal característica representa um indício de benignidade (RAHBAR et al., 1999).

No trabalho de Almeida, Jorge e Cecatti (2012) foram avaliadas a sensibilidade e a especificidade, além de valores preditivos positivo e negativo do exame de palpação da 
mama no diagnóstico diferencial entre benignidade e malignidade dos nódulos mamários. O exame clínico conduzido com vários indivíduos levou à classificação dos nódulos em duas categorias distintas: benignos ou provavelmente benignos e malignos ou provavelmente malignos. Os classificados na primeira categoria apresentaram algumas ou todas as seguintes características: limites bem definidos, consistência fibro-elástica; não adesão ao plano superficial ou profundo (móvel); pele e papila mamária sem alterações. Os malignos ou provavelmente malignos mostraram algumas ou todas as seguintes características: limites mal definidos, consistência pétrea, adesão a plano superficial ou profundo; retração da pele ou papila, desvio e edema da pele adjacente.

Em Silva e Oliveira (2010) são apresentadas ponderações a respeito do procedimento que deve ser seguido para palpação da mama à procura de nódulos. A localização de um eventual nódulo mamário deve ser referenciada à mama direita e/ou esquerda, bem como aos quadrantes superiores (interno e externo) e inferiores (interno e externo). O nódulo pode estar localizado na junção de dois quadrantes ou, ainda, localizado no centro ou na região retroareolar. Em algumas situações, o nódulo pode confundir-se com uma adenopatia axilar ${ }^{1}$, quando se localiza no prolongamento axilar da mama.

Conforme abordado anteriormente, algumas características constituem importantes aspectos a serem observados durante o exame de palpação e podem auxiliar na definição de um diagnóstico inicial assertivo:

- Consistência: pode ser considerada fibroelástica, cística ou endurecida. É fundamental também avaliar a mobilidade do nódulo e a sua aderência ou não ao plano muscular profundo e/ou à pele (SILVA; OLIVEIRA, 2010).

- Forma: de acordo com Nazário e Rego (2007), as seguintes formas do nódulo são perceptíveis para o profissional durante a realização do exame clínico da mama: redonda (um nódulo que é esférico, em forma de bola, circular ou em forma de globo), elipsóide (um nódulo que é elíptico ou em forma de ovo) e lobulado (um nódulo que tem contornos com ondulações).

- Contorno: de acordo com Azevedo et al. (2009), o contorno do nódulo constitui a característica mais importante e perceptível para o profissional conduzindo o exame. Ainda que as margens não sigam padrões exatos de benignidade e malignidade, são destacados dois tipos de formação das margens dos nódulos que auxiliam no

1 A adenopatia axilar é o aumento do volume de um ou mais dos gânglios linfáticos situados no nível das axilas (SAÚDE, 2015). 
diagnóstico e classificação dos nódulos: redondo, no qual o nódulo apresenta limites bem definidos, sem irregularidades em sua superfície; e espiculado, no qual o nódulo tem limites mal definidos e irregularidades na sua superfície.

- Aderência: o nódulo pode ser aderido tanto ao plano superficial quando ao plano profundo da mama. Esta aderência é um indicativo de malignidade. Por outro lado, o nódulo pode apresentar uma maior mobilidade, isto é, quando pressionado, tem uma tendência maior a movimentar-se na mama. Isto, por sua vez, pode representar um indício de benignidade (ALMEIDA; JORGE; CECATTI, 2012).

- Tamanho: Os exames clínicos realizados por Almeida, Jorge e Cecatti (2012) mostraram que o diâmetro médio dos nódulos encontrados foi de $2,56 \mathrm{~cm}$, sendo semelhante nos dois grupos (2,72cm nas benignas e 2,49 nas malignas). O diâmetro do menor nódulo maligno estudado foi de $1,0 \mathrm{~cm}$ e o maior de $4,0 \mathrm{~cm}$. No grupo com doença benigna, esta variação ficou entre 1,0 e 7,8cm. Durante a palpação mamária usa-se um compasso ou uma pequena régua para medir os diâmetros do nódulo. São tomadas medições em duas dimensões sendo mais importante a maior delas. Por vezes, pode ser identificado mais do que um nódulo, no mesmo quadrante ou em quadrantes diferentes (SILVA; OLIVEIRA, 2010).

De acordo com Hegg (2000), de maneira geral, quanto maior for o tamanho do nódulo primário, pior será o prognóstico da paciente. O carcinoma medular da mama faz exceção a essa regra, pois, embora frequentemente seja um nódulo de grande tamanho, tem um bom prognóstico.

O carcinoma da mama, de modo geral, só pode ser palpado clinicamente quando tiver um diâmetro acima de um centímetro. O câncer mínimo da mama é um carcinoma com diâmetro menor do que meio centímetro e altamente curável (GALLAGER; MARTIN, 1969). Os nódulos com tamanho menor do que dois centímetros também apresentam um bom prognóstico, pois o tamanho médio dos cânceres detectados no autoexame é maior do que dois centímetros (GALLAGER; MARTIN, 1969).

\section{$2.2 \quad$ Realidade Virtual}

Burdea e Coiffet (2003) definem RV como um processo de simulação em que a computação gráfica é utilizada para criar um mundo de aparência realista e que possibilite 
a interatividade em tempo real. A RV envolve a geração de ambientes tridimensionais, a partir de um computador e um conjunto de ferramentas de interface que ofereçam imersão, navegação e interação com objetos no AV (GREENLEAF, 2004).

Existem na literatura várias outras definições para Realidade Virtual. A RV pode ser definida como um ambiente sintético ou virtual, que oferece ao usuário um senso de realidade, ou seja, uma sensação de "estar presente" (NUNES, 2014).

Basicamente, a RV fornece auxílio à construção de ambientes sintéticos com características próximas das do mundo real, tornando as aplicações propícias para treinamento e simulação. Estas aplicações possibilitam a interação e a manipulação dos objetos no $\mathrm{AV}$, assim como a navegação dentro do ambiente. Estas características funcionam como motivação para que pesquisadores desenvolvam aplicações de RV para treinamento médico (OLIVEIRA; NUNES; BEZERRA, 2007).

A RV consiste em uma área de pesquisa que engloba conhecimento de diversas áreas: computação, eletrônica, robótica e cognição, de forma a oferecer sistemas computacionais que integram características de imersão e interatividade. A partir disto, busca-se simular ambientes reais onde os usuários estimulam seus sentidos pelo uso de dispositivos específicos (MORAES; MACHADO; SOUZA, 2003).

Nunes e Costa (2008) destacam três aspectos desejáveis em RV: imersão, que propicia ao usuário a sensação de estar dentro do AV; interação, que consiste na comunicação satisfatória entre usuário e aplicação; e presença, que consiste na sensação de envolvimento por parte do usuário junto à aplicação. Em várias aplicações para saúde, a presença é fundamental para que o usuário envolva-se no ambiente. Para envolver o usuário proporcionando a sensação de presença em aplicações na área de saúde em relação à qualidade dos objetos tridimensionais e sua correlação espacial, e ao controle realista da interação, que deve permitir o uso simultâneo de diversos dispositivos e favorecer os aspectos ergonômicos da aplicação.

No contexto da área médica, Machado (2003) afirmou que a utilização das ferramentas de RV para treinamento médico pode oferecer uma nova forma de aprendizado, no qual imagens tridimensionais, exploração interativa e informações táteis formam uma combinação que pode fornecer uma simulação cada vez mais realista.

Neste sentido, o uso da tecnologia de RV em aplicações que dispõem de simulação com retorno háptico, permite oferecer uma forma de treinamento que agrega conhecimento de forma rápida e interativa. Também é possível citar outras razões para adotar ambientes 
de simulação, como questões éticas, segurança do paciente e planejamento pré-operatório antes da realização de um procedimento (CHOI et al., 2002).

\subsection{RV em treinamento médico}

Na área de saúde, as aulas práticas são essenciais para o aprendizado de procedimentos médicos e clínicos, pois procedimentos mal executados podem resultar em consequências graves para os pacientes. Nesse contexto, a utilização de simulações para o treinamento destes procedimentos se mostra cada vez mais crescente (KORMOS et al., 2013).

Tal prática prepara estudantes, técnica e psicologicamente, para desenvolverem tarefas reais. Além disso, podem auxiliar o processo educacional em diferentes faixas etárias, oferecer a profissionais meios de treinar novas técnicas simulando diferentes situações genéricas (desassociadas das peculiaridades de uma situação ideal), assim como facilitar o ensino de hábitos a pacientes (NUNES et al., 2011).

Nunes et al. (2011) afirmam que o objetivo geral dos simuladores de RV é permitir a prática de técnicas em ambientes que imitam a realidade de um procedimento ou criam situações hipotéticas para explicar ou ensinar algum conceito. Alguns dos recursos oferecidos por sistemas dessa natureza são a visualização estereoscópica (visualização que propicia a sensação de profundidade nos AVs) ou algum tipo de retorno (tátil, visual ou auditivo) às interações do usuário. Tais recursos aumentam a imersão dos usuários e tornam mais realista a interação, influenciando positivamente sua capacidade de aprendizado. Os jogos também têm sido utilizados neste contexto, de forma a favorecer uma maior motivação para o aprendizado de conteúdos (MACHADO et al., 2011).

O aumento da adesão às ferramentas de RV está diretamente relacionado aos benefícios proporcionados por tais sistemas, como: redução de riscos aos pacientes (COLES; MEGLAN; JOHN, 2011), elevação da segurança por parte dos aprendizes (LAMBDEN; MARTIN, 2011) e possibilidade de executar avaliações automatizadas de desempenho (ANJOS; NUNES; TORI, 2012).

Adicionalmente aos benefícios citados, as tecnologias de RV permitem contemplar diversos níveis de treinamento, com diferentes situações e graus de dificuldade (ULLRICH; KUHLEN, 2012) e podem minimizar ou eliminar custos que envolvem a manutenção de laboratórios físicos, com infraestrutura constituída por cadáveres ou animais (GOMOLL et 
al., 2007). Embora ofereçam a presença física, cadáveres apresentam diferenças fisiológicas em relação ao corpo humano in vivo (JAUNG; COOK; BLYTH, 2011); os animais por sua vez, apresentam divergências na anatomia em relação aos seres humanos (ABOUD et al., 2004). Por fim, a utilização de ambos no treinamento, envolve questões éticas (COLES; MEGLAN; JOHN, 2011).

Outros benefícios de RV no treinamento consistem na repetição do treinamento em um número considerável de vezes sem o desgaste de materiais, como ocorre na utilização de cadáveres, por exemplo (GRECHENIG et al., 1999); e na flexibilidade, principalmente dos modelos, visto que determinados objetos tangíveis, como manequins, geralmente possibilitam a presença física, no entanto, incluem limitações que envolvem a replicação da fisiologia e a variação anatômica (COLES; MEGLAN; JOHN, 2011).

A importância do tradicional uso de cadáveres e animais é evidente (STEFANIDIS et al., 2013), entretanto, tecnologias como as de RV podem ser consideradas como um complemento no treinamento (WILLIS et al., 2014), principalmente as tecnologias que permitem a interação háptica (VÅPENSTAD et al., 2013). As modalidades sensoriais humanas comumente exploradas nas simulações médicas são ordenadamente, visual e tátil, seguidas a uma grande distância pela auditiva, e por último e quase inexistentes, pelas olfativa e gustativa (COLES; MEGLAN; JOHN, 2011).

\subsection{Interação háptica}

O termo háptico relaciona-se ao tato (do grego haptikós - sensível ao tato), ou seja, significa tátil. Mais recentemente, cunhou-se em inglês o substantivo haptics (em português traduzido como "háptica") para designar a ciência do toque dedicada a estudar e a simular a pressão, a textura, a vibração e outras sensações biológicas relacionadas com o toque.

O toque consiste de uma sensação quando a pele é submetida a estímulos mecânicos, elétricos, térmicos ou químicos (BURDEA, 1996). Esta sensação pode ser dividida em senso háptico e controle sensório-motor. No que diz respeito ao senso háptico, leva-se em consideração o tato, que consiste em um conjunto de eventos que se iniciam com estímulos sobre a pele, tais como pressão ou vibração, os quais são captados por receptores (termoreceptores, receptores mecânicos, entre outros). Em seguida, descargas elétricas são geradas e transmitidas ao cérebro pelos nervos que, por sua vez, registra a sensação (BURDEA, 1996). 
O senso do toque envolve muitos tipos de receptores na pele que detectam níveis variados de pressão, vibração, temperatura e dor. Relacionada ao toque está a cinestesia, um sentido que permite detectar a posição e o movimento do corpo no espaço, assim como as suas tensões internas. Quando um indivíduo entra em contato com o ambiente e manipula-o, o senso de toque e cinestesia estão altamente entrelaçados (ADAMS; HANNAFORD, 1999).

O controle sensório-motor está ligado ao fato de que os seres humanos combinam o senso de posição e cinestesia, ou seja, postura e movimentos, para exercer um controle motor durante uma atividade (BURDEA, 1996).

Segundo Burdea (1996), quando se discute a geração de força e a sensação tátil, alguns conceitos devem ser levados em conta, como:

- feedback tátil: sensação aplicada às terminações nervosas da pele que indica alguma sensação;

- feedback de força: retorno de sensação de peso ou resistência de algo;

- feedback cinestésico: percepção de movimentos por órgãos existentes em músculos, tendões, juntas;

- feedback proprioceptivo: movimentos definidos por informações oferecidas de acordo com a postura (juntas do esqueleto).

\subsubsection{Dispositivos}

Os dispositivos de tato e força são chamados de interfaces hápticas (haptic interfaces) e representam o estudo de como acoplar o sentido do tato humano a um mundo gerado em computador. Assim como um dispositivo de vídeo permite que o usuário possa ver uma cena gerada por um computador, um dispositivo háptico permite que o usuário possa senti-la. As funções de um dispositivo variam de acordo com os receptores de pele que eles buscam estimular. Dispositivos táteis, uma subclasse de dispositivos hápticos, estimulam a vibração e a pressão, enquanto outros dispositivos geram outros movimentos e forças que são sentidos pelo toque e cinestesia (ADAMS; HANNAFORD, 1999).

Estes dispositivos também são denominados como não convencionais e podem ser acoplados aos sistemas de RV a fim de oferecer uma interação mais próxima da realidade. Alguns exemplos são as luvas de dados, capacetes, óculos estereoscópicos, equipamentos hápticos, sensores corporais, entre outros. Os dispositivos hápticos são desejáveis em várias 
aplicações de RV, uma vez que a interação homem-máquina em AVs é promovida por meio de interfaces intuitivas (KIM et al., 2002).

Com um equipamento háptico, o usuário tem a possibilidade de utilizar o senso de toque para enviar e receber informações do computador, pois o dispositivo é movimentado pelo usuário e pode produzir um retorno de força na superfície da sua pele (OAKLEY et al., 2000). Como exemplo de informação sobre o ambiente fornecida ao usuário durante a interação, tem-se o sentimento de textura e peso de objetos, podendo haver ou não uma integração com estímulos sonoros e visuais (RIEDER et al., 2006). Na Figura 6 é exibido o dispositivo háptico Phantom Omni.

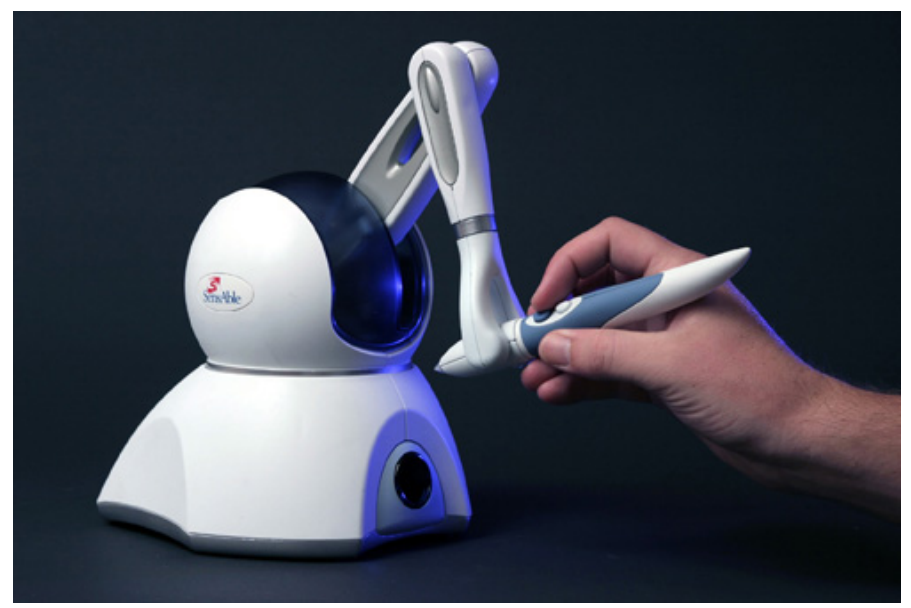

Figura 6 - PHANTOM Omni

Fonte: (GEOMAGIC, 2015)

Os dispositivos hápticos podem ser subdivididos em (BARILLI; EBECKEN; CUNHA, 2011):

- dispositivos de resposta tátil (tactile feedback): são os dispositivos que provêm a interação com as terminações nervosas da pele que indicam a forma, calor e textura. A sensação de tato provê informações sobre a geometria da superfície, sua textura ou sua temperatura.

- dispositivos de força ou pressão (force feedback): são dispositivos que interagem com os músculos e os tendões, oferecendo ao ser humano uma sensação de aplicação de uma força em sentido contrário. A sensação de força fornece informações sobre o peso do objeto e sua consistência. Estes dispositivos constituem, principalmente, os manipuladores robóticos que empurram o usuário de encontro às forças que 
correspondem ao ambiente virtual (este tipo está presente em sistemas de treinamento para cirurgias, por exemplo).

Em projetos de luvas de dados, geralmente são utilizados sensores mecânicos ou de fibra óptica, com o intuito de captar os movimentos dos dedos. No caso da fibra óptica, um fio ou cabo óptico com junções é empregado no dispositivo para transferência de informações para o computador. Por isso, quando o usuário move seus dedos, consequentemente move as juntas, ocasionando a dobra do fio e a redução de passagem de luz, o que indica um movimento. Existem diversos tipos de luvas de dados no mercado, com variação de preço, número de sensores, desempenho, acurácia (NETTO; MACHADO; OLIVEIRA, 2002). Na Figura 7 é exibido um par de luvas 5DT Ultra Wireless Kit.

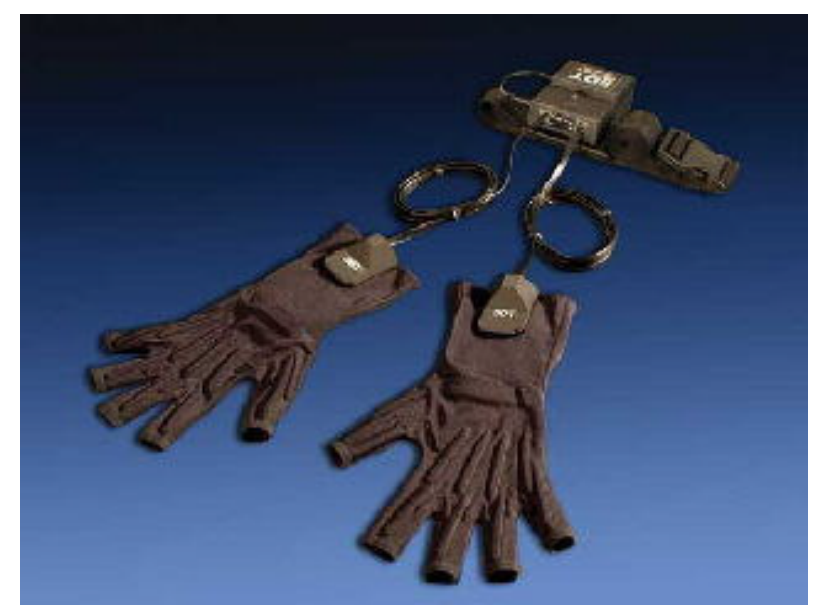

Figura 7 -5DT Ultra Wireless Kit

Fonte: (FIFTH..., 2015)

Na Figura 8 é exibido o dispositivo háptico Phantom Premium.

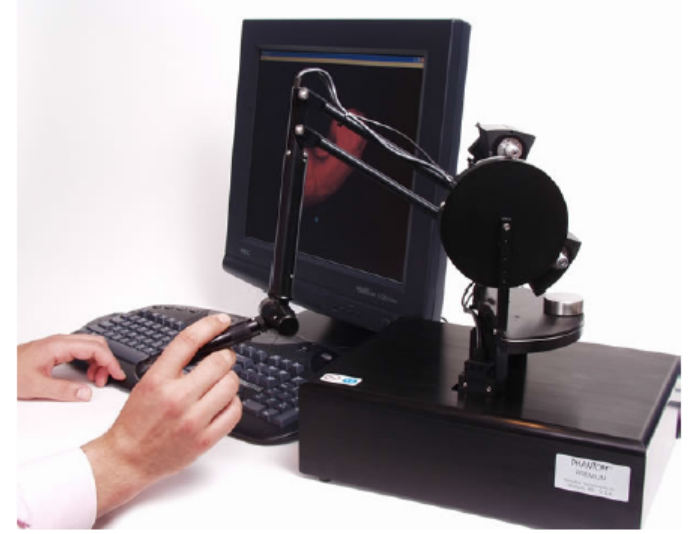

Figura 8 - PHANTOM Premium 1.5/6DOF

Fonte: (GEOMAGIC, 2015) 


\subsection{Visualização estereoscópica}

Em treinamento médico virtual, além da sensação háptica, a parte de visualização do AV é importante para a imersão do usuário. Uma das técnicas existentes a fim de melhorar este aspecto da RV é a estereoscopia, que cria a ilusão de profundidade e tridimensionalidade enquanto apresenta uma imagem diferente para cada olho (BAñOS et al., 2008).

As exibições estereoscópicas permitem uma visualização de profundidade, tornando a visão mais próxima da realidade. Portanto, a estereoscopia é o fenômeno no qual cada um dos olhos dos seres humanos vê imagens ligeiramente diferentes, as quais são reunidas pelo cérebro, que acrescenta características de profundidade, distância, tamanho e posição (MACHADO, 2003).

Um dos métodos mais conhecidos para implementar estereoscopia é o método de anaglifos. O termo anaglifo refere-se a objetos cujo produto final é obtido por uma combinação finita de cores (azul-vermelho ou verde-vermelho), gerando uma sensação de profundidade e imersão no ambiente (BOTEGA et al., 2005). Assim, cada um dos olhos utiliza um filtro diferente de cor, de acordo com a cor das lentes dos óculos (Figura 9). As lentes podem ser confeccionadas de papel celofane ou material semelhante, a fim de que o par estéreo possa ser visto.

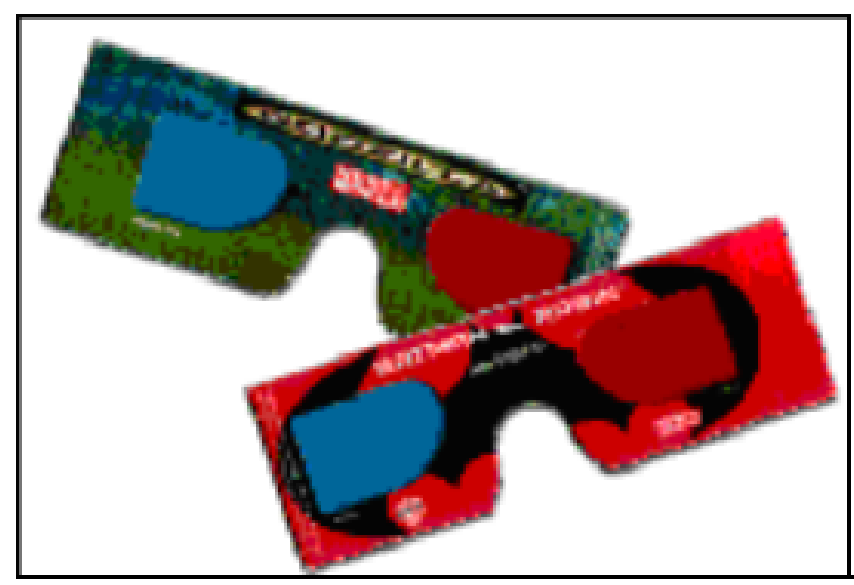

Figura 9 - Óculos esteroscópicos para visualização de anaglifos

Fonte: (SISCOUTTO et al., 2004)

Existem dispositivos específicos que propiciam a sensação de imersão usando o conceito de estereoscopia. Dentre os dispositivos estão os óculos estereoscópicos (Figura 
10), que geram imagens diferentes de uma mesma cena virtual para os olhos direito e esquerdo (RAPOSO et al., 2004).

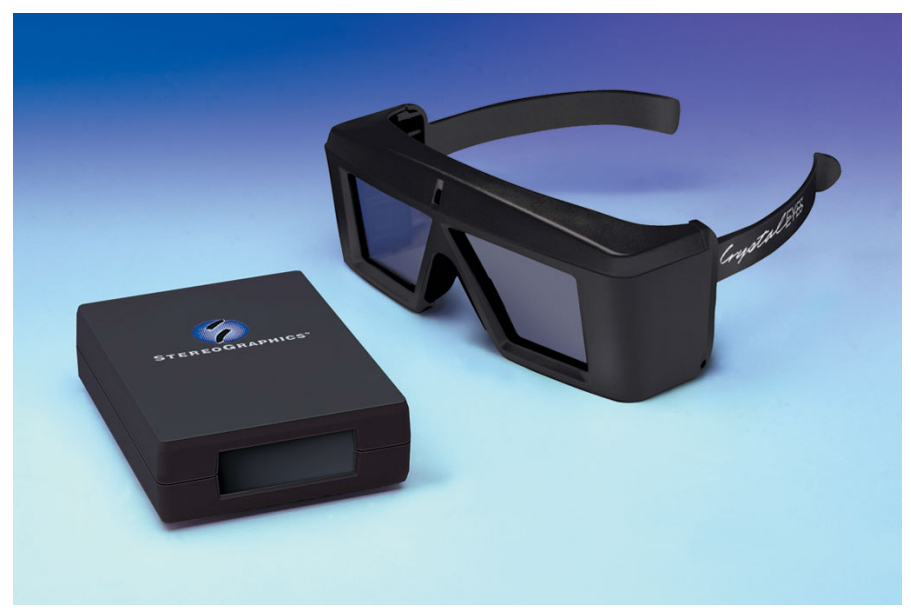

Figura 10 - Óculos estereoscópicos

Fonte: (ABSOLUTE..., 2015)

Os capacetes de sistemas de RV, também chamados de head mounted display (Figura 11) , permitem uma imersão visual, combinando rastreadores de movimentos da cabeça e sistemas de geração de imagens. Oferecem uma visão estereoscópica (um display para cada olho), incluindo, ainda, um campo de visão de 360 graus, de acordo com a orientação da cabeça, e sistemas de áudio (MOKHTARI et al., 2004).

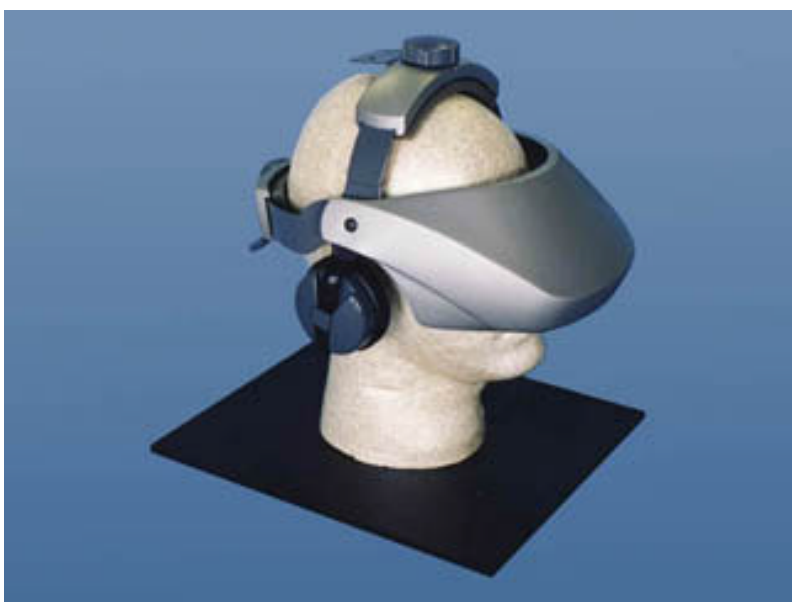

Figura 11 - 5DT Head Mounted Display

Fonte: (FIFTH..., 2015) 


\section{Simulação de exames de palpação com retorno háptico}

Este capítulo apresenta a condução e os resultados de uma Revisão Sistemática que teve como objetivo conhecer o estado da arte na área de simulação de exame de palpação com retorno háptico.

O capítulo está organizado da seguinte forma: na seção 3.1 são apresentados conceitos sobre RS, o protocolo utilizado e o processo de condução da revisão; na seção 3.2 é apresentada uma análise quantitativa dos trabalhos incluídos; na seção 3.3 é apresentada uma discussão sobre as áreas de aplicação contempladas pelos trabalhos; na seção 3.4 são discutidos os algoritmos empregados nos trabalhos; na seção 3.5 é apresentada uma discussão a respeito dos dispositivos hápticos utilizados nos trabalhos; na seção 3.6 é exposta uma discussão geral sobre os trabalhos incluídos na RS e, por fim, na seção 3.7 são apresentadas as considerações finais.

\subsection{Planejamento e Condução}

A RS é uma metodologia rigorosa de pesquisa bibliográfica que visa identificar estudos primários e secundários relacionados a um determinado tema de pesquisa. Ela permite avaliar e interpretar toda a pesquisa relevante desenvolvida sobre uma questão particular ou sobre um tópico de interesse (KITCHENHAM, 2004).

Segundo Kitchenham (2004) e Biolchini et al. (2007), uma RS é conduzida em três fases bem definidas: planejamento da revisão, execução da revisão e análise dos resultados. $\mathrm{Na}$ fase de planejamento se define um protocolo no qual são especificadas a questão de pesquisa e a metodologia que será empregada na execução da revisão. Integrarão esse protocolo os objetivos da RS, as fontes de consulta, os critérios de inclusão e de exclusão de estudos primários, as palavras-chave e outros tópicos de interesse para a pesquisa bibliográfica.

Na fase de Execução, a pesquisa bibliográfica propriamente dita é realizada. É nessa etapa que ocorrem a seleção dos estudos primários, de acordo com os critérios de inclusão e de exclusão definidos, e a extração e síntese de dados dos trabalhos incluídos. Por fim, na fase de Análise de Resultados, são realizadas a análise e a documentação dos resultados e das conclusões obtidas por meio deles. 
Uma importante diferença entre a RS e a revisão de literatura comum é o fato de que o estabelecimento de um protocolo permite que a revisão seja passível de reprodução e auditoria. Isso significa que outros pesquisadores podem reproduzir o mesmo protocolo, sendo também capazes de avaliar os métodos empregados para o caso em questão (BIOLCHINI et al., 2007). As subseções seguintes descrevem cada uma dessas fases da RS realizada.

\subsubsection{Planejamento}

A RS conduzida e aqui apresentada teve com objetivo principal conhecer o estado da arte com relação à área de simulação de exame de palpação com retorno háptico, com interesse nas principais técnicas e ferramentas utilizadas na área. Nesse contexto, foi definida a seguinte questão de pesquisa:

- Quais são as técnicas e ferramentas existentes para simular exame de palpação com retorno háptico?

Uma análise exploratória foi previamente conduzida, utilizando principalmente a ferramenta Google Acadêmico (GOOGLE..., 2015). Esta revisão inicial permitiu verificar que este tema é explorado desde os anos 90, porém tem recebido destaque no decorrer dos últimos nove anos. Sendo assim, optou-se por não limitar o tempo para recuperação de trabalhos sobre o tema de interesse.

A análise exploratória norteou a seleção das fontes de consulta e a definição das palavras-chave utilizadas na RS. Foram consultadas as bases que tradicionalmente publicam artigos sobre o tema, de acordo com a experiência de trabalhos anteriores do grupo de pesquisa e os dados colhidos na análise exploratória preliminar.

A seguir, são listadas as bases selecionadas:

- PubMed: base de citações e resumos de artigos científicos principalmente sobre tecnologia aplicada na área médica (PUBMED, 2015);

- IEEE Xplore Digital Library: base de artigos sobre engenharia e tecnologia publicados em periódicos e conferências científicas organizadas ou apoiadas pelo Instituto de Engenheiros Eletricistas e Eletrônicos (IEEE) (IEEE..., 2015);

- ACM Digital Library: base de artigos científicos e conferências científicas organizadas pela Association for Computing Machinery (ACM) (ACM..., 2015); 
- Biblioteca Digital de Teses e Dissertações da USP: base de teses e dissertações defendidas na USP (BIBLIOTECA..., 2015).

Para a realização das consultas nas bases selecionadas foi utilizada a seguinte composição de termos: ("force feedback" OR haptic* OR tactile) AND (palpation OR simulation OR ((surgical OR medical) AND training)).

O protocolo utilizado na presente Revisão Sistemática é apresentado em detalhes no Apêndice A.

Os termos deveriam estar presentes no título, no resumo, nas palavras-chave ou nos tópicos de indexação de um trabalho para que o mesmo fosse recuperado. Essas opções foram definidas por meio de ferramentas de busca avançada disponíveis nas bases de dados.

A fim de selecionar somente trabalhos relevantes para o tema de estudo foram definidos critérios de inclusão e exclusão. Foram incluídos somente trabalhos que atendessem a um dos critérios de inclusão e nenhum dos critérios de exclusão. Os critérios de inclusão definidos foram:

(a) trabalhos que apresentem técnicas ou ferramentas que simulem exame de palpação com retorno háptico;

(b) trabalhos que usem ou referenciem técnicas ou ferramentas que simulem exame de palpação com retorno háptico.

Já os critérios de exclusão adotados foram:

(c) trabalhos duplicados;

(d) trabalhos que não apresentem abstract/resumo;

(e) trabalhos que não simulam, apresentam ou referenciam procedimentos de palpação.

\subsubsection{Condução}

Na Figura 12 é apresentado um diagrama de fluxo, baseado em (LIBERATI et al., 2009), que sumariza a seleção de estudos realizada.

Todos os estudos encontrados relacionados à área de pesquisa em questão foram considerados, independentemente do ano de publicação. A revisão sistemática foi conduzida de Março de 2014 até Setembro de 2014. A busca por materiais que tratavam de simulação de exame de palpação com retorno háptico retornou 1433 trabalhos, e após a aplicação dos 


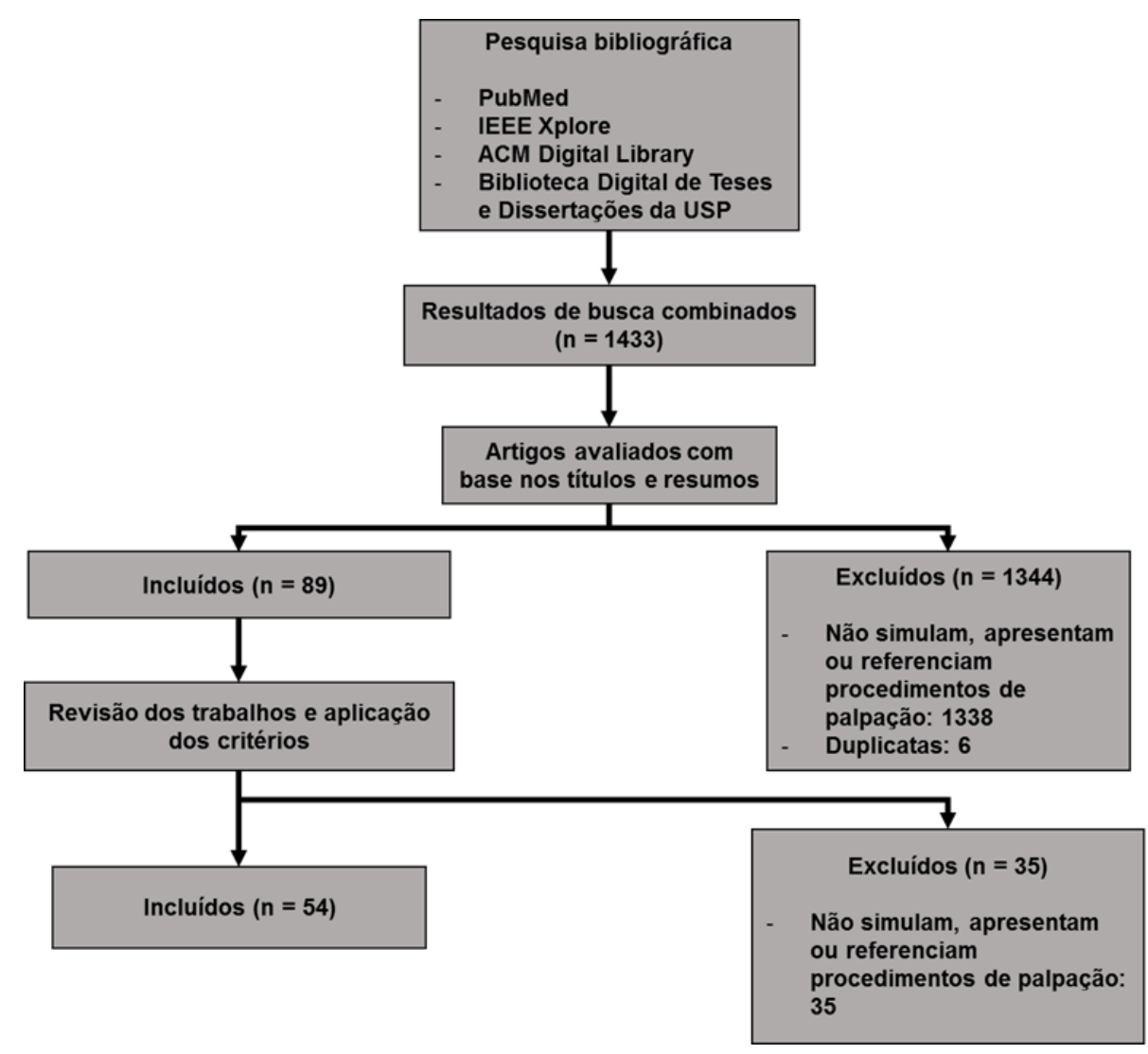

Figura 12 - Diagrama de fluxo sumarizando a etapa de seleção de estudos.

critérios de inclusão e exclusão, 54 artigos foram selecionados e analisados por completo, sendo 35 da base PubMed, 15 da base IEEE Xplore e quatro da ACM Digital Library. Toda a etapa de condução da RS foi devidamente documentada tomando-se como base os modelos e formulários propostos em (BIOLCHINI et al., 2007) e (KITCHENHAM, 2004).

\subsection{Análise quantitativa dos trabalhos incluídos}

Os resultados da revisão conduzida mostram que as pesquisas para a simulação de palpação com retorno háptico são recentes, concentrando-se nos últimos nove anos. A Figura 13 mostra a evolução da quantidade de trabalhos no tempo e revela que as pesquisas na área de palpação com retorno háptico têm se intensificado nos últimos anos. Assim, há indícios de que existem muitos desafios a serem resolvidos nesta área que, apesar de nova, tem muitos trabalhos promissores e apresenta uma tendência de crescimento.

No Apêndice B é apresentada uma síntese dos 54 artigos analisados. Os artigos foram divididos em categorias considerando tanto a área de aplicação do trabalho quanto o algoritmo utilizado na implementação da ferramenta. 


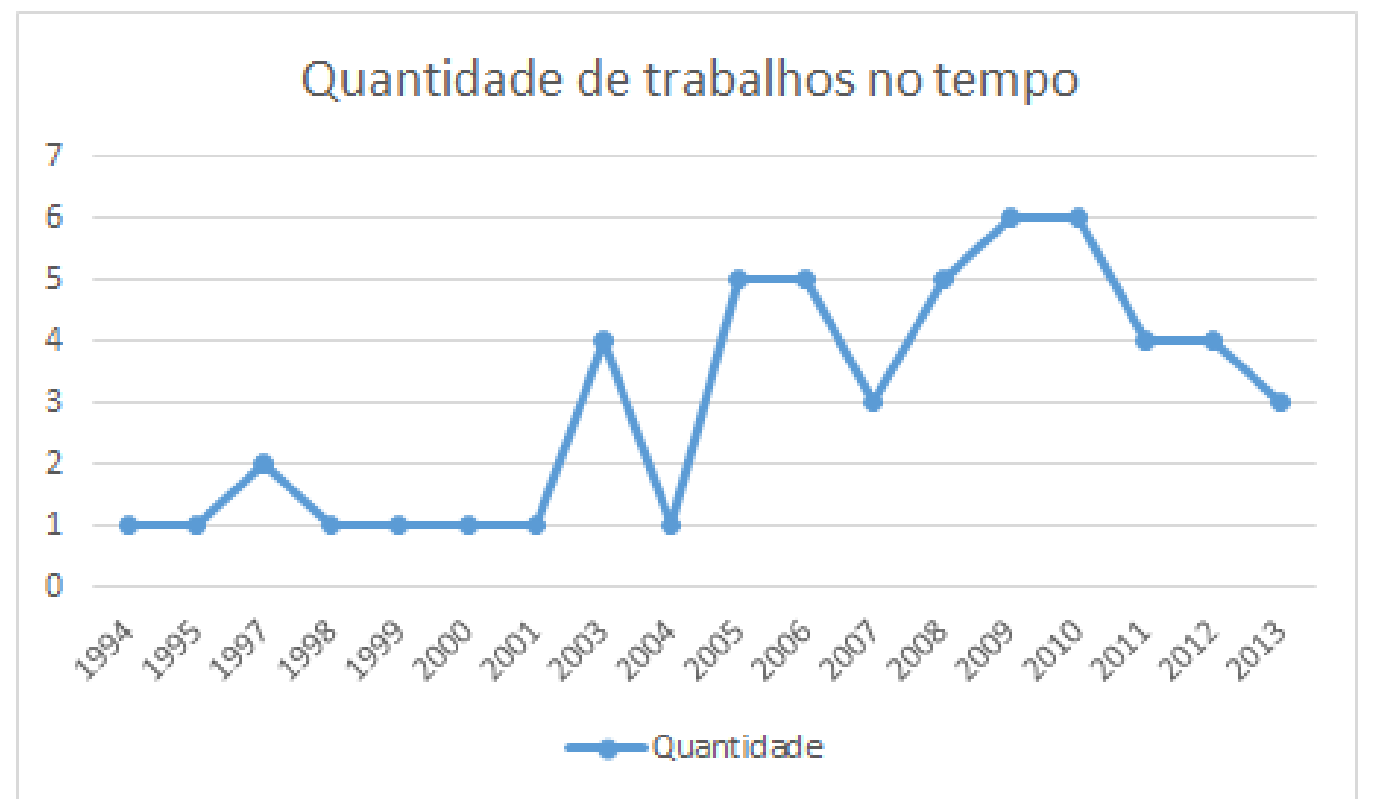

Figura 13 - Gráfico de quantidade de trabalhos no tempo.

A Figura 14 exibe o gráfico com a porcentagem de trabalhos de cada tipo de dispositivo háptico. Verifica-se que os dispositivos Phantom foram adotados em $60 \%$ dos 52 trabalhos que utilizam dispositivos hápticos, provavelmente devido à boa relação custo versus benefício por ele proporcionada, discutida posteriormente na subseção 3.5.1 deste trabalho.

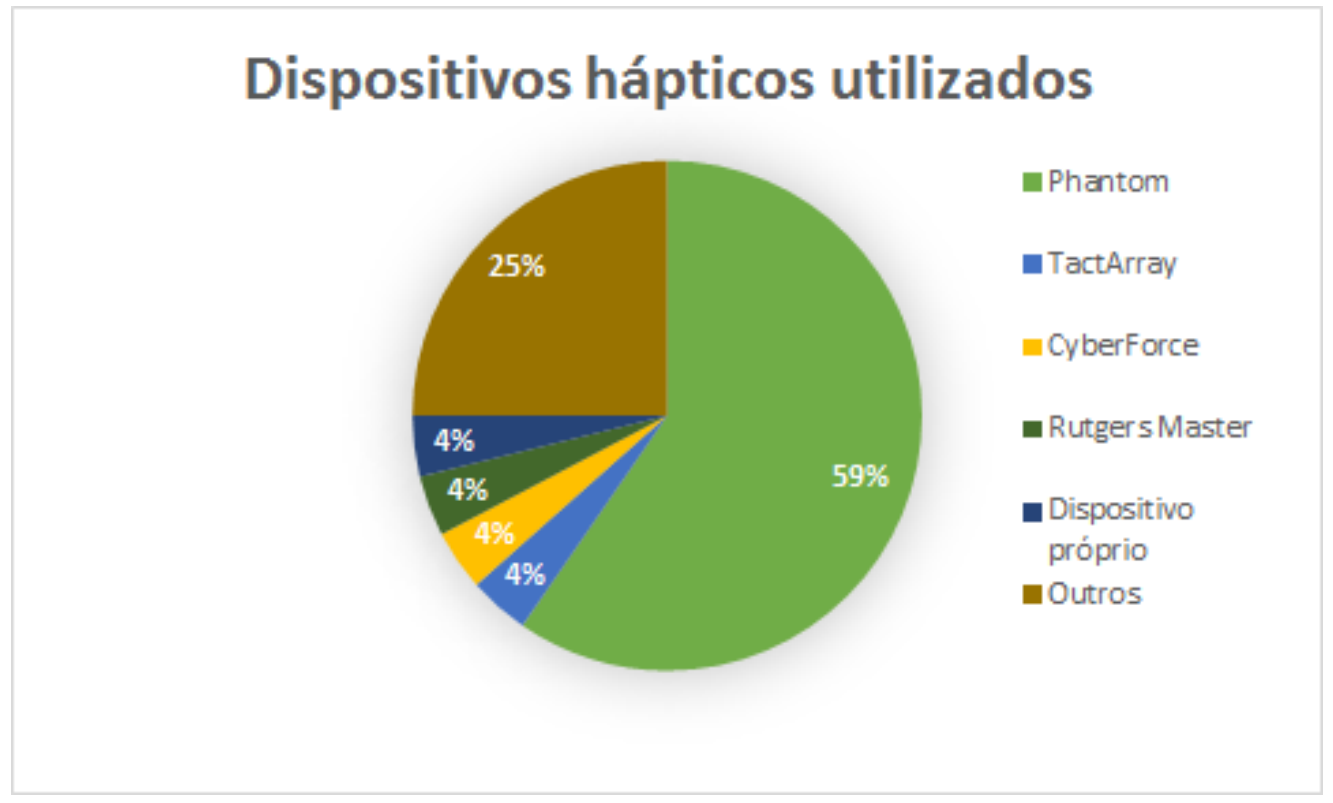

Figura 14 - Gráfico de dispositivos hápticos utilizados nos trabalhos.

A divisão dos trabalhos em área de aplicação é apresentada na Figura 15, evidenciando o interesse no desenvolvimento de trabalhos de simulação de palpação para 
procedimentos cirúrgicos. Este interesse é discutido posteriormente neste trabalho, assim como os demais aspectos relacionados aos problemas existentes nas diferentes áreas, e como a simulação de palpação pode ajudar na solução destes problemas.

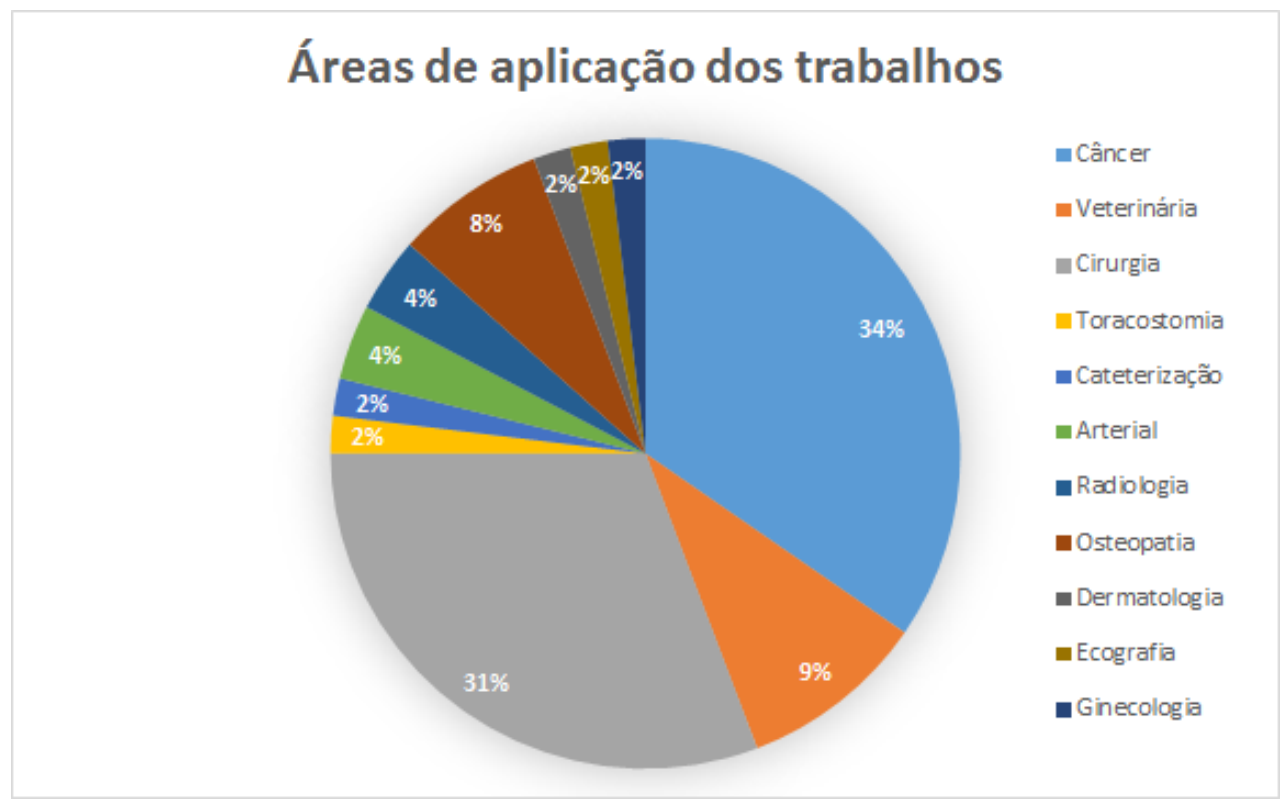

Figura 15 - Gráfico de áreas de aplicação dos trabalhos.

Vários procedimentos da área de saúde utilizam dois ou mais dedos no exame real. Todavia, a simulação de diversos pontos de contato durante detecção de colisão não é uma tarefa trivial. Visando a contribuir com esta discussão, neste trabalho este aspecto foi analisado, podendo-se classificar os trabalhos conforme apresentado na Figura 16. É perceptível que grande parte dos simuladores ainda utiliza dispositivos com poucos pontos de contato. Isto pode ser atribuído ao fato de que dispositivos como luva de dados apresentam um custo muito elevado, o que compromete a realidade da simulação de palpação. Outros fatores e consequências desta escolha serão discutidos posteriormente neste trabalho (seção 3.5).

\section{3 Áreas de aplicação contempladas}

A revisão conduzida mostra que nos últimos anos, em especial na última década, foram publicadas várias pesquisas em diferentes áreas, no sentido de oferecer retorno háptico aos simuladores de palpação, conforme detalhado a seguir. 


\section{Quantidade de pontos de contato}

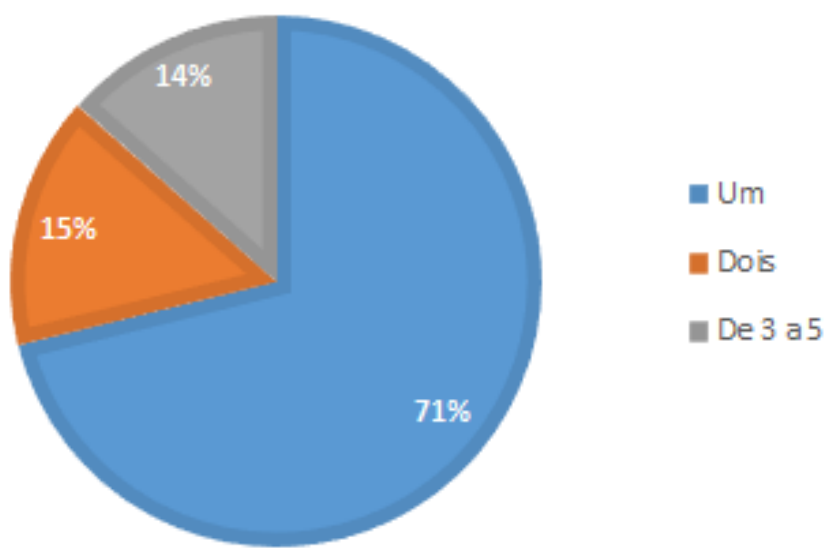

Figura 16 - Gráfico de quantidade de pontos de contato utilizados.

\subsubsection{Palpação cirúrgica}

A área de procedimentos cirúrgicos foi contemplada em 16 trabalhos incluídos (30\%). Esta área apresenta uma tendência crescente de desenvolvimento de recursos para auxílio em cirurgias minimamente invasivas. Este tipo de cirurgia está sendo cada vez mais adotado no campo médico devido às suas vantagens em relação às cirurgias tradicionais, principalmente no concernente a custo e tempo de recuperação do paciente. Contudo, a maior dificuldade deste tipo de cirurgia reside no fato de que a percepção dos profissionais pode ficar comprometida devido ao menor campo de visão do qual eles dispõem, coordenação inapropriada entre os olhos e as mãos e, acima de tudo, a limitação de retorno de força dos instrumentos médicos.

Um dos trabalhos pioneiros na área foi de Langrana et al. (1994) que desenvolveram o modelo virtual de um joelho, cujo objetivo era auxiliar o planejamento de cirurgias e no qual foi utilizado o dispositivo háptico Rutgers Master, o qual é acoplado a uma luva de dados e permite o uso de quatro dedos.

Talasaz e Patel (2012) seguem a linha de desenvolvimento de ferramentas que auxiliam os profissionais em situações nas quais o retorno de força é ainda mais crítico. Os autores apresentam um método integrado de força tátil para localizar nódulo de forma minimamente invasiva utilizando robôs. De acordo com os pesquisadores, os resultados do experimento conduzido com este método confirmaram que ele pode contribuir significati- 
vamente para o treinamento de detecção de nódulos por meio da palpação, pois possibilita ao aprendiz verificar a força aplicada. No contexto da cirurgia minimamente invasiva isto é importante, visto que neste tipo de procedimento, os profissionais lidam com tecidos mais delicados e a capacidade de saber a força necessária a ser aplicada pode evitar danos aos órgãos sendo examinados.

Suzuki et al. (1998) desenvolveram um dos primeiros sistemas de cirurgia virtual, utilizando um dispositivo háptico com 16 graus de liberdade e um head-mounted display para visualização do ambiente virtual, proporcionando um nível de imersão pouco conhecido na época. Um trabalho mais recente a ser evidenciado neste contexto é o de Tokuyasu et al. (2010), que desenvolveu um sistema de simulação cirúrgica com a função de treinamento que lida com o aspecto de herança, ou seja, permite que os praticantes sintam as sensações de cirurgiões experientes enquanto operam. Desta maneira, retorna ao usuário a sensação correta de retorno de força, a qual é disponibilizada pela contribuição do profissional experiente.

Na mesma linha, Nakagawa e Oguro (2009) desenvolveram um sistema para treinamento de palpação cardíaca.De acordo com os pesquisadores, estas cirurgias oferecem um risco muito alto e demandam uma experiência considerável para a realização do diagnóstico destes problemas. Portanto, é encorajada a oferta de ferramentas que possam melhorar as habilidades de palpação dos profissionais e façam com que estudantes vivenciem de forma prática as situações que eles só teriam acesso mais tarde em suas carreiras.

\subsubsection{Palpação para detecção de câncer}

O exame de palpação é um dos principais meios de identificação de vários tipos de câncer e dispõe de uma incontestável taxa de sucesso na detecção e prevenção deles (VEITCH et al., 2011). Mesmo assim, muitos profissionais de Medicina não têm plena confiança em suas habilidades para a condução deste exame, na sua grande maioria, em decorrência da ausência de treinamento, o qual eles gostariam de ter, caso lhes fosse oferecida a oportunidade (VEITCH et al., 2011).

O grande problema de simulação desses procedimentos é a ausência de modelos adequados para simular os diversos casos percebidos na prática clínica real. Exemplos que corroboram esta afirmação são os modelos de silicone, que se desgastam com o uso, além 
de estarem limitados a simular órgãos com composição similar a este material (COLES; MEGLAN; JOHN, 2011).

Este cenário não reflete a realidade, uma vez que cada paciente tem determinadas particularidades, o que torna a sua simulação mais difícil. O recrutamento de indivíduos para o treinamento deste tipo de exame também é uma tarefa complicada, que pode comprometer ainda mais a capacidade de treinamento dos aspirantes.

Na RS foram encontrados 14 trabalhos que desenvolveram ferramentas nesta área. Todos eles mostraram uma preocupação com a calibração dos parâmetros para detecção de nódulos, assim como o desenvolvimento de modelos de tecidos virtuais que simulem um nódulo de forma realista, como exposto em Khaled et al. (2003), Kim et al. (2009) e Hosseini et al. (2010). Khaled et al. (2003) empregaram o método para construir a forma, tamanho, profundidade e localização de nódulos simulados. Hosseini et al. (2010), Hosseini et al. (2006) preocuparam-se em determinar as propriedades mecânicas dos tecidos biológicos dos nódulos. Kim et al. (2009), por sua vez, utilizam o método para fazer a predição de forças de retorno para várias profundidades de nódulos. É interessante observar o uso da mesma técnica para definir a deformação de um modelo de tecido virtual, assim como para realizar o cálculo de retorno de força para um dispositivo háptico manipulado por um profissional ou estudante de Medicina. Ou seja, a mesma técnica foi aplicada para tarefas distintas, porém relacionadas, expondo assim, a sua versatilidade e eficiência.

Foram encontrados trabalhos com foco em detecção de câncer em diferentes partes do corpo, porém é válido ressaltar que quatro trabalhos estão relacionados à detecção de câncer de mama. Os trabalhos de Jeon et al. (2010), Jeon, Choi e Harders (2012) têm foco neste procedimento utilizando realidade aumentada. Em Jeon, Choi e Harders (2012), o foco foi a reprodução fiel da força normal retornada ao longo da palpação. Nos trabalhos de Alhalabi et al. (2005) e Mclaughlin et al. (2003), o foco foi simular com fidelidade o retorno de força nos três dedos que realizam o procedimento (indicador, médio e anelar). Alhalabi et al. (2005), por sua vez, mostraram que o tempo de diagnóstico de um nódulo por usuários especialistas e leigos, assim como o erro de identificação da posição do nódulo, foram muito próximos na simulação que conduziram.

McCreery et al. (2007) desenvolveram um trabalho para elucidar uma medida ideal para que um sensor detecte e localize pequenos nódulos no pulmão. Os resultados indicaram que a comparação entre forças de palpação revelam uma maior força de retorno na presença de um nódulo. 
Adicionalmente, os trabalhos de Dinsmore et al. (1997) e Langrana et al. (1997) compartilharam esforços para a implementação de um simulador de palpação do fígado, no qual o método de elementos finitos foi utilizado para determinar o quanto de força deveria ser retornado ao usuário. De acordo com os pesquisadores, os experimentos conduzidos indicaram que os usuários foram capazes de identificar nódulos com pouco treinamento, mas a diferenciação da rigidez do nódulo demanda mais tempo de treinamento.

\subsubsection{Radiologia intervencional}

A palpação na radiologia intervencional tem um papel importante no propósito de tratar patologias como sangramento, nódulos, bloqueio de artérias e aneurismas, constituindo uma alternativa efetiva para a cirurgia tradicional (LUBOZ et al., 2013). Contudo, conseguir acesso às veias e realizar a navegação de instrumentos dentro delas requer habilidades cujo treinamento constitui uma tarefa difícil. De acordo com Luboz et al. (2013), a técnica Seldinger é o principal recurso utilizado para acessar uma veia ou artéria, e consiste em guiar uma agulha considerando o auxílio da sensação de toque do operador ou imagens de ultrassonografia. Com o objetivo de auxiliar no treinamento deste procedimento, Luboz et al. (2013) desenvolveram um simulador para a técnica citada, utilizando duas estações de trabalho: uma para palpação vascular, anestesia local e punção com agulha e outra para cateterização. O simulador dispõe de vários dispositivos hápticos com retorno de força, mais notadamente o Phantom Omni na primeira estação de trabalho para punção com agulha e outros dois na segunda estação de trabalho (um para manipulação da agulha, desenvolvido pelos autores para o trabalho e outro para cateterização, o dispositivo comercial Vascular Simulation Platform).

Dentro desta área, outro trabalho notável foi o de Coles, Meglan e John (2011), que consistiu na implementação do simulador PalpSim, cujo objetivo é treinar o procedimento de palpação femoral e inserção de agulha. A palpação femoral conta com um dispositivo Falcon adaptado que oferece cinco graus de liberdade, o qual é conectado a uma bandeja de silicone que permite a palpação com os dedos das mãos. É utilizado um dispositivo Phantom Omni adaptado para simular a inserção da ponta de uma agulha, oferecendo três graus de liberdade. Para aumentar o realismo, o sistema também oferece, por meio de recursos de RV, a representação do ambiente virtual do procedimento. 


\subsubsection{Medicina osteopática e fisioterapia}

A simulação de procedimentos relacionados ao campo de ortopedia foi contemplada por dois trabalhos na presente revisão. Williams II et al. (2004) conceberam um modelo gráfico e háptico realista do dorso humano, que poderia ser utilizado para treinamento médico em palpação, como um passo rumo a uma modelagem mais compreensiva do corpo humano.

Howell et al. (2008a), Howell et al. (2008b) apresentaram a avaliação da ferramenta citada junto a estudantes da área, a fim de determinar o seu potencial de aprendizado. Em ambos os estudos, verificou-se que após a sessão prática com o simulador, os estudantes melhoraram sua acurácia e velocidade em relação a um teste inicial que avaliou as habilidades dos mesmos. No simulador citado foram empregados dois dispositivos hápticos Phantom 3.0 e foi implementada a palpação utilizando as duas mãos, buscando simular a técnica utilizada por estes profissionais. Além disso, foi disponibilizada a visualização do dorso humano com a vértebra e escápula. O método massa-mola foi empregado para calcular o retorno visual de colisão e deformação dos objetos virtuais.

\subsubsection{Cateterização}

Os cateteres são tubos que permitem aos profissionais da Medicina acessar o interior do corpo humano facilmente e de forma indolor, por meio de orifícios naturais e das veias. Ainda que eles permitam o transporte de fluidos e drogas, assim como o desenvolvimento de dispositivos e aquisição de medidas, eles não permitem que os clínicos confirmem as propriedades físicas do tecido interno, em decorrência do movimento do tecido e limitações de transmissão dos tubos (LUBOZ et al., 2013).

A fim de preencher esta lacuna, o trabalho de Kesner e Howe (2011), que realizaram o desenvolvimento de um sistema de cateter que busca aumentar a informação tátil disponível para os médicos durante procedimentos de inserção de cateter, por meio da oferta de retorno háptico durante procedimentos de palpação. Os pesquisadores apresentam um sistema de cateter que permite a percepção háptica de estruturas intracardíacas de movimento rápido, e mostra a importância de retorno háptico e compensação de movimento para percepção das propriedades de movimentação dos tecidos. O dispositivo háptico 
utilizado, o qual oferece um grau de liberdade, permite que o usuário forneça a posição do cateter, enquanto oferece retorno de força para o usuário.

\subsubsection{Palpação arterial}

O pulso é um dos principais meios de diagnóstico na área médica, por ser capaz de fornecer informação sobre a pressão sanguínea e monitorar o sistema circulatório, além de determinar a posição das artérias (ULLRICH et al., 2008). O primeiro trabalho a simular este efeito para o procedimento de palpação foi o de Ullrich et al. (2008), no qual múltiplas partículas emissoras de pulsos são utilizadas para modelar uma região que emite pulsos. Assim, quando um usuário utilizando um dispositivo háptico, aproxima-o de uma ou mais partículas, o retorno háptico varia, simulando o pulso arterial da região de interesse.

Continuando o trabalho anterior, Ullrich e Kuhlen (2012) conceberam um framework de simulação de palpação, por meio do desenvolvimento de um algoritmo de interação com arrasto de tecido. Este algoritmo divide-se em duas partes: a primeira lida com as forças aplicadas pelos objetos do ambiente, com a finalidade permitir múltiplas camadas de anatomia e a segunda proporciona retorno de força do pulso, que tem o objetivo de simular o pulso arterial.

É utilizado o método de elementos finitos para simulação da deformação de tecidos moles. O simulador oferece interação com ambas as mãos por meio da combinação das técnicas supracitadas, para que uma das mãos possa proceder com a palpação e a outra possa realizar a inserção da agulha. A validação do simulador evidenciou que o mesmo foi considerado relevante, assim como o algoritmo de interação para palpação proposto também teve sua plausibilidade médica comprovada.

\subsubsection{Medicina veterinária}

Na Medicina veterinária, a palpação retal bovina é realizada para diagnóstico de gravidez, fertilidade e como parte do exame clínico de praxe. O procedimento é difícil de aprender, por isso demanda bastante prática, a qual também é de difícil acesso, visto que as oportunidades de treinamento são limitadas (BAILLIE et al., 2005). Com o objetivo de oferecer um complemento aos métodos de treinamento existentes, foram desenvolvidos alguns simuladores de palpação retal bovina. 
Baillie et al. (2005) apresentaram os trabalhos mais antigos desta área recuperados na presente revisão, nos quais propuseram um simulador capaz de fornecer visualização do desempenho dos aprendizes e orientá-los no sentido de melhorar tal desempenho, algo que não é possível quando a palpação é realizada diretamente no animal.

No trabalho de Baillie et al. (2010) é descrita a evolução do trabalho anterior, que disponibiliza ao aprendiz um auxílio ao treinamento, por meio da correção dos seus movimentos e estímulos sonoros, eliminando a necessidade de um instrutor ao seu lado durante a realização do treinamento. Isto é melhor para os estudantes, que têm a liberdade de usar o simulador quando desejarem, e para a instituição de ensino, pois uma versão que remove a dependência de um profissional é mais sustentável. Ainda assim, o melhor cenário no sentido de maximizar o impacto do simulador nas habilidades do usuário, é uma mistura do treinamento automatizado e com o auxílio do instrutor (BAILLIE et al., 2010).

Parkes, Forrest e Baillie (2009) apresentaram um simulador de palpação abdominal felina, cujas oportunidades são limitadas em decorrência da pouca tolerância dos animais a exames. Além disto, a ferramenta permite que um instrutor possa acompanhar o desempenho do estudante e o auxilie ao longo da realização do exame, ou seja, os detalhes da palpação do usuário podem ser vistos pelo profissional por meio de dispositivo de visualização.

\subsubsection{Outros procedimentos}

Na área ginecológica, a palpação da vagina e do colo do útero é importante para detecção da presença de nódulos cancerígenos, por meio da busca destes indícios e da verificação da elasticidade do tecido (MACHADO; MORAES, 2006). A partir dessas premissas, os pesquisadores apresentaram um sistema para simular tal procedimento, usando o dispositivo háptico Phantom Omni para retorno de força.

A toracostomia com tubo é a inserção de um tubo no espaço pleural para drenagem de líquido, sangue ou ar, com o objetivo de aliviar a pressão nos pulmões conforme definem Everett et al. (2009). Os pesquisadores criaram um aparato físico que oferece retorno de força direcionado à ponta do dedo do usuário durante a palpação de uma superfície externa, assim como a sensação de compressão ao redor do dedo durante a inserção do mesmo no corpo. Cada componente de constrição é constituído de dois invólucros de nylon revestido 
com um silicone de elastômero, colocado sobre as partes superior e inferior do dedo. Além disso, o dispositivo comunica-se com um ambiente virtual que auxilia na interação do usuário e sua percepção do paciente virtual.

Na área de dermatologia, o diagnóstico de algumas doenças de pele dá-se por meio da realização da palpação e atribuição de um score, determinado com base na experiência do profissional (LEE et al., 2013). Com o objetivo de oferecer retorno tátil para a pele foi desenvolvido por Lee et al. (2013) um protótipo de um sistema para simular rugas de pele utilizando o Phantom Omni.

De acordo com os pesquisadores por utilizar o dispositivo Phantom Omni, o sistema oferece apenas um ponto de contato. Por isso, pode-se argumentar que isto poderia prejudicar a capacidade do profissional de discriminar a rugosidade da pele e diminuir a percepção pela impedância criada pela ligação mecânica entre a pele e a mão, em comparação com o dedo descoberto. Contudo, os autores afirmam que a percepção de formas tridimensionais com a mão requer uma interpretação mais cinestésica, ou seja, a percepção das juntas dos dedos, em vez de informação cutânea (interpretação tátil dos dedos). Para a percepção de texturas tridimensionais, a situação é oposta. Portanto, um dispositivo com apenas um ponto de contato é suficiente para que o usuário possa estudar a rugosidade da pele (LEE et al., 2013).

\subsection{Algoritmos empregados}

Além de fornecer retorno háptico, 22 dos trabalhos incluídos (41\%) dispõem de recursos de visualização que permitem ao usuário conferir os resultados correspondentes ao retorno háptico fornecido. Nesses trabalhos são utilizados diversos algoritmos para funcionalidades como deteç̧ão de colisão dos objetos virtuais, assim como a deformação que ocorre neles após a colisão.

Um dos principais desafios de simuladores para a área de palpação é desenvolver modelos de tecidos moles que aumentem o nível de realismo da simulação, reproduzindo ou adaptando características de tecidos reais. Métodos clássicos como elementos finitos e massa-mola têm sido explorados nesta categoria de trabalhos, como os apresentados em

Frisoli, Borelli e Bergamasco (2005), Choi, Sun e Heng (2003) e Basafa, Sefati e Okamura (2011) 
A seguir são detalhados os algoritmos dedicados à representação da deformação de tecidos virtuais, encontrados ao longo da revisão, seus respectivos propósitos no contexto do trabalho em que foram aplicados, bem como considerações gerais a respeito da sua escolha. Vale ressaltar que alguns dos trabalhos consistiram no desenvolvimento de ferramentas, sem qualquer funcionalidade referente à representação virtual e, portanto, estes não serão considerados nesta seção.

\subsubsection{Método de Elementos Finitos}

O Método de Elementos Finitos (MEF) foi a técnica mais utilizada nos trabalhos, aparecendo em 12 dos 22 que citam algoritmos. Vuskovic et al. (2000) afirmam que este método é um meio clássico e preciso de resolver problemas mecânicos contínuos de valores-limite, definidos por superfícies de contato e forças. Porém, os autores também atribuem sua maior desvantagem ao seu alto custo computacional, o que limita o seu uso a sistemas que demandem menos processamento, minimizando, assim, o custo computacional. Por outro lado, afirmam que com uma formulação apropriada e implementação usando algoritmos paralelos e escaláveis, em hardware também paralelo, o método pode ser aplicado a sistemas mais complexos. Este foi o caso do trabalho de Alhalabi et al. (2005), no qual o método foi considerado rápido o suficiente para a renderização de um modelo relativamente complexo da mama, em tempo real.

Frisoli, Borelli e Bergamasco (2005) fazem uma adaptação da abordagem multiresolução do MEF, propondo uma abordagem híbrida para o cálculo da deformação. Os autores dividem o modelo em duas malhas, de forma que a deformação na área de contato seja mais realista. Zhong et al. (2009), no entanto, afirma que este método é computacionalmente caro e apenas suas variações mais simples têm sido utilizadas em deformação. Assim, seu trabalho apresenta o desenvolvimento de um método de deformação baseado na análise teórica de comportamentos de tecidos moles do ponto de vista eletromecânico, em vez de se basear numa analogia feita a partir das observações do fenômeno físico. Choi, Sun e Heng (2003) também mencionam que a complexidade do MEF é um problema para as aplicações de RV que apresentam taxas altas de renderização.

O trabalho de Luboz et al. (2013) utiliza o MEF para a formulação da deformação de tecidos em consequência do procedimento de punção com agulha. A fim de reduzir o tempo de computação, a agulha é simulada com um modelo rígido, e seu retorno de força 
é modelado como a soma das forças de resistência do tecido, a força produzida quando a agulha penetra ao longo das camadas de tecido e a força causada pela pressão do pulso.

No que diz respeito a trabalhos que lidam simulação de palpação, Hosseini et al. (2006) propõem um método para modelagem de tecido que contém um nódulo simulado, e o MEF é utilizado para prover as propriedades do nódulo, como formato, tamanho, profundidade e localização. No trabalho de Hosseini et al. (2010), a partir da sensação tátil e palpação de um profissional da medicina em busca de nódulos anormais, foi proposta a simplificação e modelagem de um tecido contendo um nódulo, para, por fim utilizar elementos de contato a fim de analisar a função do sensor tátil. O MEF foi usado neste contexto para fazer com que os efeitos da massa aparecessem na superfície do tecido gerado. Em (ULLRICH; KUHLEN, 2012), é utilizada uma abordagem co-rotacional do MEF para simulação de tecidos moles, com a funcionalidade de arrasto de tecido de um paciente virtual. Isto tem como objetivo a simulação da palpação do pulso de uma pessoa.

\subsubsection{Método Massa-mola}

O método massa-mola é amplamente utilizado para modelagem de objetos deformáveis, visto que pode ser implementado facilmente e em tempo real, além de possibilitar o cálculo de geometrias complexas (BASAFA; SEFATI; OKAMURA, 2011). O principal propósito da utilização deste algoritmo nos trabalhos incluídos foi para simular a deformação de tecidos moles quando ocorre alguma colisão com objetos do ambientes virtual. Quando aliado ao retorno de força, este método oferece simulação da interação completa ao usuário.

Dos 22 trabalhos que citaram algoritmos utilizados, cinco adotaram o algoritmo massa-mola para a modelagem nos trabalhos. Basafa, Sefati e Okamura (2011) conduziram uma calibração dos parâmetros para adaptar as características do modelo desenvolvido às de tecidos reais. Para simulação realista do comportamento de força de deslocamento nãolinear de tecidos moles, as molas lineares foram substituídas por não lineares, assim como foi acrescentada uma força de amortecimento a cada nó no modelo. Nele, o método massamola não linear é utilizado para simular tecidos moles deformáveis e oferecer retorno de força ao usuário. Esta escolha é justificada pelo fato de que eles podem ser implementados facilmente e resolvidos em tempo real. É interessante notar que os trabalhos procuram desenvolver as soluções pertinentes às suas necessidades, enquanto justificam as escolhas 
por determinadas técnicas para fazê-las. Isto permite que as novas pesquisas sigam o caminho de aperfeiçoamento das tecnologias existentes e a criação de técnicas inovadoras.

Em (CHOI; SUN; HENG, 2003) a força aplicada em um nó é propagada para os seus nós vizinhos por meio das molas interconectadas. Para implementar o mecanismo de propagação, uma lista de nós é criada, com base na busca em profundidade que arranja as camadas de nós na vizinhança, até o ponto de contato na ordem de profundidade crescente. Segundo os autores, este modelo é uma alternativa computacionalmente eficiente e de fácil implementação, já que as formulações de matrizes e operações sobre elas não são necessárias.

Tokuyasu et al. (2010) combinaram dois modelos diferentes: um dedicado ao cálculo da força de reação a um estímulo recebido por um dispositivo háptico e o outro para expressar a deformação do objeto virtual. Já no trabalho de Luboz et al. (2013) o MEF é agregado ao massa-mola para simulação da cateterização, representando os objetos virtuais cateter e fio. O modelo consiste de um conjunto de partículas de mesma massa, conectados por molas rígidas de comprimento semelhante. As primeiras partículas correspondem à ponta do instrumento, enquanto as subsequentes representam seu corpo. De acordo com os pesquisadores, este tipo de representação permite que sejam modelados instrumentos de diferentes formas e que a resposta da colisão seja facilitada.

\subsection{Dispositivos hápticos}

Dos 54 trabalhos incluídos, apenas dois não mencionam o uso de dispositivos hápticos, visto que visam a estabelecer algoritmos de renderização háptica direcionados a aplicações específicas. Os restantes usam dispositivos diversos, destacando-se os equipamentos comercialmente disponíveis, conforme detalhado a seguir.

\subsubsection{Dispositivo Phantom}

O dispositivo Phantom, em suas diversas versões, criado e mantido pela empresa Geomagic (GEOMAGIC, 2015), aparece em 31 trabalhos, e é um dos principais dispositivos comerciais disponíveis atualmente no mercado. As diferenças entre as versões estão nos recursos de interação, graus de liberdades, seu valor máximo de retorno de força, entre outras características. 
A versão mais utilizada nos trabalhos é o Phantom Omni (atualmente chamado de Geomagic Touch) (GEOMAGIC, 2015), com seis ocorrências. Por ter uma ferramenta semelhante a uma caneta stylus como principal instrumento de interação, este dispositivo é adotado como principal meio de simulação de procedimentos com agulha, visto que a estrutura é muito semelhante, como exemplificado em (MACHADO; MORAES, 2006). Grande parte da adesão dos pesquisadores a esta ferramenta também se deve à sua capacidade de adaptação simples e eficiente.

Em (COLES; MEGLAN; JOHN, 2011), a estrutura da caneta foi substituída pela ponta de uma seringa, a fim de acrescentar maior realismo à interação. Em (ULLRICH; KUHLEN, 2012) foi acoplado à estrutura de interação um pequeno bloco de borracha esponjosa, para realizar a palpação com os dedos, juntamente com a manipulação da agulha por meio da interação tradicional oferecida pelo dispositivo.

O projeto Virtual Haptic Back (VHB), apresentado em (WILLIAMS II et al., 2004), utiliza como principal meio de interação háptica o dispositivo Phantom Premium 3.0, que também tem uma estrutura semelhante a uma caneta para interação háptica. Para este projeto também foi feita uma adaptação no dispositivo, por meio da substituição da caneta stylus utilizada na interação, por um pequeno compartimento que acomoda a ponta do dedo do usuário, a fim de permitir que os usuários pudessem interagir com o ambiente por meio das pontas dos dedos. O VHB utiliza dois dispositivos, de forma a condicionar o uso de ambas as mãos, o que reflete o ambiente real encontrado pelo profissional da área de Medicina osteopática. Uma das principais vantagens deste dispositivo diz respeito ao seu retorno máximo de força, de $22 \mathrm{~N}$, melhorando o realismo oferecido ao usuário. Outra variação do dispositivo, o Phantom Premium 1.5, é utilizado nos trabalhos de Basafa, Sefati e Okamura (2011) e Tokuyasu et al. (2010), nos quais não são descritas adaptações nos dispositivos.

Karadogan et al. (2010) modificaram a caneta stylus de um dispositivo Phantom Omni para acomodar os dedos dos usuários, além de ser capaz de obter forças de até $1.25 \mathrm{~N} / \mathrm{mm}$. Esta modificação permitiu que os braços mecânicos do dispositivo ficassem posicionados de forma ortogonal para a manipulação da maioria das superfícies virtuais, pois o dispositivo tem a maior rigidez no eixo y, ou seja, no movimento vertical do dedo.

Everett et al. (2009) também adaptaram o dispositivo Phantom Omni de forma a acomodar o dedo do usuário para a simulação do procedimento de toracostomia com tubo. Esta adaptação consistiu na construção de um artefato físico que, quando acoplado 
à caneta stylus do dispositivo, oferece aos usuários retorno tátil na ponta do dedo durante a palpação de uma superfície, além de uma sensação de compressão no procedimento de inserção do dedo no corpo.

\subsubsection{Dispositivo Falcon}

O Falcon é um dispositivo háptico fabricado pela empresa americana Novint (NOVINT..., 2015), originalmente concebido com o intuito de substituir o mouse em videogames e outras aplicações. Contudo, ele também passou a ser explorado como um dispositivo háptico, dado que oferece três graus de liberdade e $9 \mathrm{~N}$ de retorno máximo de força.

De acordo com Coles, Meglan e John (2011), por alguns anos ele foi considerado o dispositivo comercial com três graus de liberdade com menor custo no mercado, e, por isso, foi adotado nos simuladores desenvolvidos em (COLES; MEGLAN; JOHN, 2011) e (ROKE et al., 2013). Em ambos os trabalhos, o dispositivo foi adaptado de alguma maneira, e foi utilizado em conjunto com outro dispositivo, em decorrência de ser um dispositivo bastante simples, o que justifica o seu baixo custo.

\subsubsection{Dispositivos e técnicas de visualização}

Nos trabalhos analisados, verificou-se que o retorno visual ainda sofre com poucas inovações, visto que apenas dois deles empregaram o uso de HMD nas simulações propostas. Alguns deles mencionaram que utilizaram monitores CRT (Cathodic Ray Tube) ou LCD (Liquid Crystal Display), enquanto os demais sequer fizeram menção do dispositivo utilizado.

No que concerne a técnicas de esteroscopia utilizados na modelagem tridimensional dos objetos virtuais, o mais mencionado foi o de anaglifos, uma técnica muito comum nos trabalhos de simulação. Não foi exposto o desenvolvimento ou aplicação de nenhuma nova técnica de estereoscopia nos trabalhos analisados.

\subsubsection{Pontos de contato}

Na análise dos dispositivos utilizados nos trabalhos verificou-se que os dispositivos de um ponto de contato foram os mais utilizados, representando $71 \%$ do total. Por um 
lado, este domínio mostra que a maioria dos trabalhos teve que abdicar da robustez dos dispositivos mais caros, refletindo em trabalhos que talvez possam não ter atingido o objetivo proposto. Contudo, em face das avaliações positivas recebidas pela grande maioria deles, pode-se constatar que a ausência de pontos de contato não apresentou um efeito negativo na usabilidade das ferramentas, pois elas cumpriram seus objetivos com sucesso. Como citado anteriormente, este fato é corroborado por Lee et al. (2013), os quais afirmam que um dispositivo com apenas um ponto de contato é suficiente para que o usuário possa estudar a rugosidade da pele.

Pode-se afirmar que ainda que os dispositivos de um ponto de contato não sejam os ideais para a simulação mais realista e imersiva do exame de palpação, o uso deles pode complementar o aprendizado do usuário, visto que a sensação do toque necessária para que as habilidades sejam desenvolvidas não é perdida com o uso de um dispositivo menos robusto.

\subsection{Discussão sobre os trabalhos incluídos}

A análise dos trabalhos incluídos permitiu verificar que o crescimento de pesquisas na área de simulações de procedimentos de palpação deve-se principalmente às restrições encontradas para a execução de treinamentos reais. As restrições são relacionadas tanto a cenários quanto a recursos de treinamento, que muitas vezes são limitados ou insuficientes para todos que necessitam fazê-lo, como destacado em (COLES; MEGLAN; JOHN, 2011) e (GRECHENIG et al., 1999).

Na área de palpação cirúrgica, uma das dificuldades apontada nos trabalhos é a de ausência de tato durante cirurgias que demandam esta sensação (TALASAZ; PATEL, 2012). Na área de palpação veterinária, especificamente na bovina, o número de exames por animal é limitado por diretrizes, o que reduz a oportunidade de treinamento para estudantes (BAILLIE et al., 2005). Esta limitação também ocorre com a palpação em humanos, cujo número limitado de voluntários e cadáveres pode não proporcionar oportunidades suficientes de treinamento para os estudantes.

Neste cenário, os simuladores virtuais tornam-se um forte aliado para o treinamento de procedimentos de palpação. No entanto, ainda que muito avanços tenham sido feitos nos últimos anos no campo de sistemas hápticos aplicados a ambientes virtuais, ainda há uma distância considerável de uma representação fiel dos aspectos cinestésicos e táteis 
da sensação de tato humano. Isto também é um fator que contribui para a pesquisa de métodos que melhorem a percepção do tato.

Uma das principais inovações observadas diz respeito às adaptações realizadas nos dispositivos hápticos, que, apesar de não serem os ideais para a simulação, tiveram seu potencial aproveitado com o auxílio de aparatos físicos anexados à ferramenta, como realizado por Everett et al. (2009) e Karadogan et al. (2010). Outra inovação interessante foi o desenvolvimento de ferramentas com a capacidade de auxiliar os usuários na execução dos movimentos, corrigindo-os de acordo com os movimentos de profissionais (BAILLIE et al., 2010). Estas iniciativas, além de oferecerem liberdade aos usuários, minimizam a necessidade de um instrutor para acompanhar o treinamento e avaliar o desempenho.

Em relação aos métodos utilizados para deformação e retorno de força, observou-se que houve poucas propostas de novos métodos. Na verdade, como exposto anteriormente, o foco manteve-se nos métodos de elementos finitos e massa-mola, como em (FRISOLI; BORELLI; BERGAMASCO, 2005), no qual são feitas adaptações à abordagem multirresolução do método dos elementos finitos.

O uso de diferentes técnicas em um mesmo trabalho foi verificada somente em (LUBOZ et al., 2013), no qual os autores utilizam os métodos em partes diferentes do simulador: na estação de trabalho responsável pela simulação do procedimento de punção foi utilizado o método dos elementos finitos, enquanto na estação de trabalho na qual são realizadas a manipulação da agulha e a cateterização, é aplicado o método massa-mola. Os autores explicam que o método massa-mola, por ser computacionalmente mais eficiente, é aplicado na estação de trabalho mais complexa, enquanto na outra o método dos elementos finitos no contexto da punção com agulha é mais apropriado.

Em relação aos dispositivos verificou-se um domínio do dispositivo Phantom, adotado em mais da metade dos trabalhos. Este dispositivo, em todas as suas variações, oferece apenas um ponto de contato, e isto permite afirmar que, com exceção de alguns dispositivos adaptados, a maioria dos trabalhos incluídos considera a interação por meio de apenas um ponto de contato, ou seja, apenas um dedo é utilizado, ou é utilizada toda a mão para segurar o dispositivo. Isto pode prejudicar o retorno tátil, e, consequentemente, a capacidade do profissional de discernir a rigidez de um nódulo com o tato dos dedos. Esta limitação constitui um problema, pois, devido ao custo dos dispositivos, pesquisadores adotam dispositivos que não atendem plenamente aos requisitos necessários para construir um simulador realista, podendo comprometer a experiência do usuário. 
Em consequência disso, o aprendizado também pode ser prejudicado em simuladores de treinamento. Um dispositivo háptico inadequado para um determinado sistema torna-se um obstáculo no sentido de não permitir que seja explorado o potencial completo do esforço computacional e de desenvolvimento empregado no projeto. A iniciativa de adaptação do Phantom Omni, ou o uso de dois dispositivos Phantom Premium 1.5, são soluções pontuais que se mostraram inovadoras, interessantes e eficientes para o contexto dos seus projetos, mas que poderiam ser aprimoradas com o objetivo de oferecer uma experiência de treinamento mais completa e fiel ao usuário, complementando ainda mais seu aprendizado.

A preocupação com a representação realista da sensação de toque é perceptível na maioria dos trabalhos, por meio do desenvolvimento de diferentes modelos de tecido mole, utilizando diferentes técnicas. Basafa, Sefati e Okamura (2011), em particular, realizaram a medição das curvas de força-deformação de tecidos moles reais para calibrar este modelo, a fim de desenvolver um modelo massa-mola para simulação de tecidos moles, cuja validação junto aos usuários teve uma resposta positiva. Em geral, todos os outros trabalhos que apresentam algum tipo de experimento de validação da ferramenta ou técnica desenvolvida, buscam validar junto aos indivíduos a sua capacidade de percepção de sensação de toque.

A área de visualização, em particular, foi pouco abordada nos trabalhos, sendo que em alguns deles, o dispositivo de visualização utilizado sequer era mencionado. Alguns simuladores não necessitam do dispositivo, dado que a visão é obstruída no procedimento. No entanto, continua sendo bastante interessante incluí-la mesmo assim, como no caso do simulador de palpação retal para detecção de câncer de próstata, pois a interação e o aprendizado, por consequência, são enriquecidos com a informação visual da qual o profissional não disporia no mundo real. Também é válido ressaltar que um trabalho fez o uso do HMD no seu sistema de simulação, enquanto outro adaptou um monitor LCD para exibir o ambiente virtual de uma maneira mais condizente com a forma como o procedimento é realizado. Entretanto, nos demais trabalhos que citaram dispositivos, os mesmos são posicionados da forma tradicional, sem se preocupar com a posição que os médicos naturalmente assumem para fazer os exames. Isto é uma preocupação que deve ser analisada, dado que o sentido da visão pode ter importância similar ao toque para tornar a interação mais realista. Em decorrência disso, este sentido deve complementar o aprendizado da maneira mais fiel possível, aproximando o procedimento virtual do real. 


\subsection{Considerações Finais}

Algumas áreas exigem que o indivíduo passe por um treinamento virtual antes de realizar o procedimento real, como a área de aviação (NUNES; MACHADO; MORAES, 2014). Na simulação de procedimentos na área de saúde ainda não existe uma obrigatoridade, mas estudos comprovam que treinamentos virtuais contribuem para a diminuição de erros em procedimentos reais. Todavia, para que este objetivo seja alcançado a ferramenta deve oferecer o realismo necessário para um aprendizado completo.

A palpação constitui um ato importante na detecção de muitas anomalias em exames reais, visto que muitos procedimentos médicos são frequentemente precedidos ou acompanhados por esta prática. Mesmo em vista da importância desta técnica, a mesma continua sendo pouco explorada em procedimentos virtuais. Isto decorre do desafio que existe em reproduzir a sensação de tato com realismo, porque o tato em si a simulação da sensibilidade que o tato humano fornece tem requisitos difíceis de serem atingidos (ROBLES-DE-LA-TORRE, 2006).

Desta forma, devem ser estudadas maneiras de melhorar o realismo, assim como as preocupações computacionais inerentes, como a eficiência de algoritmos de colisão e deformação, a precisão dos dispositivos hápticos, o paralelismo demandado por estes recursos, entre outras. A maioria dos estudos conduzidos está na área de procedimentos cirúrgicos, sendo percebida a adoção de técnicas e ferramentas muito semelhantes entre as áreas. Tal fato favorece a perspectiva de reuso de software, contribuindo para o desenvolvimento mais rápido de trabalhos nesta área de aplicação. 


\section{Metodologia}

Como mencionado no capítulo introdutório deste documento, o objetivo principal do trabalho consiste em desenvolver um simulador de exame de palpação mamária com retorno háptico realista, que permita a definição dos parâmetros de retorno de força corretos para a simulação do procedimento.

O presente capítulo detalha a metodologia utilizada no desenvolvimento do simulador de palpação mamária. Inicialmente foi implementado um protótipo a fim de verificar a viabilidade da abordagem usada para implementação. Este protótipo foi avaliado por profissionais da área de Computação com a finalidade de verificar a percepção da sensação háptica. Uma vez corrigidas as limitações indicadas na avaliação e comprovada a viabilidade da abordagem, o protótipo foi expandido para contemplar os diversos parâmetros envolvidos na simulação de casos com realismo. O resultado final foi avaliado por uma especialista (médica mastologista).

Na seção 4.1 deste capítulo é descrita a metodologia para a implementação do protótipo do simulador e na seção 4.2 é apresentada a metodologia utilizada para construir a versão final do simulador.

\subsection{Desenvolvimento do protótipo}

O processo de desenvolvimento do protótipo contemplou três etapas principais: modelagem, na qual foi realizada a construção dos modelos virtuais utilizados no AV; pesquisa e definição dos parâmetros de retorno de força utilizados na aplicação; e implementação de interação, que trata da programação dos parâmetros no protótipo. Cada uma destas etapas é descrita nas subseções a seguir.

\subsubsection{Dispositivo háptico e modelagem de objetos}

Primeiramente, definiu-se que o dispositivo háptico a ser utilizado na pesquisa seria o Phantom Omni, cujos aspectos de portabilidade e fácil utilização, aliados aos sensores de posição com seis graus de liberdade, fazem dele um dispositivo com uma boa relação custo-benefício. 
O simulador aproveitou a estrutura fornecida pelo Virtual Medical Training (ViMeT), um framework de RV orientado a objetos para treinamento médico, desenvolvido na linguagem Java, e que permite criar a estrutura básica de ambiente virtual para treinamento de exames de biópsia, fornecendo as funcionalidades de deformação, detecção de colisão e estereoscopia (OLIVEIRA; NUNES, 2010).

Além disto, a ferramenta oferece a possibilidade de integração com vários dispositivos convencionais e não-convencionais, sendo destacada a integração ao dispositivo háptico Phantom Omni, que foi utilizado neste trabalho. Outra vantagem do uso do framework ViMeT diz respeito à disponibilidade dos objetos virtuais, os quais já estão inclusos na ferramenta.

No presente simulador, em particular, foi reutilizado o objeto virtual que simula a mama (Figura 17) para realizar a interação com o usuário e acrescentado um objeto para representar um nódulo.

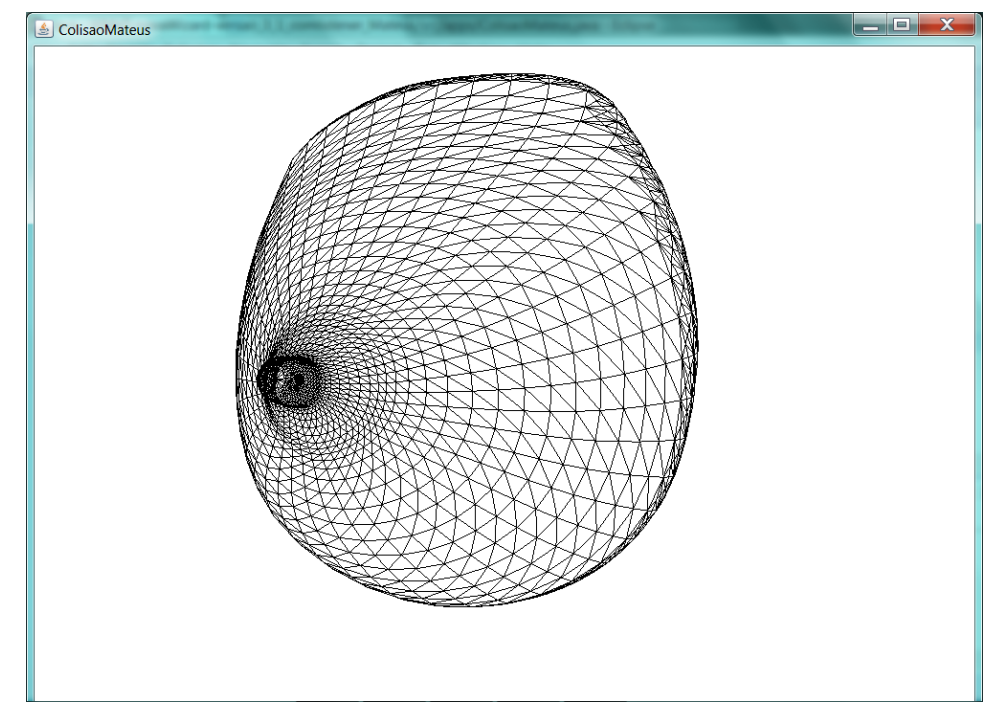

Figura 17 - Objeto virtual representando a mama.

Em se tratando da interação, o framework ViMeT implementa um AV para simulação de exames de punção utilizando uma seringa, o que não é plausível para o simulador de palpação. Por este motivo, este objeto foi substituído por um objeto virtual que simula uma mão humana (Figura 18). 


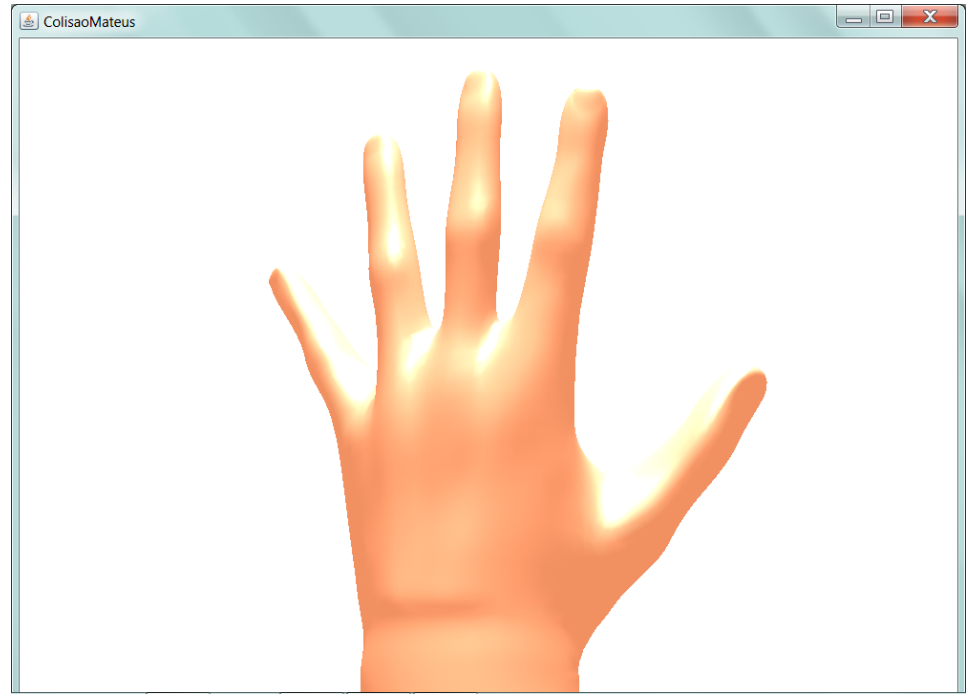

Figura 18 - Objeto virtual representando mão humana, com iluminação refletora e cor clara.

Para simular o nódulo foi utilizada uma primitiva geométrica da Application Programming Interface (API) Java 3D (JAVA3D, 2015) disponibilizada pela classe Sphere, a qual foi associada ao objeto virtual da mama. Na Figura 19 é exibido o nódulo virtual.

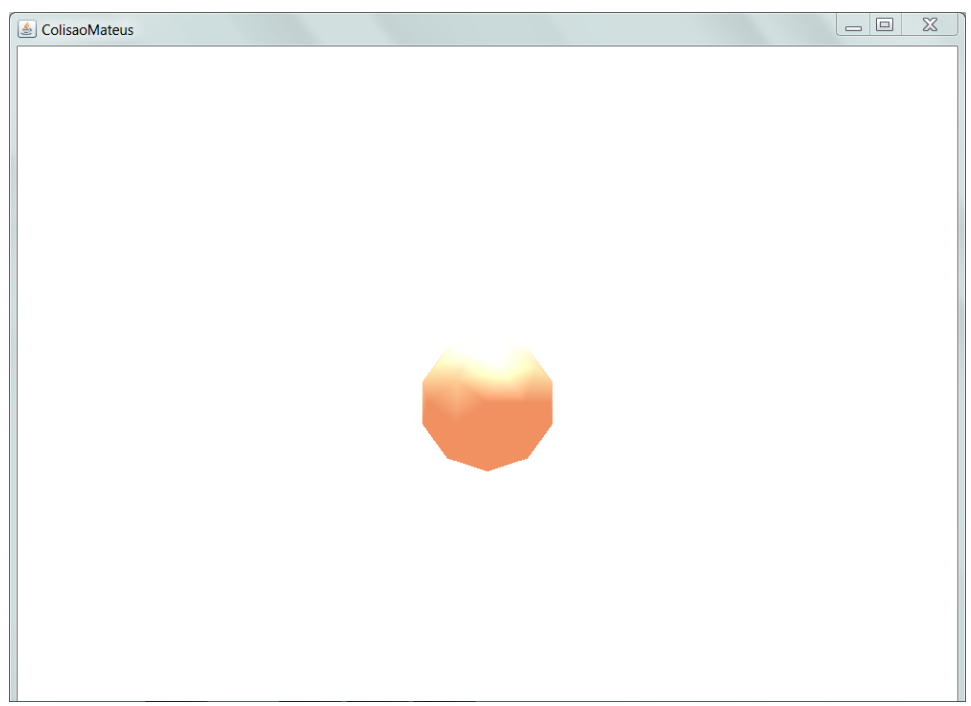

Figura 19 - Objeto virtual representando nódulo redondo.

Na Figura 20 é exibido o nódulo virtual dentro do objeto virtual da mama, que possui 1762 vértices e 3520 faces. A quantidade de vértices de um objeto permite a visualização de maior ou menor nível de detalhe envolvendo as deformações realizadas em um objeto virtual (OLIVEIRA; NUNES; BEZERRA, 2007). Conforme explorado com mais detalhes na avaliação descrita no capítulo 5, o número de vértices e faces não teve influência no tempo de resposta da aplicação para prover o retorno de força. 


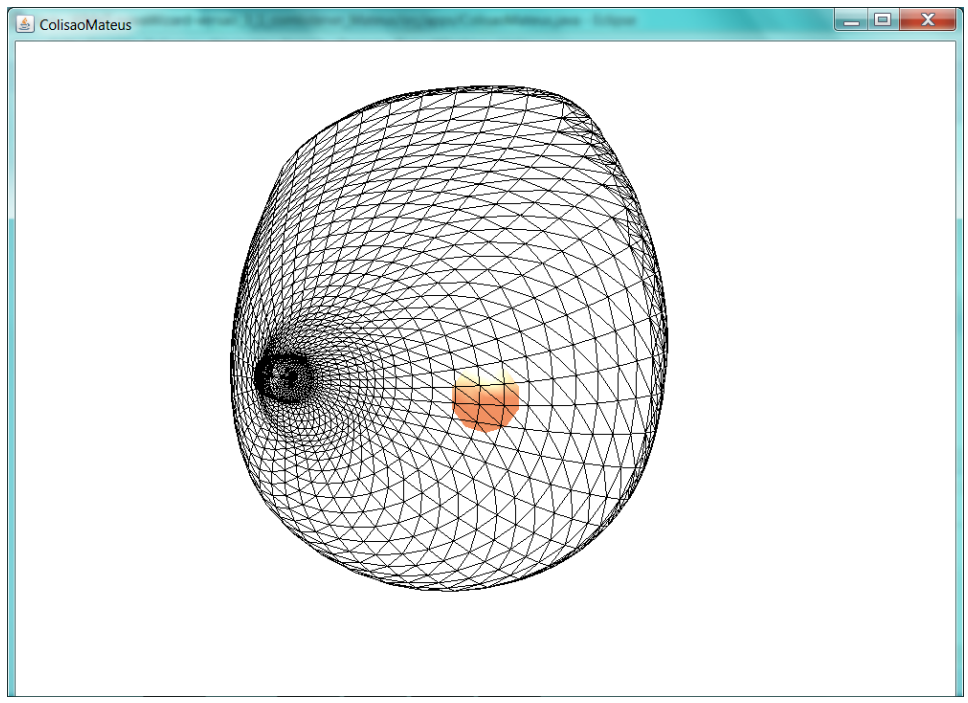

Figura 20 - Objeto virtual representando nódulo redondo dentro de uma mama virtual transparente.

\subsubsection{Pesquisa e definição dos parâmetros}

Após a criação do ambiente virtual, foi conduzida uma pesquisa com a finalidade de identificar os principais atributos dos nódulos mamários, especialmente no que concerne à sua rigidez e ao cálculo da força que deveria ser retornada pelo dispositivo háptico. Foram pesquisados os trabalhos que já realizaram a coleta destas informações, a fim de produzir um resumo dos principais padrões de tamanhos, rigidez e características de retorno de força, com o propósito de aplicá-los ao trabalho em questão.

O trabalho realizado em Jeon et al. (2010) utilizou dados coletados de dois modelos reais de mama, sendo que um deles continha um modelo real de nódulo, de maior rigidez, enquanto o outro referia-se à uma mama sem anomalias. O modelo sem nódulo apresentava elasticidade uniforme e sua rigidez medida em um deslocamento de $10 \mathrm{~mm}$ foi de 0.13 $\mathrm{N} / \mathrm{mm}$. O modelo com nódulo apresentou a mesma rigidez, exceto por um nódulo de raio de $12.5 \mathrm{~mm}$, cuja rigidez era de $0.54 \mathrm{~N} / \mathrm{mm}$. O nódulo estava alocado $25 \mathrm{~mm}$ abaixo da superfície do modelo da mama. Visto que os dados expostos anteriormente refletem as propriedades reais da mama, a força resultante de rigidez da mama foi definida em 0.13 N, e a força de rigidez do nódulo em 0.54 N. Estas forças deverão ser retornadas sempre que o usuário tocar a mama ou o nódulo, ou seja, quando o objeto virtual colidir com o modelo tridimensional da mama. 
De acordo com Almeida (2007), a força resistiva de penetração do tecido, no caso de um exame de punção, é simulada desde um ponto da punção inicial da pele até que o osso seja atingido, e sua direção é dependente da direção da agulha. O conceito da força resistiva pode ser aplicado ao exame de palpação, excluindo-se a situação da perfuração da pele. Assim, à medida que a mão do usuário pressiona a mama, percorrendo a distância da pele até o nódulo, o usuário sente a força de amortecimento total da pele, associada ao nódulo, até que a força de retorno do dispositivo alcance $3.3 \mathrm{~N}$, a força máxima retornada por ele (ALMEIDA, 2007). Isto indica ao usuário, por meio de um retorno de força mais intenso, que não será possível avançar além daquele ponto.

Detectar uma colisão é verificar o momento em que ocorre uma aproximação suficientemente pequena entre objetos de um AV a ponto de possibilitar a ocorrência de uma sobreposição entre eles. No caso do framework ViMeT, isto é feito a partir de um procedimento de detecção que utiliza um refinamento dos métodos BoundingBox e BoundingSphere, fornecidos pela API Java3D (OLIVEIRA; NUNES, 2010).

Este refinamento é recursivo, utilizando o conceito de Octrees, no qual o objeto tridimensional sobre o qual ocorre a detecção de colisão é dividido em octantes. Para continuar a subdivisão, é escolhido o octante não vazio cujo centro apresenta a menor distância euclidiana em relação ao centro do objeto que representa o instrumento médico virtual. Quando esta distância é menor que um valor pré-determinado, a precisão obtida pela colisão é aceitável. Este fluxo é exibido na Figura 21.

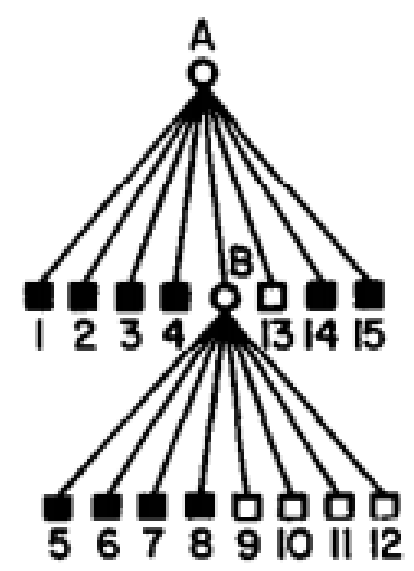

Figura 21 - Representação em árvore do processo de detecção de colisão utilizando Octrees. Fonte: (SAMET, 1989) 
Outro recurso importante da interação com o ambiente virtual no simulador é a deformação dos objetos tridimensionais, a qual simula a reação ao encontro entre dois ou mais objetos quando um deles é composto por tecidos flexíveis.

Neste trabalho foi adotado o método massa-mola para o desenvolvimento da classe que gera a deformação. O método massa-mola é baseado nas leis da Física e permite a representação de objetos por malhas, nas quais os vértices são nós de massa e as arestas entre vértices representam molas (CHOI et al., 2002). Normalmente, a mola apresenta uma força linear, a qual é baseada na lei de Hooke; contudo, molas não lineares também podem ser utilizadas com o propósito de simularem tecidos como a pele humana, cujo comportamento é não elástico (OLIVEIRA; NUNES, 2010). Este método foi utilizado por alguns dos trabalhos incluídos na RS, e descrito na subseção 3.4.2. Um exemplo de deformação da mama é exibido na Figura 22.

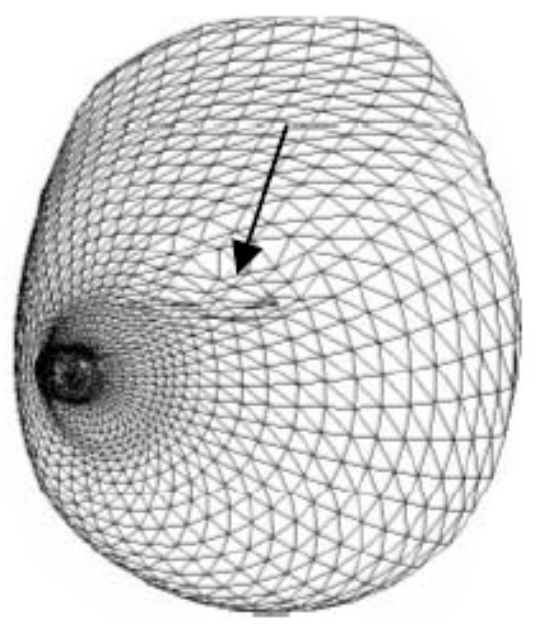

Figura 22 - Deformação da mama.

Quando é detectada uma colisão, quatro vetores são criados pela API do dispositivo háptico para armazenar os seguintes dados: posição atual do Phantom, velocidade de movimentação do dispositivo háptico posição em que o Phantom colidiu com o objeto virtual e quantidade do tecido que foi penetrado pelo dedo do usuário. A Tabela 1 detalha as informações destes vetores.

Enquanto se encontra em execução, o sistema de simulação executa repetidamente a atualização desses vetores com uma frequência de no mínimo $1000 \mathrm{~Hz}$, ou seja, a aplicação irá atualizar as forças, velocidades e posições renderizadas pelo dispositivo háptico pelo menos 1000 vezes por segundo. 
Tabela 1 - Vetores utilizados para cálculo da colisão

\begin{tabular}{|l|l|l|l|l|}
\hline Vetor & $\begin{array}{l}\text { Vetores do disposi- } \\
\text { tivo háptico utiliza- } \\
\text { dos }\end{array}$ & $\begin{array}{l}\text { Descrição do vetor } \\
\text { POSITION }\end{array}$ & $\begin{array}{l}\text { Tipos } \\
\text { do } \\
\text { vetor }\end{array}$ & $\begin{array}{l}\text { Unidade } \\
\text { de me- } \\
\text { dida }\end{array}$ \\
\hline PosAtual & $\begin{array}{l}\text { Armazena a posição atual } \\
\text { dos três eixos do dispo- } \\
\text { sitivo háptico de acordo } \\
\text { com base do dispositivo }\end{array}$ & $\begin{array}{l}\text { Double e } \\
\text { float }\end{array}$ & $\mathrm{mm}$ \\
\hline VelAtual & $\begin{array}{l}\text { HE_CURRENT_- } \\
\text { VELOCITY }\end{array}$ & $\begin{array}{l}\text { Armazena a velocidade } \\
\text { atual dos três eixos do dis- } \\
\text { positivo háptico }\end{array}$ & Double & $\mathrm{mm} / \mathrm{s}$ \\
\hline PosProxy & $\begin{array}{l}\text { HL_PROXY_POSI- } \\
\text { TION }\end{array}$ & $\begin{array}{l}\text { Armazena as coordena- } \\
\text { das dos três eixos em que } \\
\text { o dispositivo toca o ob- } \\
\text { jeto }\end{array}$ & $\begin{array}{l}\text { Double e } \\
\text { float }\end{array}$ & $\mathrm{mm}$ \\
\hline PenTecido & $\begin{array}{l}\text { HL_PROXY_ } \\
\text { POSITION } \\
\text { HD_CURRENT_ } \\
\text { POSITION }\end{array}$ & $\begin{array}{l}\text { Armazena a quantidade } \\
\text { de tecido penetrado }\end{array}$ & $\begin{array}{l}\text { Double e } \\
\text { float }\end{array}$ & $\mathrm{mm}$ \\
\hline
\end{tabular}

A força determinada pelos vetores é apresentada na equação 1. Esta equação consiste na somatória das forças de mola (spring) e amortecimento (damping) geradas pelo contato do objeto virtual controlado pelo dispositivo com o outro objeto virtual do AV.

A força de mola consiste na multiplicação da constante de mola do objeto (kSpring) pela quantidade de tecido penetrado, a qual é determinada pela subtração do ponto em que o objeto foi tocado e o ponto em que ele se encontra no momento (PosProxy - PosAtual). Este cálculo refere-se à Lei de Hooke, apresentada na equação 2.

A força de amortecimento, por sua vez, consiste na multiplicação da constante de amortecimento (kDamping) pela velocidade (VelAtual) aplicada no dispositivo. O fluxo completo das ações após a detecção de colisão é exibido no diagrama da Figura 23.

$$
\text { FTotal }=(k \text { Stiffness } \times(\text { PosProxy }- \text { PosAtual }))+-(k \text { Damping } \times \text { VelAtual })
$$

\subsubsection{Implementação e interação}

Considerando a modelagem e os parâmetros anteriormente apresentados, foi iniciada a próxima etapa do trabalho, que consistiu na inclusão dos cálculos supracitados na biblioteca da interface háptica do dispositivo Phantom, a HLAPI (Haptic Library API - 


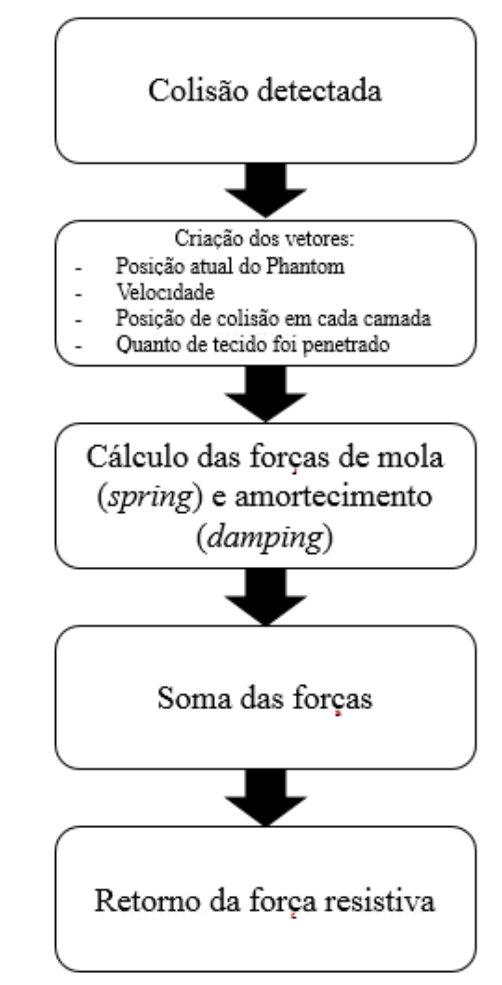

Figura 23 - Diagrama de ações após a detecção de colisão.

API do dispositivo háptico). Esta biblioteca lida com a detecção e resposta de colisão para renderização háptica de objetos e efeitos. Por isso, nela foram acondicionados os detalhes da implementação da detecção de colisão do instrumento médico virtual com a mama virtual e com o objeto virtual que representa o nódulo, representado modelado por uma primitiva esférica da linguagem de programação, como descrito na seção 4.1.1.

Um programa HLAPI utiliza funções do Open $G L$, que, por sua vez, é uma API livre com centenas de funções utilizadas para especificar objetos e operações necessários na construção de aplicações interativas tridimensionais (NEIDER; DAVIS; WOO, 1993). A HLAPI realiza as renderizações háptica e gráfica, com o mapeamento das coordenadas hápticas para o AV. Para a inclusão dos parâmetros correspondentes às forças de retorno especificadas anteriormente, foram feitas alterações na classe Haptic do framework ViMeT. Esta classe é responsável pela execução dos métodos nativos do dispositivo háptico e alterações na translação e rotação do objeto virtual, além de permitir o retorno de força. Na Figura 24, que exibe o diagrama de classes do framework ViMeT, é possível visualizar a classe Haptic associada à classe NativeHaptic, que contém os métodos nativos para acessar as funções da biblioteca OpenHaptics Toolkit. Nesta última, está inclusa a 
biblioteca HLAPI, bem como o arquivo $d l l$ que realiza a integração entre as linguagens Java e C.

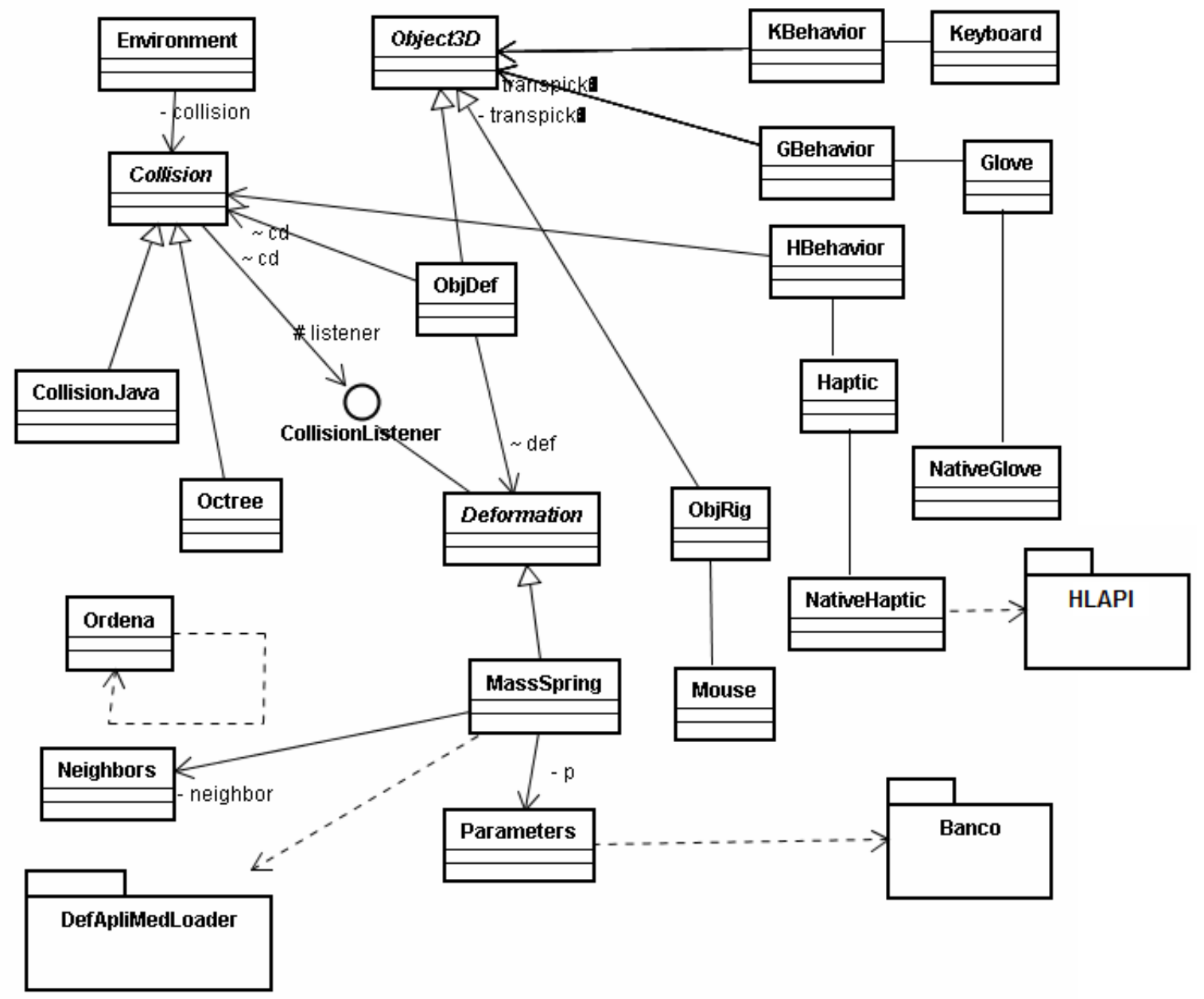

Figura 24 - Diagrama de classes do framework ViMeT.

O processo de interação desde a criação da aplicação até o retorno de força é exibido no diagrama da Figura 25. Neste diagrama é possível observar as etapas de interação, assim como as respectivas classes associadas a cada uma delas. Vale destacar que o primeiro passo da utilização se dá a partir da instanciação da classe Wizard, uma ferramenta do framework ViMeT, que permite a criação de aplicações customizáveis pelos usuários (OLIVEIRA; NUNES, 2010). A partir disto, a classe Environment é responsável pela criação do Ambiente Virtual e herda características da classe VirtualUniverse, da API Java3D. Em seguida, a classe Collision atua na detecção de colisão, por meio de uma interface denominada CollisionListener, a qual possui o método collisionPerformed, invocado quando ocorre uma colisão. 


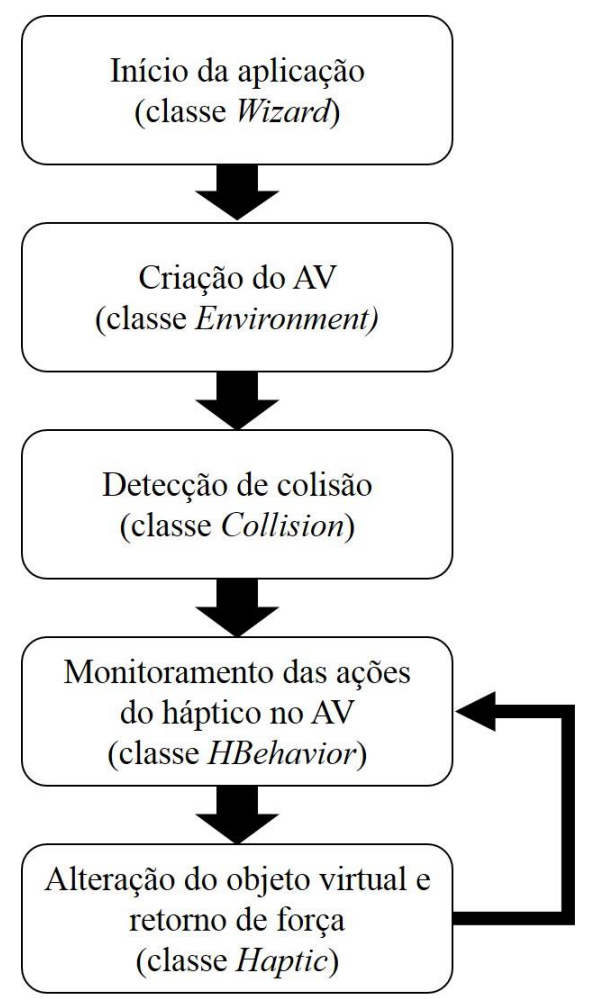

Figura 25 - Diagrama de interação do sistema com o dispositivo háptico.

A classe Haptic, responsável por realizar as transformações nos objetos virtuais, utiliza os métodos nativos da classe NativeHaptic, os quais, por sua vez, possuem uma classe estendida da classe HBehavior. Esta, por meio da classe WakeupOnElapsedFrames e dos métodos initialize e processStimulus, implementa um laço que verifica as informações do dispositivo háptico e mapeia-as para os objetos virtuais correspondentes. Por fim, para a geração da aplicação em si, foi utilizado um exemplo fornecido pela própria ferramenta Wizard do framework base. Assim, é necessário determinar os objetos a serem inseridos no AV, as características de visualização, colisão e deformação, para obter uma aplicação de treinamento plenamente funcional. A partir deste mecanismo, foi possível construir aplicações para validação da simulação de retorno háptico, a qual é apresentada no Capítulo 5.

\subsection{Versão final do simulador de palpação mamária}

Nesta seção são descritas as etapas relativas ao desenvolvimento do simulador final. Na subseção 4.2.1 é explicada a adaptação realizada no dispositivo háptico, com a finalidade de adequá-lo à situação identificada no mundo real. Na subseção 4.2.2 é apresentada a 
modelagem dos objetos virtuais utilizados no simulador que foram modificados em relação ao protótipo inicial. Na subseção 4.2.3 são apresentados os detalhes de implementação dos parâmetros de retorno de força.

\subsubsection{Adaptação do dispositivo háptico}

Conforme abordado na Seção 3.6, foram identificadas várias abordagens de adaptação dos dispositivos hápticos. Uma das mais comuns faz a substituição da caneta stylus por um dedal para palpação, como em Coles, Meglan e John (2011), no qual o dedo indicador é inserido para realizar a palpação. No entanto, no procedimento real de palpação mamária, ao menos dois dedos devem interagir com a superfície simulada.

Ullrich e Kuhlen (2012) mencionam que embora seja possível utilizar vários dispositivos hápticos para oferecer retorno háptico para vários dedos, o problema é que o uso de múltiplos dispositivos para uma mão causa a sobreposição de áreas de trabalho, o que limita o alinhamento dos dedos, além de resultar em maiores custos.

Na versão final do simulador, o dispositivo háptico Phantom Omni foi mantido como a ferramenta de interação do simulador. Contudo, como a interface original do dispositivo, que inclui uma caneta stylus, não representa o cenário real de um exame de palpação, o dispositivo foi adaptado de acordo com o trabalho de (ULLRICH; KUHLEN, 2012), que propõe a construção de uma extensão para o dispositivo.

Primeiramente, foram analisados os requisitos técnicos e médicos para a adaptação. Do ponto de vista técnico, a extensão deveria ser leve, dado que a caneta stylus pesa 25 gramas. A fim de atender aos requisitos relacionados à aplicação, ou seja, aproximar-se das ações executadas durante o procedimento médico, foi estabelecida uma base para os dedos indicador e médio, na qual apenas as pontas dos dedos deveriam estar em contato com o dispositivo. A base deveria estar coberta por uma borracha aderente para os dedos, a fim de fornecer uma sensação mais próxima da pele, assim como um elástico que permitisse a fixação dos dedos na superfície (ULLRICH; KUHLEN, 2012).

O design foi otimizado de forma a ser leve, enquanto é capaz de manter a estabilidade e durabilidade. Além disso, o tamanho e a forma da borracha foram ajustados para formatos médios de dedos. A construção utilizou placas de acrílico com $3 \mathrm{~mm}$ de espessura cortadas a laser (Figura 26). Espumas de borracha de $3 \mathrm{~mm}$ de espessura com uma superfície traseira adesiva foram usadas para fornecer um material de superfície de baixa rugosidade. 
Este material foi escolhido por causa da sua aderência, rugosidade que permite uma fricção próxima da pele e também devido às propriedades neutras de temperatura, pois o mesmo esquenta rapidamente quando ocorre o contato dos dedos.

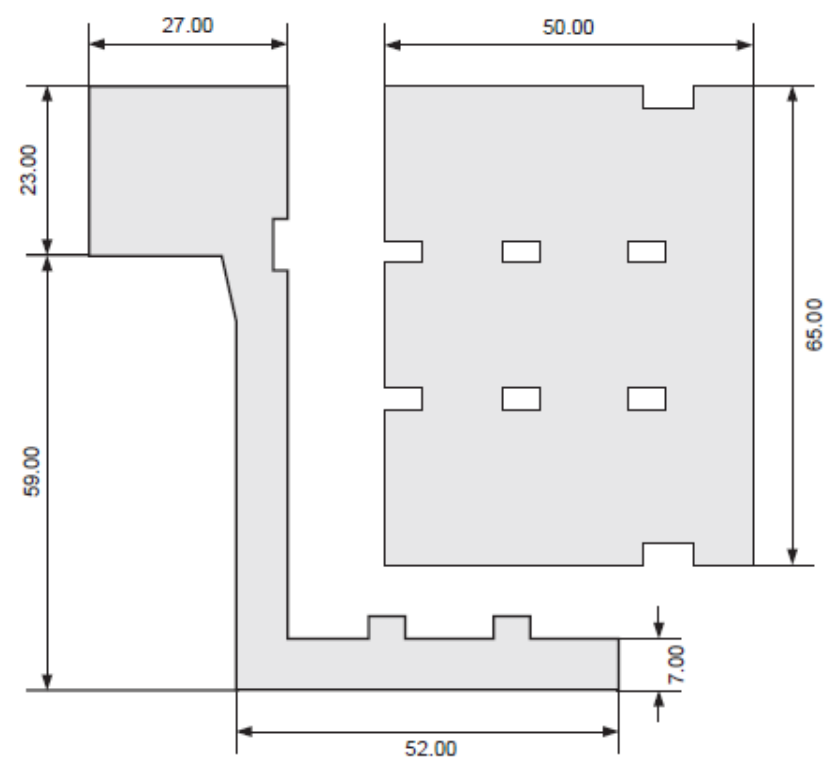

Figura 26 - Plano de corte para a extensão de acrílico: duas peças laterais (esquerda) e uma base (direita).

Fonte: (ULLRICH; KUHLEN, 2012)

A extensão completa pesa 30 gramas, e por causa da pequena diferença de peso em relação à caneta stylus padrão, não foi adicionada compensação de gravidade aos algoritmos de renderização de força. Na Figura 27 é possível observar a adaptação realizada no dispositivo.

\subsubsection{Modelagem dos objetos}

No que diz respeito aos objetos virtuais, foi reutilizado o objeto virtual que simula a mama para realizar a interação com o usuário. Para o nódulo também foi mantida a primitiva geométrica Sphere da API Java3D, a qual foi associada ao objeto virtual da mama, conforme apresentado previamente na seção 4.1.1.

Devido à sua importância no procedimento de simulação, o objeto virtual que representa o nódulo foi melhorado em relação ao objeto anterior, para simular as bordas referentes a casos de malignidade e benignidade. Sendo assim, foram anexadas ao nódulo virtual pequenas primitivas geométricas representando estas deformações. 


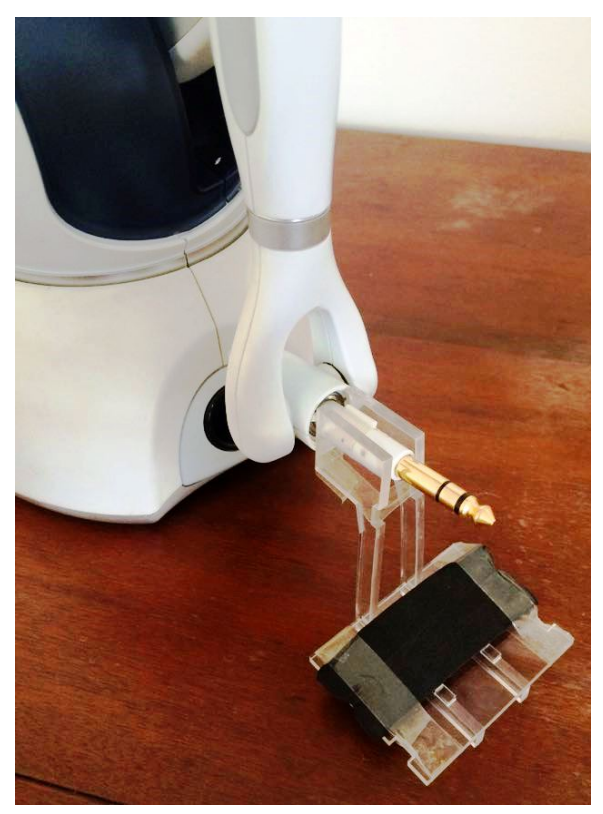

Figura 27 - Adaptação realizada no dispositivo háptico para realização da palpação

Em se tratando da interação, o objeto virtual que simula uma mão humana foi mantido, sem alterações em relação ao que foi utilizado no protótipo.

\subsubsection{Implementação dos parâmetros de retorno de força do nódulo}

Como mencionado anteriormente, a força resistiva para retorno de força do nódulo é calculada pela soma das forças de mola e amortecimento, conforme equação 1. A força de mola (spring) utilizada é a Lei de Hooke, descrita na Equação 2. Esta é a lei da física relacionada à elasticidade de corpos, empregada para calcular a deformação causada pela força exercida sobre um corpo, tal que a força é igual ao deslocamento da massa a partir do seu ponto de equilíbrio multiplicada pela constante de deformação do corpo, ou seja, o quanto este corpo oferece resistência a uma força aplicada sobre ele. Nesta equação, $k$ é a constante de deformação do corpo sobre o qual está sendo exercida a força, e $\Delta l$ é o deslocamento da massa a partir do seu ponto de equilíbrio. Para cada uma das características simuladas, foram definidas diferentes constantes para o retorno de força, apresentadas na Tabela 2.

$$
F=k \times \Delta l
$$

A força de amortecimento (damping), por sua vez, tem como principal utilidade a redução da vibração, já que ela está sempre apontando na direção oposta ao movimento 
sendo realizado. A equação 3 é a equação padrão de amortecimento, onde $b$ é a constante de amortecimento e $v$ é a velocidade exercida pelo usuário no dispositivo háptico.

$$
F=-b \times v
$$

\subsubsection{Contorno do nódulo}

Conforme apresentado na subseção 2.1.2, os nódulos relacionados à malignidade apresentam contornos com formato espiculado e aqueles relacionados à benignidade apresentam contornos arredondados.

Para a simulação das margens do nódulo com contornos arredondados, nada foi alterado em relação à forma previamente selecionada, isto é, os limites da superfície externa do objeto virtual foram mantidos (Figura 19).

Para a simulação do contorno espiculado foram adicionadas ao formato original várias primitivas esféricas. Desta maneira, buscou-se gerar uma sensação de irregularidade na superfície do nódulo, caracterizando assim, os limites mal definidos que podem estar relacionados a um possível fator de malignidade do nódulo sendo examinado.

Para cada um dos objetos virtuais representando irregularidades que foram adicionadas aos nódulos, também foi instanciado um objeto de colisão associado a ele. Isto é feito a partir da chamada do método setSchedulingBounds da classe responsável pela detecção de colisão, a CollisionJava. O parâmetro deste método é o objeto virtual para o qual deseja-se adicionar a detecção de colisão. Assim, no momento do toque da mão virtual com cada uma destas irregularidades, o usuário tem um retorno de força diferenciado indicando esta característica.

\subsubsection{Consistência do nódulo}

Conforme apresentado na subseção 2.1.2, os nódulos relacionados à malignidade apresentam consistência pétrea, isto é, mais dura, e aqueles relacionados à benignidade apresentam uma consistência fibroelástica, mais mole.

No que diz respeito à simulação da consistência, foi implementado um retorno de força inerente a cada um dos tipos existentes (pétreo e fibroelástico). Conforme definido 
anteriormente (subseção 4.2.3), para o retorno de força utilizou-se a Lei de Hooke, que considera a constante de deformação do material para determinar a força de retorno.

A fim de implementar uma força máxima a ser retornada para o usuário de maneira que fosse oferecida uma sensação realista, foram utilizadas constantes específicas para cada um dos tipos de consistência. Tais constantes foram definidas a partir de embasamento teórico (JEON et al., 2010), (JEON; CHOI; HARDERS, 2012) e testes empíricos realizados junto à médica mastologista, que auxiliou na adequação destas constantes às situações identificadas nos procedimentos realizados com pacientes reais. As constantes utilizadas para os dois tipos de nódulos são apresentadas na Tabela 2.

Tabela 2 - Constantes utilizadas para os nódulos.

\begin{tabular}{|l|l|l|}
\hline $\begin{array}{l}\text { Consistência } \\
\text { do nódulo }\end{array}$ & Constante & $\begin{array}{l}\text { Força máxima } \\
\text { retornada }\end{array}$ \\
\hline Fibroelástico & 0.004 & $0.3 \mathrm{~N}$ \\
\hline Pétreo & 0.008 & $0.6 \mathrm{~N}$ \\
\hline
\end{tabular}

\subsubsection{Tamanho do nódulo}

Conforme apresentado na subseção 2.1.2, o diâmetro médio dos nódulos encontrados foi de $2,56 \mathrm{~cm}$, sendo semelhante nos dois grupos (2,72cm nas benignas e 2,49 nas malignas). Sendo assim, não se pode afirmar que existe uma relação direta entre tamanho e patologia do nódulo.

A configuração do tamanho do nódulo que se deseja simular foi deixada a encargo do usuário, que deve preencher um campo de texto especificando o diâmetro em milímetros. O número inserido pelo usuário é utilizado como parâmetro no momento da instanciação do objeto Sphere. Na Figura 28 são exibidos três nódulos de diferentes tamanhos (escala alterada).

\subsubsection{Posição do nódulo na mama}

Conforme apresentado na subseção 2.1.2, o nódulo pode estar posicionado na mama a partir de duas perspectivas diferentes: área, que corresponde à localização do nódulo no que diz respeito ao posicionamento vertical/horizontal (eixos X e Y); e profundidade, que 


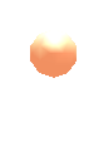

a)

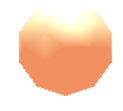

b)

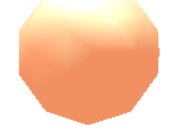

c)

Figura 28 - Três diferentes tamanhos de nódulos: a) $0.5 \mathrm{~cm}$; b) $1 \mathrm{~cm}$; c) $2 \mathrm{~cm}$.

corresponde ao plano profundo ou superficial da mama (eixo Z). A Tabela 3 diferencia as diferentes possibilidades de posicionamento do nódulo na mama.

Tabela 3 - Posicionamento do nódulo na mama

\begin{tabular}{|l|l|}
\hline Posição & Local \\
\hline \multirow{4}{*}{ Área } & Quadrante superior externo (Upper Outer) \\
& Quadrante superior interno (Upper Inner) \\
& Quadrante inferior externo (Lower Outer) \\
& Quadrante inferior interno (Lower Inner) \\
& Central \\
\hline \multirow{2}{*}{ Profundidade } & Plano superficial \\
& Plano profundo \\
\hline
\end{tabular}

A partir da seleção da área da mama pelo usuário, a posicionamento dentro do quadrante em questão do nódulo é determinado por meio de um sorteio dos valores dos eixos $\mathrm{X}$ e $\mathrm{Y}$, de acordo com o respectivo intervalo de valores do quadrante. Os quatro possíveis intervalos estão discriminados na Tabela 4, adotando como referência a mama esquerda. Os sinais dos intervalos mudam caso seja escolhida a mama direita.

Tabela 4 - Intervalos de valores de posicionamento (mama esquerda)

\begin{tabular}{|l|l|}
\hline Local & Intervalo \\
\hline Quadrante superior externo & Eixo X: maior valor negativo e zero; \\
(Upper Outer) & Eixo Y: zero e maior valor positivo \\
\hline Quadrante superior interno & Eixo X: zero e maior valor positivo; Eixo \\
(Upper Inner) & Y: zero e maior valor positivo \\
\hline Quadrante inferior externo & Eixo X: maior valor negativo e zero; \\
(Lower Outer $)$ & Eixo Y: zero e maior valor negativo \\
\hline Quadrante inferior interno & Eixo X: zero maior valor negativo; Eixo \\
(Lower Inner $)$ & Y: zero e maior valor negativo \\
\hline
\end{tabular}

Este posicionamento é, então, definido como o parâmetro correspondente aos eixos X e Y de um objeto Vector3d, que correspondem respectivamente à movimentação horizontal e 
vertical de um objeto no AV. Este objeto Vector3d, por sua vez, é utilizado como parâmetro do método setTranslation do objeto Transform3D, que lida com todas as alterações de um objeto virtual no AV. Assim, considera-se que o AV é um sistema de coordenadas cartesiano, e a partir de um conjunto de coordenadas X, Y e Z, este método mapeia um objeto virtual nestas coordenadas do plano tridimensional.

O posicionamento em profundidade, por sua vez, determina se o nódulo estará no plano superficial ou no plano profundo da mama. No contexto da implementação, ele é definido a partir do terceiro parâmetro do objeto Vector3d, o qual corresponde ao eixo Z do AV.

Na Figura 29 é apresentado um diagrama que detalha o fluxo utilizado para a definição do posicionamento do nódulo na mama virtual.

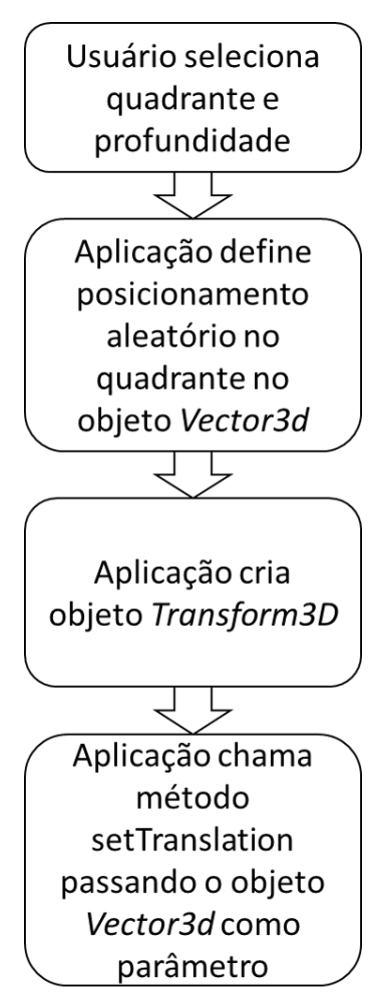

Figura 29 - Fluxo de definição do posicionamento do nódulo.

\subsubsection{Mobilidade do nódulo}

Conforme apresentado na subseção 2.1.2, uma das características mais evidentes de uma possível patologia de um nódulo é a sua aderência ao plano no qual ele está posicionado 
na mama. Logo, sua mobilidade é um fator muito importante para um eventual diagnóstico prévio e, portanto, representa uma situação essencial de treinamento.

O instrutor responsável pela configuração dos casos de treinamento pode escolher se o nódulo deve ser móvel ou não. Sendo móvel, quando aplicada uma força ao nódulo, sua posição é alterada em função da velocidade e da força que estão sendo aplicadas no dispositivo. A Equação 4 descreve o cálculo adotado para o cálculo da nova posição $(P n)$ para um nódulo configurado como móvel. Pn é calculada a partir da somatória de dois valores: a multiplicação entre a posição atual do nódulo $(P a)$ e a força exercida pelo usuário sobre o nódulo $(F)$; e a multiplicação entre a velocidade exercida pelo usuário no dispositivo háptico $(v)$ e a constante de deformação do nódulo $(k)$, que é determinada pela consistência definida previamente pelo usuário.

$$
P n=P a \times F+(-v \times k)
$$

A movimentação do nódulo ocorre a partir da modificação da posição do nódulo no AV, por meio do método setTranslation, anteriormente apresentado no contexto do posicionamento do nódulo na mama.

A Equação 5 descreve o cálculo adotado para o retorno de força $(F r)$ para um nódulo configurado como móvel. A equação consiste na somatória entre a força exercida pelo usuário no dispositivo háptico sobre o nódulo $(F e)$ e o resultado da multiplicação entre a velocidade exercida pelo usuário no dispositivo háptico $(v)$ e a constante de deformação do nódulo $(k)$, que é determinada pela consistência definida previamente pelo usuário (seção 4.2.5).

Caso o nódulo seja configurado para não ser móvel, ele não se movimenta e a força retornada ao usuário aumenta à medida em que o usuário aplica uma força mais intensa sobre o nódulo, seguindo a Equação 5, até atingir a força máxima retornada pelo dispositivo, de $3.3 \mathrm{~N}$.

$$
F r=F e+(v \times k)
$$

Neste caso, também é exibido um alerta (Figura 30) no simulador, de forma a comunicar que a força sendo exercida é tão alta que em uma situação real poderia estar causando um desconforto extremo ao usuário 


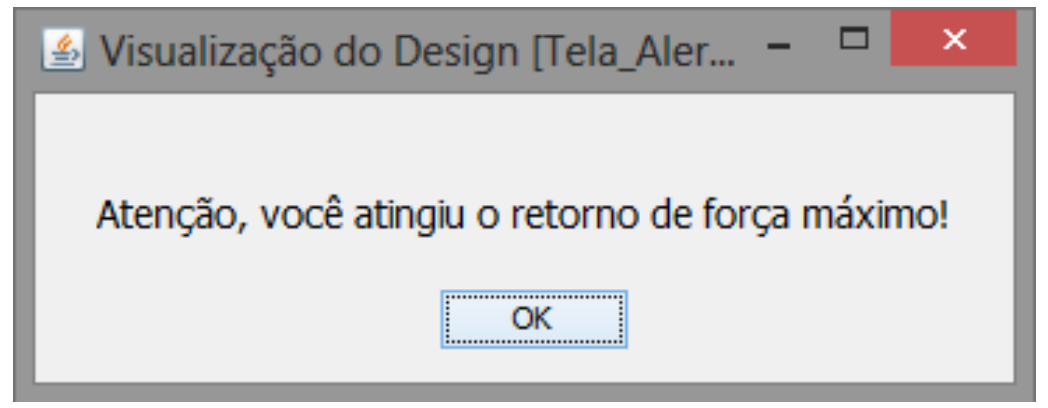

Figura 30 - Alerta de força máxima no simulador.

\subsubsection{Interfaces do simulador}

A interação do instrutor responsável pela geração dos diferentes casos com o simulador ocorre por meio de três interfaces, que são detalhadas a seguir, obedecendo fluxo de interação apresentado no diagrama da Figura 31.

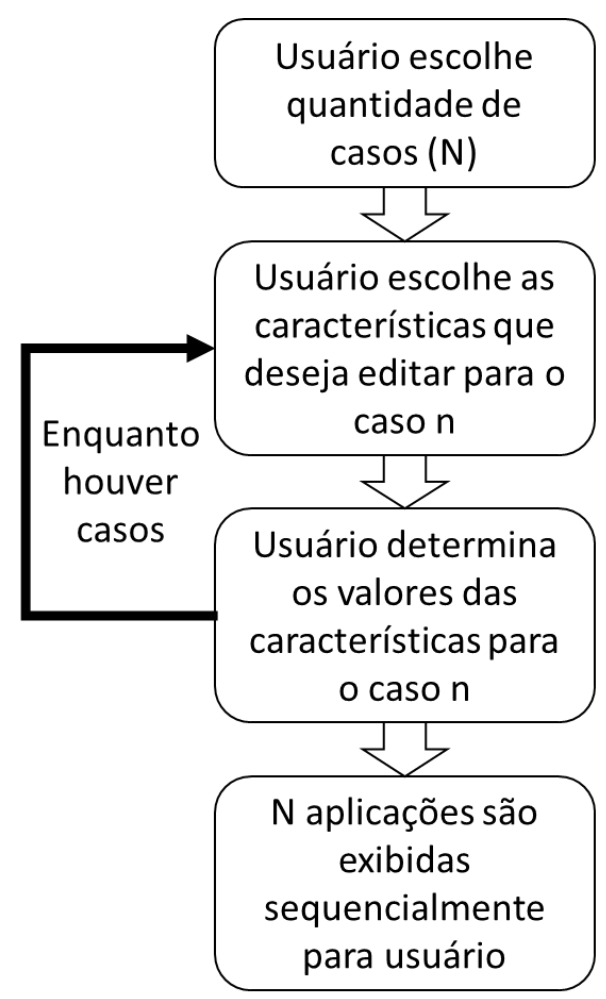

Figura 31 - Fluxo de interação do instrutor com o simulador.

Na primeira interface, apresentada na Figura 32, o instrutor seleciona a quantidade de casos que deseja simular.

Em seguida, é apresentada uma interface na qual o instrutor pode selecionar as características para as quais ele deseja definir os parâmetros a serem simulados, de acordo com a Figura 33. 


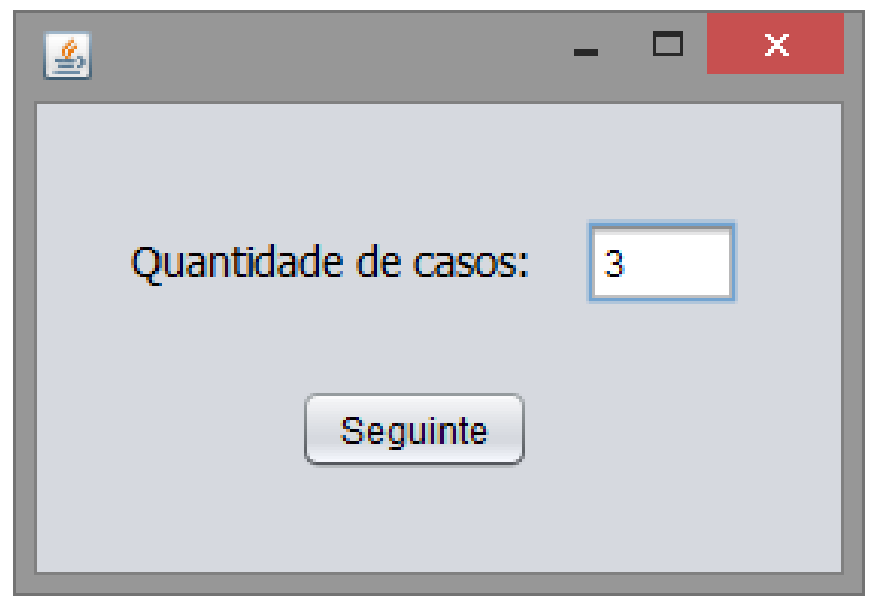

Figura 32 - Interface para definição da quantidade de casos.

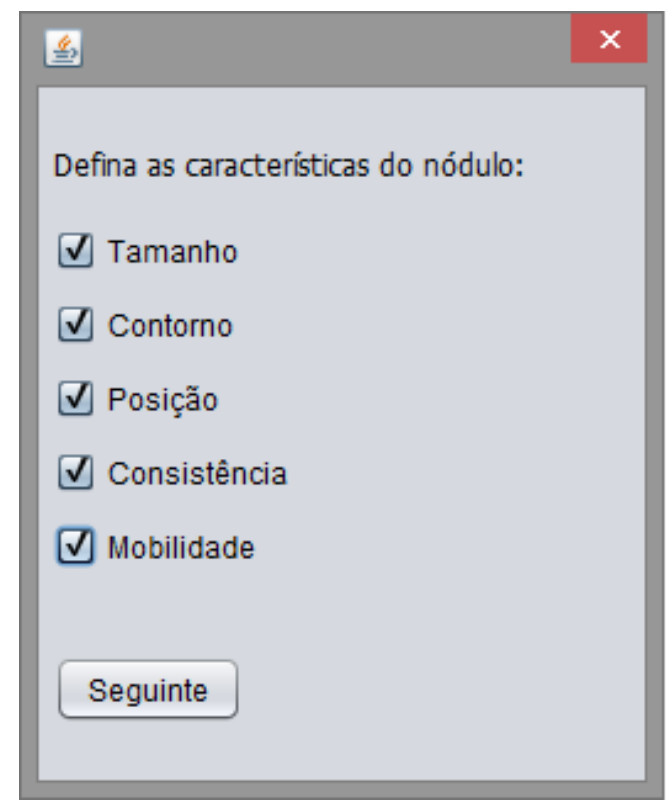

Figura 33 - Interface para escolha das características.

As características disponíveis para seleção são listadas juntamente da respectiva descrição na Tabela 5 .

Tabela 5 - Características disponíveis para seleção

\begin{tabular}{|l|l|}
\hline Característica & Descrição \\
\hline Tamanho & Tamanho do nódulo em milímetros \\
\hline Contorno & Formato das margens do nódulo \\
\hline Posição & $\begin{array}{l}\text { Quadrante da mama e plano no qual estará } \\
\text { localizado o nódulo }\end{array}$ \\
\hline Consistência & $\begin{array}{l}\text { Densidade do nódulo que determina o re- } \\
\text { torno de força quando pressionado }\end{array}$ \\
\hline Mobilidade & $\begin{array}{l}\text { Capacidade do nódulo de movimentar-se } \\
\text { pela mama quando pressionado }\end{array}$ \\
\hline
\end{tabular}


A seguir, o instrutor pode selecionar os parâmetros para as características escolhidas, conforme mostrado na Figura 34.

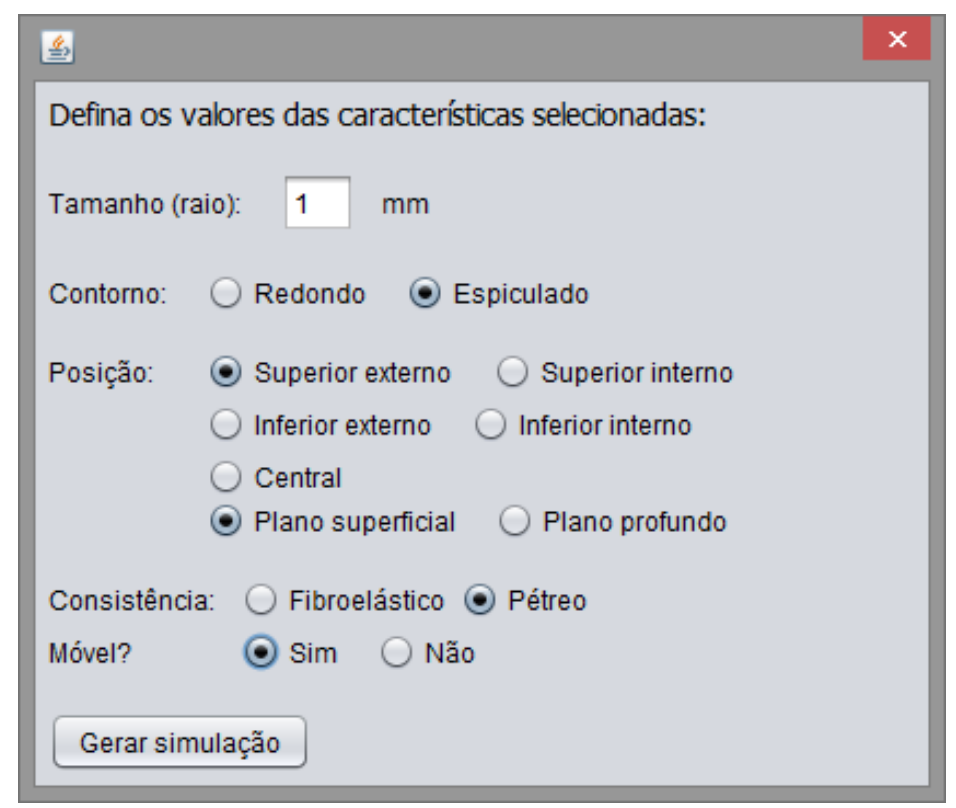

Figura 34 - Interface para definição dos parâmetros.

Os parâmetros disponíveis para configuração são listados juntamente da respectiva descrição na Tabela 6 .

Tabela 6 - Parâmetros disponíveis para configuração

\begin{tabular}{|l|l|}
\hline Característica & Parâmetro \\
\hline Contorno & Redondo \\
& Espiculado \\
\hline \multirow{2}{*}{ Posição (Quadrante) } & Superior externo \\
& Superior interno \\
& Inferior externo \\
& Inferior interno \\
& Central \\
\hline Posição (Profundidade) & Plano superficial \\
\hline Consistência & Plano profundo \\
\hline \multirow{2}{*}{ Mobilidade } & Fibroelástico \\
& Pétreo \\
\hline
\end{tabular}

As etapas de seleção das características e configuração dos parâmetros são repetidas até que se esgotem o número de casos configurados pelo instrutor na primeira interface. Por fim, as simulações são exibidas sequencialmente ao estudante que está treinando o procedimento. 
Alguns exemplos de simulações são expostos a seguir. Na Figura 35 é exibido um exemplo de uma das aplicações configuradas, na qual a estrutura do nódulo não é visível.

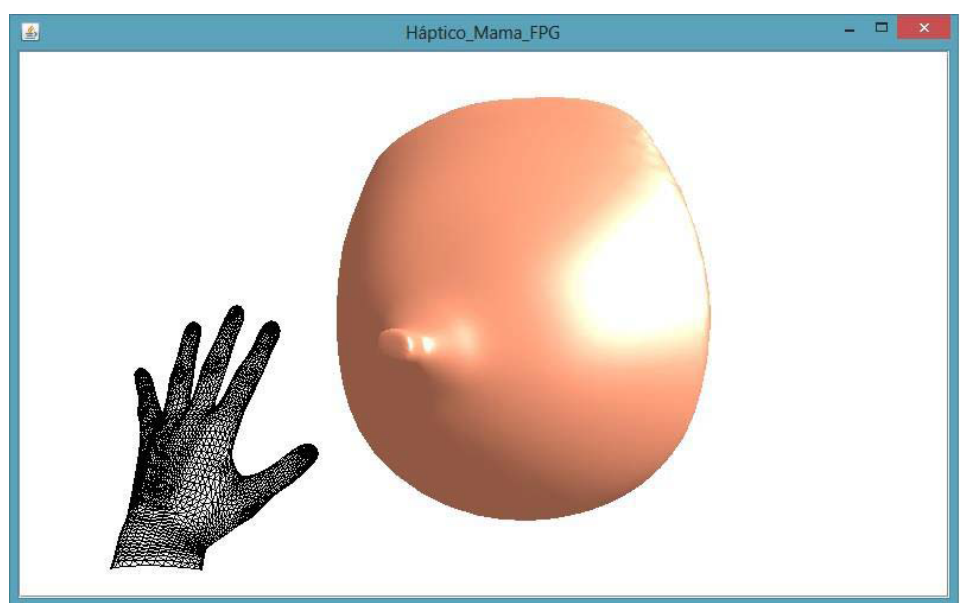

Figura 35 - Simulação do exame de palpação da mama com a estrutura do nódulo invisível. 


\section{Resultados e Discussões}

Conforme mencionado no capítulo anterior, um dos diferenciais que se buscou atingir ao longo deste trabalho foi a condução de avaliações da ferramenta nas duas etapas: desenvolvimento do protótipo e desenvolvimento seguida do simulador final. A avaliação do protótipo, realizada com indivíduos leigos foi útil para mostrar a viabilidade do retorno de força como indicativo da existência de uma estrutura de interesse simulada, e é apresentada na seção 5.1. Já a avaliação da ferramenta final, conduzida com uma profissional de medicina, especializada no assunto, é descrita na seção 5.2.

\subsection{Avaliação do protótipo}

A avaliação do simulador foi realizada com quatro indivíduos, todos do sexo masculino. As idades variaram entre 23 e 27 anos, sendo que todos já haviam concluído o ensino superior. Todos os indivíduos apresentavam formação na área de Computação, sendo totalmente leigos em relação à área de exame de palpação da mama ou qualquer tipo de simulação do mesmo. Contudo, todos os participantes já haviam tido algum tipo de interação com um sistema de RV, particularmente com jogos e outros tipos de simuladores, cuja interação ocorria por meio de dispositivos convencionais ou não convencionais.

A experiência com a utilização de outros tipos de simuladores possibilitou um melhor engajamento na tarefa proposta, visto que eles estariam habituados ao tipo de interação oferecida pelo dispositivo, assim como pela navegação no AV. Posteriormente, os participantes foram inquiridos a respeito das diferenças entre as interações proporcionadas pelo simulador de palpação e os sistemas de RV que eles já haviam manuseado.

A seguir, é feita uma breve descrição dos participantes:

- Voluntário 1: Possui 23 anos, apresenta formação superior em Sistemas de Informação e já utilizou simuladores de direção e jogos que utilizam dispositivos não convencionais. Este participante foi selecionado por apresentar uma breve experiência na área de RV, com foco na área médica.

- Voluntário 2: Possui 25 anos, apresenta formação superior em Ciência da Computação e já utilizou simuladores de direção e voo. Este participante foi selecionado por estar conduzindo um trabalho na área de serious games baseados em R.V. 
- Voluntário 3: Possui 25 anos, apresenta formação superior em Sistemas de Informação e utilizou jogos que adotam dispositivos não convencionais. Este participante foi selecionado por ter experiência no desenvolvimento de jogos para dispositivos móveis.

- Voluntário 4: Possui 27 anos, apresenta formação superior em Sistemas de Informação e experiência com simuladores de direção e jogos que utilizam dispositivos não convencionais. Este participante foi selecionado por estar trabalhando na área de jogos que empregam conceitos de RV.

Como é possível observar, todos os participantes envolvidos apresentavam conhecimentos dos principais conceitos de RV, visto que já haviam se envolvido em projetos da área. Tal conhecimento se mostrou muito pertinente para este trabalho, no sentido de avaliar a ferramenta do ponto de vista de um profissional que está apto a reconhecer a qualidade da interação oferecida por um simulador.

Com este experimento, esperava-se que os voluntários fossem capazes de identificar a presença de um nódulo ao percorrer a mama virtual com o dispositivo háptico, a partir do retorno de força propiciado pelo dispositivo. Evidentemente, por não constituírem o público-alvo, os indivíduos em questão não são capazes de proporem evoluções à ferramenta no concernente à simulação do exame em si, por não terem conhecimento das sensações que este tipo de exame traz. Ainda assim, a avaliação destes usuários foi pertinente neste estágio de implementação do simulador por indicarem que a utilização do dispositivo selecionado era adequada para a percepção de um objeto adicional no AV.

Antes da realização do experimento, os indivíduos foram submetidos a uma etapa de treinamento, durante a qual executaram a simulação do exame de palpação da mama com a estrutura do nódulo visível, conforme exibido na Figura 36. Sendo assim, além de sentir o retorno de força propiciado pelo toque do nódulo, eles puderam visualizá-lo. Esta etapa contribuiu para que eles conhecessem a estrutura do Ambiente Virtual, principalmente o formato dos objetos empregados.

Após esta familiarização com o uso do dispositivo háptico, foi explicado aos usuários que o objetivo da fase seguinte era realizar a palpação da mama virtual com a finalidade e encontrar o nódulo. O encontro do nódulo deveria ser identificado por um retorno de força mais intenso em relação àquele fornecido enquanto o usuário estava procurando tal estrutura. No momento da identificação deste retorno, o mesmo deveria ser comunicado 


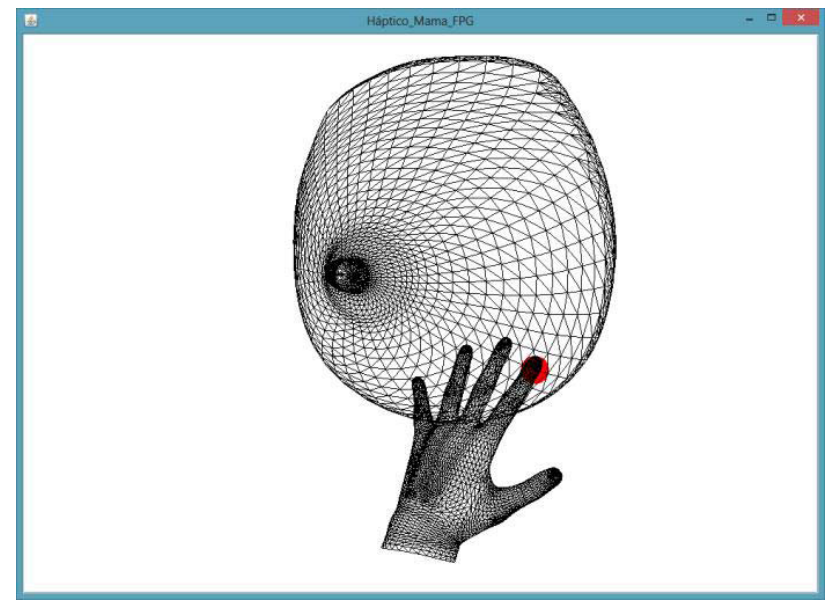

Figura 36 - Simulação do exame de palpação da mama com a estrutura do nódulo posicionada no canto inferior direito da mama.

imediatamente, para que o experimento fosse interrompido e o tempo total deste o início até a interrupção fosse aferido e posicionamento do dispositivo fosse registrado.

A estrutura que utiliza o recurso de estereoscopia também foi adotada no treinamento, conforme exibido na Figura 37. Os voluntários utilizaram o óculos na simulação com o recurso de estereoscopia e frisaram a sensação de imersão que essa estrutura oferece.

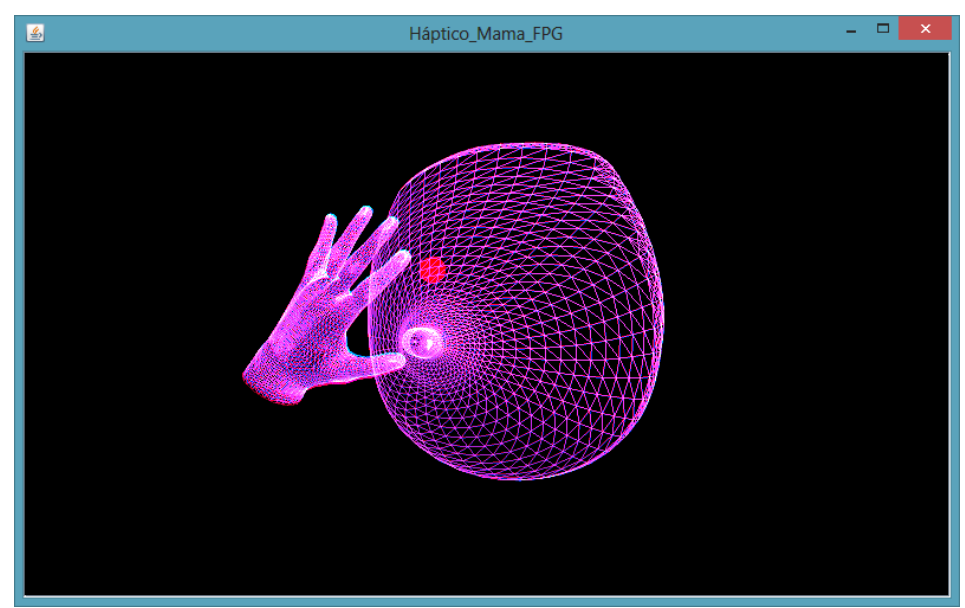

Figura 37 - Simulação do exame de palpação da mama utilizando o recurso de estereoscopia.

A avaliação consistiu na medição de tempo da ocorrência de uma colisão entre a mão virtual e o nódulo inserido na mama. O voluntário, com o auxílio do dispositivo háptico, fez a palpação do objeto virtual até que reconhecesse a sensação de um retorno háptico diferenciado, o que caracterizaria a descoberta de um nódulo, que se encontrava camuflado sob o objeto virtual, como exibido na Figura 35. 
Feito isto, foi realizada uma comparação entre o local no qual o usuário identificou o nódulo, (o local de posicionamento do braço do dispositivo háptico no momento que o voluntário reconheceu a força retornada) e o local em que a estrutura foi posicionada no modelo virtual. Desta forma, pretendia-se avaliar se o retorno háptico foi realmente preciso e ofereceu o auxílio necessário ao usuário na descoberta do nódulo mamário.

É importante ressaltar que, a fim de evitar qualquer tipo de aprendizado a respeito da localização do nódulo, a cada teste, o mesmo teve sua posição na mama gerada aleatoriamente. Foram realizadas três sessões de teste com cada voluntário, totalizando 12 testes. O tempo médio de descoberta do nódulo entre os participantes do experimento foi de 93 segundos, sendo que todos os indivíduos conseguiram identificar a posição do nódulo corretamente em todas as sessões.

Esta medida permite inferir que o retorno de força para o nódulo foi suficiente para que os voluntários percebessem a presença de uma estrutura mais rígida no AV. Em relação ao tempo médio para encontrar o nódulo, não é possível obter conclusões definitivas, dado que não foram encontrados estudos que façam menção a medições de tempo consideradas ideais para este tipo de exame. No geral, os comportamentos dos participantes foram muito parecidos, pois todos realizaram a simulação com uma análise minuciosa da mama, concentrando os esforços na tarefa de identificar o retorno de força diferenciado.

Em relação ao tempo de realização do experimento, nenhum participante se destacou sobre os demais, visto que todos obtiveram médias muito próximas. Entre a primeira e a última sessão de teste dos usuários, houve $25 \%$ de diminuição do tempo para encontrar o nódulo, pois, como dito anteriormente, eles foram se familiarizando com o ambiente e isto se refletiu no seu desempenho no experimento.

Inquirindo os participantes, todos destacaram a fácil interação com o dispositivo háptico e sua representação no ambiente virtual, que ajudaram muito no aspecto da imersão no AV. Contudo, também ressaltaram que o Phantom Omni talvez não fosse o dispositivo ideal para o treinamento deste tipo de exame, já que no exame de palpação o profissional de saúde utiliza todos os seus dedos para apalpar a mama, e este dispositivo não oferece tal precisão para cada dedo em particular.

Como mostrado na Figura 38, o braço mecânico acoplado à caneta stylus do dispositivo Phantom Omni dispõe apenas de um único ponto de contato. Este tipo de mecanismo é recomendado para interação em simuladores no qual haja a manipulação de um único objeto, como os procedimentos de punção utilizando agulhas. No caso da 
simulação da palpação, isto impossibilita que todos os dedos interajam diretamente com o objeto virtual, ou seja, os movimentos de cada dedo não são reconhecidos simultaneamente e a força não é retornada diretamente em cada um deles, o que pode não retratar fielmente a movimentação dos dedos do profissional de saúde durante o exame de palpação. Sendo assim, para este tipo de simulador, uma alternativa possível é fazer uma adaptação do dispositivo, como realizado em (JEON; CHOI; HARDERS, 2012). De qualquer forma, como o experimento com o simulador buscou diferenciar o retorno de força do nódulo em relação à mama e não a eficiência do dispositivo para este exame em específico, isto não invalidou os resultados obtidos em relação ao protótipo.

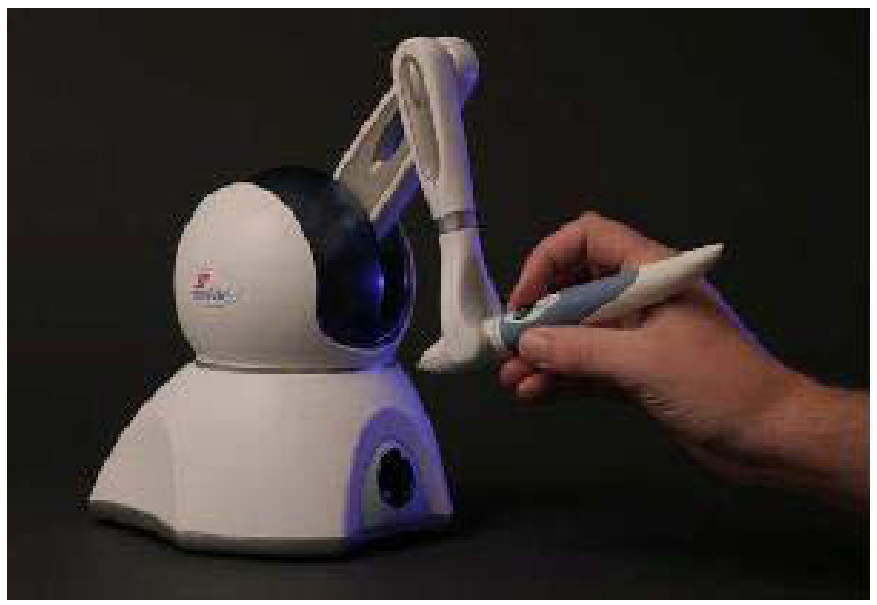

Figura 38 - Dispositivo háptico Phantom Omni

Fonte: (VRLAB, 2015)

Vale ressaltar ainda que o protótipo considerou um único objeto de interesse (nódulo), o qual foi suficiente como prova de conceito em relação ao retorno háptico. No entanto, no procedimento real é grande a variação nas estruturas nodulares. Como já apresentado anteriormente, uma das vantagens de se empregar um simulador virtual é a possibilidade de disponibilizar casos variados sem a necessidade de pacientes reais. Essa variedade de casos pode tornar o treinamento mais efetivo, mas os parâmetros de variação devem ser simulados com realismo a fim de que o treinamento contribua, de fato, para a aquisição da habilidade.

A simulação das estruturas citadas deve considerar múltiplas detecções de colisão, além de retornos sutis de força para simular as diferentes densidades dos nódulos. Além disso, a eficiência do treinamento exige a disponibilização de casos aleatórios e diversos, considerando-se os diversos parâmetros referentes ao nódulos que contribuem para que o médico componha um diagnóstico acertado. As características citadas imprimem uma 
considerável complexidade na construção do simulador, conforme pode ser percebido na avaliação da versão final da ferramenta, descrita a seguir.

\subsection{Avaliação da versão final do simulador}

A avaliação do simulador foi conduzida junto a uma médica mastologista, com experiência na área de Mastologia (clínica, diagnóstico e cirurgia) atuando principalmente nos seguintes temas: câncer de mama (rastreamento, detecção precoce e diagnóstico), mamografia (tela-filme e digital), diagnóstico em Mastologia (procedimentos invasivos), controle de qualidade e proteção radiológica em mamografia. A participante mencionou que já havia interagido com sistemas de RV, mas nunca com simuladores de palpação ou sistemas de RV voltados à medicina. Contudo, possuía experiência com o uso de modelos de silicone para treinamento de palpação da mama.

Antes da realização do experimento, a participante foi submetida a uma etapa de treinamento, durante a qual foi apresentada uma simulação de um exame com o nódulo visível. Assim, além de sentir o retorno de força propiciado pelo dispositivo quando o simulador identifica uma colisão da mão virtual com o nódulo, foi possível visualizar a estrutura nodular, a fim de possibilitar o reconhecimento e a diferenciação do retorno de força do propiciado pela colisão entre a mão virtual e o nódulo.

Para a condução da avaliação foram gerados alguns casos com variações das características do nódulo, o qual estava encoberto (não visível) pela estrutura virtual que representa a mama. Desta maneira, buscou-se verificar se os parâmetros implementados no simulador eram perceptíveis e representavam realisticamente as características encontradas nos nódulos mamários.

Ao todo, foram gerados nove casos de teste. Na seção 5.2.1 são apresentados os casos com variação na consistência dos nódulos virtuais. Nas demais subseções seguintes cada um dos parâmetros simulados é avaliado e discutido individualmente.

\subsubsection{Consistência do nódulo}

Nódulo fibroelástico: o primeiro caso apresentado à médica foi de um nódulo de consistência fibroelástica, cujo retorno háptico deveria se assemelhar a uma sensação cartilaginosa. Inicialmente, ela apresentou uma certa dificuldade em identificar o nódulo, 
tanto em razão do retorno háptico mais sutil deste tipo de nódulo quanto da dificuldade da profissional em se localizar dentro do AV. Alguns segundos depois, ela conseguiu encontrar o nódulo e, ao ser indagada a respeito da característica do nódulo, ela mencionou que a sensação aproximava-se da retornada por um nódulo fibroelástico, ainda que estivesse um pouco mais intensa do que no mundo real.

Nódulo pétreo: o caso seguinte, que apresentava um nódulo de consistência pétrea, mais rígida que o caso anterior, deveria ser mais perceptível em função do retorno háptico força de maior grandeza. E, de fato, aliando-se à adaptação da profissional com o uso da ferramenta, a identificação deste nódulo deu-se em um tempo menor. Novamente, ela respondeu corretamente o tipo do nódulo simulado, também frisando que o retorno do sistema estava ligeiramente mais intenso que o esperado.

Foram feitos alguns ajustes de calibragem das constantes (previamente apresentadas na subseção 4.2.4), e ela verificou que a sensação oferecida estava adequada para ambos os casos.

\subsubsection{Contorno do nódulo}

Nódulo redondo: neste caso, a sensação háptica a ser provida era muito semelhante à de uma pequena trepidação, ou seja, a médica deveria receber um retorno de força sutil no eixo vertical, como se o seu dedo estivesse deslizando sobre uma superfície redonda. A esta altura, no concernente à interação, a avaliadora já estava confortável com o uso do dispositivo, navegando pelo AV com facilidade. Logo, em pouco tempo fez a identificação do tipo do nódulo corretamente, reiterando que a sensação estava muito parecida com a real.

Nódulo espiculado: o retorno háptico deste tipo de nódulo deveria ser semelhante ao anterior, no sentido de que uma força vertical deveria ser percebida pela participante, aliada a retornos sutis intermitentes de força, representando as irregularidades da superfície deste tipo de nódulo. O retorno oferecido pelo simulador, no entanto, acabou tendo uma sensação mais vibratória, provavelmente em razão da ocorrência de mais de uma colisão com as irregularidades presentes na superfície do nódulo. A médica considerou que o retorno percebido não condiz com este tipo de nódulo. 


\subsubsection{Tamanho do nódulo}

Nódulo com diâmetro de $\mathbf{0 . 5} \mathbf{~} \mathbf{~ m}$ : conforme apresentado previamente e frisado pela médica, $0.5 \mathrm{~cm}$ é, em média, o menor tamanho de nódulo perceptível para os profissionais que já apresentam um nível de experiência avançado no exame de palpação e, portanto, já possuem um nível de percepção muito melhor do que os médicos que não foram submetidos a treinamento ou não estão habituados a realizar este exame com frequência. Sabendo disto, a profissional foi capaz de identificar o nódulo, levando em torno de 25 segundos a mais do que nos demais casos. Ela mencionou que considerou muito interessante e válido o recurso de poder configurar diferentes tamanhos de nódulos, em razão do intervalo bastante aberto entre os tamanhos que podem aparecer em casos reais.

Nódulo com diâmetro de $\mathbf{2} \mathbf{c m}$ : profissional identificou o nódulo corretamente. Mencionou que, apesar de ser um nódulo relativamente maior em relação ao caso anterior, ainda assim demanda um bom treinamento e experiência, pois de acordo com ela, este tamanho ainda está no intervalo de medidas que podem gerar dúvida no médico. Este intervalo varia de $0.5 \mathrm{~cm}$ a três centímetros.

\subsubsection{Localização do nódulo}

Quadrante superior externo - plano superficial: neste caso, o nódulo foi posicionado no plano superficial do quadrante superior externo. A profissional considerou interessante a possibilidade de posicionar o nódulo em um quadrante específico, assim como o retorno de força neste caso, que foi considerado adequado.

Quadrante inferior interno - plano profundo: neste caso, o nódulo foi posicionado no plano profundo do quadrante inferior. A participante avaliou que o avanço até o plano profundo não aparentou ser muito natural, assim como o retorno de força.

\subsubsection{Mobilidade do nódulo}

Neste caso, o nódulo foi configurado de forma a ser móvel, diferente dos outros casos, nos quais o foco foi a percepção de outras características. A profissional foi capaz de identificar o nódulo rapidamente, porém este teste gerou um pouco de dificuldade no sentido de entender o que estava acontecendo com o nódulo à medida em que ele era 
tocado. Alguns instantes depois, ela compreendeu que tratava-se de um nódulo móvel e, a partir de testes na mama transparente verificou a movimentação da estrutura virtual que o representa. A médica considerou o retorno de força para este nódulo satisfatório, contudo, sinalizou que a ausência das camadas e características das mamas prejudica ligeiramente esta simulação, em razão da influência delas neste contexto.

\subsubsection{Interfaces do simulador}

As interfaces do simulador e o processo de seleção de características e configuração dos casos para treinamento (apresentadas na subseção 4.2.9) foram disponibilizados para que a profissional pudesse gerar casos com os parâmetros que desejasse.

A profissional avaliou como simples e intuitivas as interfaces implementadas para a configuração dos casos. Além disto, considerou plausível o fluxo de configuração de casos a partir das interfaces do simulador, pois permite que um professor ou instrutor configure os casos com as características e parâmetros desejados e faça o acompanhamento do desempenho de um aluno durante o treinamento do procedimento.

\subsubsection{Considerações adicionais sobre a avaliação}

No geral, a profissional avaliou positivamente o simulador, no sentido de que ele está caminhando para ser uma excelente ferramenta de geração de diferentes casos para treinamento, ainda que alguns ajustes essenciais devam ser realizados a fim de proporcionar o realismo desejado. Em se tratando das características dos nódulos, já foi verificado um problema de mapeamento da sensação do nódulo espiculado para o simulador, em decorrência da vibração percebida durante o teste. Sendo assim, é necessário estudar novos algoritmos que possibilitem a configuração do retorno de força correto para este caso em particular.

Outro ponto destacado pela profissional diz respeito à mecânica natural do exame, o qual é normalmente realizado com as duas mãos. Sendo assim, ela considera que uma evolução natural e pertinente do simulador é acrescentar mais um dispositivo háptico ao sistema de simulação. Consequentemente, isto irá demandar um aprimoramento do simulador a fim de que ele consiga lidar com as interações proporcionadas por ambas 
as mãos, e, além disso, permita que as ações feitas por elas estejam relacionadas e proporcionem uma experiência completa de simulação.

A médica também mencionou que esta validação contemplou apenas os nódulos, e ainda que mapear as características deles seja um passo essencial, é imprescindível que as características das mamas também sejam levadas em consideração no contexto deste exame, até porque a própria mama pode apresentar indícios, até mesmo externos, de uma eventual patologia.

Outro comentário feito pela profissional diz respeito ao AV, que por meio dos objetos virtuais transmitiu um bom nível de realismo, mas também exigiu um certo esforço da parte dela a fim de que ela pudesse se situar dentro dele e ter uma boa noção do reflexo das suas ações dentro do AV. 


\section{Conclusões}

Este projeto de pesquisa teve por objetivo o estudo, avaliação e definição dos parâmetros e técnicas de retorno de força que simulem realisticamente um exame de palpação mamária, culminando no desenvolvimento de um simulador com retorno háptico para treinamento virtual do exame de palpação mamária.

A fim de alcançar o objetivo, foram realizados dois estudos: o primeiro buscou verificar quais as características mais relevantes dos nódulos mamários, que em um cenário de exame de palpação, permitissem a realização de um diagnóstico inicial de uma eventual patologia. O segundo estudo buscou selecionar e testar os principais parâmetros e técnicas de retorno de força, identificados a partir de uma revisão sistemática, que pudessem ser utilizados para a simulação de tais características dos nódulos.

De forma a validar os parâmetros e técnicas de retorno de força implementados, foram conduzidas avaliações com usuários leigos e uma profissional da medicina. A partir da avaliação do protótipo inicial do simulador com os usuários, verificou-se que o mesmo seria capaz de gerar aprendizado a partir da verificação de um retorno de força diferenciado, proporcionado por um objeto virtual que simula um nódulo, modelado dentro de um objeto virtual que simula uma mama.

A avaliação inicial com usuários leigos foi corroborada pela avaliação com uma médica mastologista, que, por meio da verificação do retorno de força de cada uma das características simuladas dos nódulos (contorno, consistência, mobilidade, tamanho e posição), validou as técnicas e equacionamentos desenvolvidos para obter realismo em relação ao retorno háptico. Além disso, também foram desenvolvidas e validadas interfaces que permitem a geração de casos a partir da seleção de determinadas características dos nódulos, permitindo a configuração de vários cenários de treinamento de exame de palpação para estudantes.

Outro ponto positivo da avaliação a ser destacado é que o dispositivo háptico, ainda que de baixo custo e com apenas um ponto de contato, foi capaz de fornecer uma simulação bastante real do procedimento quando adaptado. Um ponto negativo foi a simulação dos nódulos espiculados, que não foi realista, e precisa de melhorias.

Pode-se concluir que o trabalho atingiu o objetivo proposto, sendo que o simulador é capaz de fornecer casos com características variadas de nódulos, e o retorno háptico para simular tais características foi considerado adequado na maioria dos casos avalia- 
dos. Entretanto, algumas melhorias poderão ser incluídas no simulador. A atual versão apresenta limitação em relação à representação realista da mama, visto que não simula as diversas camadas que a formam e tampouco as características desta estrutura que podem ser indicativas de anormalidades. Adicionalmente, devem ser conduzidas avaliação mais extensivas com a adesão de um maior número de profissionais e estudantes da área de mastologia.

Sendo assim, a principal contribuição deste trabalho para as áreas de Ciência da Computação e Sistemas de Informação é a definição das técnicas de retorno de força e parâmetros hápticos que proporcionem o realismo necessário para a simulação de procedimentos com a mesma natureza do abordado no presente projeto.

A principal contribuição para a área de aplicação é a disponibilização de uma ferramenta que pode auxiliar no aperfeiçoamento das habilidades necessárias aos atuais e futuros profissionais de medicina para a realização do exame de palpação da mama. O uso da ferramenta disponibilizada pode contribuir para melhorar a confiança desses profissionais e, consequentemente, auxiliar na formação de diagnósticos mais assertivos.

O fato de ser uma ferramenta virtual, cujo dispositivo físico háptico empregado tem custo relativamente baixo, contribui simultaneamente para que o treinamento se torne mais acessível e disponível a um maior número de aprendizes. Contribuindo para alcançar uma maior quantidade de profissionais bem treinados, contribui-se também para diminuir os erros quando tais profissionais executarem o procedimento em pacientes reais. A adoção da ferramenta, portanto, pode oferecer impactos econômicos e sociais à área de detecção de doenças da mama.

\subsection{Trabalhos futuros}

A partir dos resultados obtidos, prevê-se a continuidade deste trabalho por meio das seguintes ações:

- Implementação de melhorias das técnicas de retorno de força em casos específicos: conforme discutido ao longo da seção 5.2, a implementação de algumas das características não obteve o resultado esperado ao longo da avaliação. Sendo assim, é necessário implementar e testar novas técnicas que permitam a simulação correta destas características; 
- Inclusão das camadas da mama e características da mama indicativas de câncer: a fim de oferecer uma experiência completa de simulação da palpação mamária, é necessário considerar toda a estrutura da mama, para que todas as características e peculiaridades das mamas sejam devidamente consideradas e a simulação seja o mais realista possível;

- Adaptação do simulador para considerar dois dispositivos hápticos, a fim de permitir a interação das duas mãos com o simulador: o procedimento correto do exame de palpação considera a utilização das duas mãos, de forma que a palpação seja o mais precisa possível. Desta maneira, para que o simulador possa oferecer o realismo ideal e esperado, deve-se adaptá-lo de forma a incluir mais um dispositivo háptico;

- Implementação de melhorias no AV do simulador, de forma a torná-lo mais intuitivo e responsivo às ações tomadas pelo usuário: um dos comentários no decorrer da avaliação da profissional mencionou a dificuldade em se localizar no AV, por isso, é necessário adaptar o AV para que ele seja mais intuitivo e responsivo ao usuário durante a simulação de um procedimento.

- Desenvolvimento de um módulo de avaliação do desempenho dos estudantes: uma vez que o simulador já gera casos variados, a interação do aprendiz com o simulador pode ser monitorada para tecer uma avaliação de desempenho do aprendizado, utilizando parâmetros obtidos automaticamente, como tempo, quantidade de erros e acertos, entre outros. Esses e outros elementos lúdicos podem fazer com que o simulador se torne uma ferramenta de ensino que motive o aprendiz na aquisição da habilidade.

- Adaptação dos parâmetros para palpação de outras regiões de interesse: a partir do estudo do retorno de força dos nódulos em outras regiões de interesse, como fígado e tireóide, assim como da inclusão dos respectivos objetos virtuais, pode-se adaptar o simulador a fim de que ele possa permitir o treinamento dos procedimentos de palpação utilizados nestas regiões.

\subsection{Artigos publicados e submetidos}

Os seguintes artigos foram publicados durante o desenvolvimento do presente projeto de pesquisa: 
- Systematically reviewing techniques and devices used in palpation simulation with haptic feedback (RIBEIRO; NUNES, 2014a);

- Breast palpation simulation with haptic feedback: prototype and initial results (RIBEIRO; NUNES, 2014b);

- Definition, implementation and validation of haptic feedback techniques for breast palpation examination (Workshop de Teses e Dissertações - Simpósio de Realidade virtual e Aumentada 2015)

O seguinte artigo foi submetido e aguarda resposta:

- Techniques and devices used in palpation simulation with haptic feedback - submetido para a revista ACM Computing Surveys 


\section{Referências $^{1}$}

ABOUD, E. et al. New alternative to animal models for surgical training. Alternatives to laboratory animals: ATLA, v. 32 Suppl 1B, p. 501-507, June 2004. ISSN 0261-1929. Disponível em: <http://europepmc.org/abstract/MED/23581125>. Citado na página 29.

ABSOLUTE Technologies. 2015. http://www.abs-tech.com/. Acessado em: 02 jan. 2015. Citado na página 34.

ACM Digital Library. 2015. http://dl .acm.org/. Acessado em: 09 jan. 2015. Citado na página 36.

ADAMS, R.; HANNAFORD, B. Stable haptic interaction with virtual environments. Robotics and Automation, IEEE Transactions on, v. 15, n. 3, p. 465-474, Jun 1999. ISSN 1042-296X. Citado na página 30.

ALHALABI, M. et al. Medical training simulation for palpation of subsurface tumor using hiro. In: Eurohaptics Conference, 2005 and Symposium on Haptic Interfaces for Virtual Environment and Teleoperator Systems, 2005. World Haptics 2005. First Joint. [S.l.: s.n.], 2005. p. 623-624. Citado 3 vezes nas páginas 43, 49 e 116.

ALMEIDA, I. de S. Simulador de realidade virtual para o treinamento de biópsia por agulha de nódulos da glândula tireóide. Tese (Doutorado) - Universidade de São Paulo, 2007. Citado na página 62.

ALMEIDA, O. J.; JORGE, J. d. P. N.; CECATTI, J. G. Desempenho do exame clínico das mamas no diagnóstico diferencial de nódulos mamários. Revista de Ciências Médicas, v. 7, n. 2, 2012. Citado 2 vezes nas páginas 24 e 26.

ANJOS, A. M. dos; NUNES, F. d. L. dos S.; TORI, R. Avaliação de habilidades sensório-motoras em ambientes de realidade virtual para treinamento médico: uma revisão sistemática. Journal of Health Informatics, v. 4, n. 1, 2012. Citado na página 28.

AZEVEDO, C. M. et al. Análise computacional da textura de tumores de mama em imagens por ultrassom de pacientes submetidas a cirurgia conservadora. Radiol Bras, SciELO Brasil, v. 42, p. 363-9, 2009. Citado na página 25.

BAILLIE, S. et al. Validation of a bovine rectal palpation simulator for training veterinary students. Studies in health technology and informatics, IOS Press, v. 111, p. 33-36, 2005. Citado 3 vezes nas páginas 46, 54 e 114 .

BAILLIE, S. et al. Evaluating an automated haptic simulator designed for veterinary students to learn bovine rectal palpation. Simulation in healthcare: journal of the Society for Simulation in Healthcare, v. 5, n. 5, p. 261-266, 2010. Citado 3 vezes nas páginas 47, 55 e 109.

BAILLIE, S. et al. Integrating a bovine rectal palpation simulator into an undergraduate veterinary curriculum. Journal of veterinary medical education, v. 32, n. 1, p. 79, 2005. Citado 2 vezes nas páginas 47 e 114.

1 De acordo com a Associação Brasileira de Normas Técnicas. NBR 6023. 
BAJAJ, K. et al. Repeated palpatory training of medical students on the virtual haptic back. Studies in health technology and informatics, v. 132, p. 8, 2008. Citado na página 113.

BARILLI, E. C. V. C.; EBECKEN, N. F. F.; CUNHA, G. G. The technology of virtual reality resource for formation in public health in the distance: an application for the learning of anthropometric procedures. Ciência \& Saúde Coletiva, SciELO Brasil, v. 16, p. 1247-1256, 2011. Citado na página 31.

BASAFA, E.; SEFATI, S.; OKAMURA, A. Assessing the quality of force feedback in soft tissue simulation. In: Engineering in Medicine and Biology Society, EMBC, 2011 Annual International Conference of the IEEE. [S.l.: s.n.], 2011. p. 3451-3454. ISSN 1557-170X. Citado 5 vezes nas páginas 48, 50, 52, 56 e 108.

BAñOS, R. M. et al. Presence and emotions in virtual environments: the influence of stereoscopy. Cyberpsychology \& behavior : the impact of the Internet, multimedia and virtual reality on behavior and society, v. 11, n. 1, p. 1-8, February 2008. ISSN 1094-9313. Disponível em: <http://dx.doi.org/10.1089/cpb.2007.9936>. Citado na página 33.

BIBLIOTECA Digital de Teses e Dissertações da USP. 2015. http://www . teses . usp . br/. Acessado em: 09 jan. 2015. Citado na página 37.

BIOLCHINI, J. C. de A. et al. Scientific research ontology to support systematic review in software engineering. Adv. Eng. Inform., Elsevier Science Publishers B. V., Amsterdam, The Netherlands, The Netherlands, v. 21, n. 2, p. 133-151, abr. 2007. ISSN 1474-0346. Disponível em: <http://dx.doi.org/10.1016/j.aei.2006.11.006>. Citado 3 vezes nas páginas 35, 36 e 38 .

BOTEGA, L. C. et al. Implementação de estereoscopia de baixo custo para aplicações em ferramentas de realidade virtual para treinamento médico. 2005. Citado na página 33.

BRYAN, T.; SNYDER, E. The clinical breast exam: a skill that should not be abandoned. Journal of general internal medicine, v. 28, n. 5, p. 719-722, May 2013. ISSN 0884-8734. Disponível em: <http://europepmc.org/articles/PMC3631083>. Citado 2 vezes nas páginas 22 e 23.

BURDEA, G.; COIFFET, P. Virtual reality technology. Presence, v. 12, n. 6, p. 663-664, Dec 2003. ISSN 1054-7460. Citado na página 26.

BURDEA, G. et al. Virtual reality-based training for the diagnosis of prostate cancer. Biomedical Engineering, IEEE Transactions on, v. 46, n. 10, p. 1253-1260, Oct 1999. ISSN 0018-9294. Citado na página 114.

BURDEA, G. C. Force and touch feedback for virtual reality. [S.l.]: Wiley New York, 1996. Citado 2 vezes nas páginas 29 e 30.

CHOI, K.-S.; SUN, H.; HENG, P.-A. Interactive deformation of soft tissues with haptic feedback for medical learning. Information Technology in Biomedicine, IEEE Transactions on, v. 7, n. 4, p. 358-363, Dec 2003. ISSN 1089-7771. Citado 4 vezes nas páginas 48, 49, 51 e 111. 
CHOI, K. S. et al. A scalable force propagation approach for web-based deformable simulation of soft tissues. In: Proceedings of the Seventh International Conference on 3D Web Technology. New York, NY, USA: ACM, 2002. (Web3D '02), p. 185-193. ISBN 1-58113-468-1. Disponível em: <http://doi.acm.org/10.1145/504502.504532>. Citado 2 vezes nas páginas 28 e 63.

CIVIAM. 2015. <http://www.civiam.com.br/civiam/index.php/ habilidades-skill-trainers/medicina-simuladores/exame-de-mamas/ simulador-avancado-de-mamas-para-treinamento-clinico-e-palpacao.html. Acessado em: 03 jan. 2015. Citado na página 21.

COLES, T. et al. Integrating haptics with augmented reality in a femoral palpation and needle insertion training simulation. Haptics, IEEE Transactions on, v. 4, n. 3, p. 199-209, May 2011. ISSN 1939-1412. Citado na página 111.

COLES, T.; MEGLAN, D.; JOHN, N. The role of haptics in medical training simulators: A survey of the state of the art. Haptics, IEEE Transactions on, v. 4, n. 1, p. 51-66, Jan 2011. ISSN 1939-1412. Citado 11 vezes nas páginas 16, 20, 28, 29, 43, 44, 52, 53, 54, 68 e 114 .

D'AULIGNAC, D. et al. Towards a realistic echographic simulator. Medical image analysis, Elsevier, v. 10, n. 1, p. 71-81, 2006. Citado na página 114.

DINSMORE, M. et al. Virtual reality training simulation for palpation of subsurface tumors. In: Virtual Reality Annual International Symposium, 1997., IEEE 1997. [S.l.: s.n.], 1997. p. 54-60. ISSN 1087-8270. Citado 2 vezes nas páginas 44 e 116.

EVERETT, K. et al. A virtual reality interface to provide point interaction and constriction to the finger. In: Systems and Information Engineering Design Symposium, 2009. SIEDS '09. [S.l.: s.n.], 2009. p. 203-207. Citado 4 vezes nas páginas 47, 52, 55 e 108.

FIFTH Dimension Technologies. 2015. http://www.5dt.com/. Acessado em: 02 jan. 2015. Citado 2 vezes nas páginas 32 e 34.

FRISOLI, A.; BORELLI, L.; BERGAMASCO, M. Modeling biologic soft tissues for haptic feedback with an hybrid multiresolution method. Studies in health technology and informatics, p. 111, 2005. Citado 4 vezes nas páginas 48, 49, 55 e 112.

GALLAGER, H. S.; MARTIN, J. E. Early phases in the development of breast cancer. Cancer, Wiley Subscription Services, Inc., A Wiley Company, v. 24, n. 6, p. 1170-1178, 1969. ISSN 1097-0142. Disponível em: <http://dx.doi.org/10.1002/10970142(196912)24:6<1170::AID-CNCR2820240615>3.0.CO;2-6>. Citado na página 26.

GEOMAGIC. 2015. <http://www.geomagic.com. Acessado em: 03 jan. 2015. Citado 4 vezes nas páginas $31,32,51$ e 52 .

GERLING, G. J.; THOMAS, G. W. Augmented, pulsating tactile feedback facilitates simulator training of clinical breast examinations. Human factors, v. 47, n. 3, p. 670-681, 2005. ISSN 0018-7208. Disponível em: <http://europepmc.org/abstract/MED/16435705>. Citado na página 18. 
GERLING, G. J. et al. Effectiveness of a dynamic breast examination training model to improve clinical breast examination (cbe) skills. Cancer detection and prevention, v. 27, n. 6, p. 451-456, 2003. ISSN 0361-090X. Disponível em: <http://dx.doi.org/10.1016/j.cdp.2003.09.008>. Citado na página 17.

GLADSTONE, H. B. et al. Virtual reality for dermatologic surgery: virtually a reality in the 21st century. Journal of the American Academy of Dermatology, Elsevier, v. 42, n. 1, p. 106-112, 2000. Citado na página 114.

GOMOLL, A. H. et al. Surgical experience correlates with performance on a virtual reality simulator for shoulder arthroscopy. The American journal of sports medicine, v. 35, n. 6, p. 883-888, June 2007. ISSN 0363-5465. Disponível em: <http://dx.doi.org/10.1177/0363546506296521>. Citado na página 29.

GOOGLE Acadêmico. 2015. http://scholar.google.com.br. Acessado em: 09 jan. 2015. Citado na página 36.

GRECHENIG, W. et al. The graz learning and training model for arthroscopic surgery. Surgical and radiologic anatomy : SRA, v. 21, n. 5, p. 347-350, 1999. ISSN 0930-1038. Disponível em: <http://dx.doi.org/10.1007/BF01631337>. Citado 2 vezes nas páginas 29 e 54.

GREENLEAF, W. Medical applications of virtual reality. Overview February, 2004. Citado na página 27.

HAMAMOTO, K. Investigation on virtual palpation system using ultrasonic elasticity imaging. In: Engineering in Medicine and Biology Society, 2006. EMBS '06. 28th Annual International Conference of the IEEE. [S.l.: s.n.], 2006. p. 4873-4876. ISSN 1557-170X. Citado na página 112.

HEGG, R. Câncer de mama. Rev. Bras. Med, v. 57, n. 5, p. 463-473, 2000. Citado na página 26.

HOSSEINI, M. et al. Detection of tumours using a computational tactile sensing approach. The International Journal of Medical Robotics and Computer Assisted Surgery, Wiley Online Library, v. 2, n. 4, p. 333-340, 2006. Citado 3 vezes nas páginas 43, 50 e 109.

HOSSEINI, S. M. et al. A medical tactile sensing instrument for detecting embedded objects, with specific application for breast examination. The international journal of medical robotics + computer assisted surgery : MRCAS, v. 6, n. 1, p. 73-82, March 2010. ISSN 1478-5951. Disponível em: <http://dx.doi.org/10.1002/rcs.291>. Citado 3 vezes nas páginas 43, 50 e 108.

HOWELL, J. N. et al. Palpatory diagnosis training on the virtual haptic back: Performance improvement and user evaluations. JAOA: Journal of the American Osteopathic Association, Am Osteopathic Assoc, v. 108, n. 1, p. 29-36, 2008. Citado 2 vezes nas páginas 45 e 112.

HOWELL, J. N. et al. The virtual haptic back: a simulation for training in palpatory diagnosis. BMC medical education, BioMed Central Ltd, v. 8, n. 1, p. 14, 2008. Citado 2 vezes nas páginas 45 e 114. 
IEEE Xplore Digital Library. 2015. http://ieeexplore.ieee.org/. Acessado em: 09 jan. 2015. Citado na página 36.

INCA. INCA - Instituto Nacional de Câncer/Ministério da Saúde. Falando sobre câncer de mama. 2015. <http://www. saude.pb.gov.br/web_data/saude/cancer/aula11.pdf/. Acessado em: 03 out. 2015. Citado na página 24.

JAUNG, R.; COOK, P.; BLYTH, P. A comparison of embalming fluids for use in surgical workshops. Clinical Anatomy, Wiley Subscription Services, Inc., A Wiley Company, v. 24, n. 2, p. 155-161, 2011. ISSN 1098-2353. Disponível em: $<$ http://dx.doi.org/10.1002/ca.21118>. Citado na página 29.

JAVA3D. Java3D. 2015. <http://www.oracle.com/technetwork/articles/javase/ index-jsp-138252.html. Acessado em: 03 out. 2015. Citado na página 60.

JEON, S.; CHOI, S.; HARDERS, M. Rendering virtual tumors in real tissue mock-ups using haptic augmented reality. Haptics, IEEE Transactions on, v. 5, n. 1, p. 77-84, Jan 2012. ISSN 1939-1412. Citado 4 vezes nas páginas 43, 72, 84 e 113.

JEON, S. et al. Haptic simulation of breast cancer palpation: A case study of haptic augmented reality. In: Mixed and Augmented Reality (ISMAR), 2010 9th IEEE International Symposium on. [S.1.: s.n.], 2010. p. 237-238. Citado 4 vezes nas páginas 43, 61, 72 e 110.

KANN, P.; LANE, D. Breast cancer screening knowledge and skills of students upon entering and exiting a medical school. Academic medicine : journal of the Association of American Medical Colleges, v. 73, n. 8, p. 904-906, August 1998. ISSN 1040-2446. Disponível em: <http://dx.doi.org/10.1097/00001888-199808000-00017>. Citado na página 16.

KARADOGAN, E. et al. A stiffness discrimination experiment including analysis of palpation forces and velocities. Simulation in Healthcare, LWW, v. 5, n. 5, p. 279-288, 2010. Citado 3 vezes nas páginas 52, 55 e 108.

KESNER, S.; HOWE, R. Discriminating tissue stiffness with a haptic catheter: Feeling the inside of the beating heart. In: World Haptics Conference (WHC), 2011 IEEE. [S.l.: s.n.], 2011. p. 13-18. Citado 2 vezes nas páginas 45 e 109.

KHALED, W. et al. Palpation imaging using a haptic system for virtual reality applications in medicine. Studies in health technology and informatics, v. 98, p. 147-153, 2003. Citado 2 vezes nas páginas 43 e 112.

KIM, J. et al. Inclusion detection with haptic-palpation system for medical telediagnosis. In: Engineering in Medicine and Biology Society, 2009. EMBC 2009. Annual International Conference of the IEEE. [S.l.: s.n.], 2009. p. 4595-4598. ISSN 1557-170X. Citado 2 vezes nas páginas 43 e 111.

KIM, Y. et al. Six-degree-of-freedom haptic display using localized contact computations. In: Haptic Interfaces for Virtual Environment and Teleoperator Systems, 2002. HAPTICS 2002. Proceedings. 10th Symposium on. [S.l.: s.n.], 2002. p. 209-216. Citado na página 31. 
KINNISON, T. et al. Teaching bovine abdominal anatomy: Use of a haptic simulator. Anatomical sciences education, Wiley Online Library, v. 2, n. 6, p. 280-285, 2009. Citado na página 113.

KITCHENHAM, B. Procedures for performing systematic reviews. Keele, UK, Keele University, v. 33, p. 2004, 2004. Citado 2 vezes nas páginas 35 e 38.

KORMOS, K. et al. [new possibilities in practical education of surgery]. Magyar sebeszet, v. 66, n. 5, p. 256-262, 2013. Citado na página 28.

KOTRANZA, A.; LIND, D.; LOK, B. Real-time evaluation and visualization of learner performance in a mixed-reality environment for clinical breast examination. Visualization and Computer Graphics, IEEE Transactions on, v. 18, n. 7, p. 1101-1114, July 2012. ISSN 1077-2626. Citado na página 16.

KURODA, Y. et al. Organ exclusion simulation with multi-finger haptic interaction for open surgery simulator. Studies in health technology and informatics, v. 125, p. 244, 2007. Citado na página 115.

KURODA, Y. et al. Interaction model between elastic objects for haptic feedback considering collisions of soft tissue. Computer Methods and Programs in Biomedicine, v. 80 , n. 3, p. 216 - 224, 2005. ISSN 0169-2607. Disponível em: <http://www.sciencedirect.com/science/article/pii/S0169260705001902>. Citado na página 111.

KURODA, Y. et al. Haptic rate for surgical manipulations with fingers and instruments. Studies in health technology and informatics, v. 132, p. 230-232, 2007. Citado na página 115.

LAMBDEN, S.; MARTIN, B. The use of computers for perioperative simulation in anesthesia, critical care, and pain medicine. Anesthesiology clinics, v. 29, n. 3, p. 521-531, September 2011. ISSN 1932-2275. Disponível em: <http://dx.doi.org/10.1016/j.anclin.2011.05.006>. Citado na página 28.

LANGRANA, N. et al. Human performance using virtual reality tumor palpation simulation. Computers \& Graphics, Elsevier, v. 21, n. 4, p. 451-458, 1997. Citado 2 vezes nas páginas 44 e 115.

LANGRANA, N. A. et al. Dynamic force feedback in a virtual knee palpation. Artificial Intelligence in Medicine, v. 6, n. 4, p. 321 - 333, 1994. ISSN 0933-3657. Virtual Reality in Medicine. Disponível em: <http://www.sciencedirect.com/science/article/pii/0933365794900361>. Citado 2 vezes nas páginas 41 e 109.

LEE, O. et al. Prototype tactile feedback system for examination by skin touch. Skin research and technology: official journal of International Society for Bioengineering and the Skin (ISBS)[and] International Society for Digital Imaging of Skin (ISDIS)[and] International Society for Skin Imaging (ISSI), 2013. Citado 3 vezes nas páginas 48, 54 e 112.

LIBERATI, A. et al. The prisma statement for reporting systematic reviews and meta-analyses of studies that evaluate health care interventions: explanation and elaboration. Annals of internal medicine, Am Coll Physicians, v. 151, n. 4, p. W-65, 2009. Citado na página 37. 
LUBOZ, V. et al. Imagine seldinger: First simulator for seldinger technique and angiography training. Computer Methods and Programs in Biomedicine, v. 111, n. 2, p. 419 - 434, 2013. ISSN 0169-2607. Disponível em: <http://www.sciencedirect.com/science/article/pii/S0169260713001715>. Citado 6 vezes nas páginas 44, 45, 49, 51, 55 e 111.

MACHADO, L. d. S. A Realidade Virtual no Modelamento e Simulação de Procedimentos Invasivos em Oncologia Pediátrica: Um Estudo de Caso no Transplante de Medula Óssea. 2003. 130 f. Tese (Doutorado) — Tese (Doutorado)-Departamento de Engenharia, Escola Politécnica da Universidade de São Paulo, São Paulo-SP, 2003. Citado 2 vezes nas páginas 27 e 33 .

MACHADO, L. d. S. et al. Serious games baseados em realidade virtual para educação médica; serious games based on virtual reality in medical education. Rev. bras. educ. méd, v. 35, n. 2, p. 254-262, 2011. Citado na página 28.

MACHADO, L. dos S.; MORAES, R. M. de. Vr-based simulation for the learning of gynaecological examination. In: Advances in Artificial Reality and Tele-Existence. [S.l.]: Springer, 2006. p. 97-104. Citado 3 vezes nas páginas 47, 52 e 115.

MADAN, A. K. et al. Education of medical students in clinical breast examination during surgical clerkship. The American Journal of Surgery, v. 184, n. 6, p. 637 - 640, 2002. ISSN 0002-9610. Disponível em: <http://www.sciencedirect.com/science/article/pii/S0002961002010942>. Citado na página 16.

MAHVASH, M. et al. Force-feedback surgical teleoperator: Controller design and palpation experiments. In: Haptic interfaces for virtual environment and teleoperator systems, 2008. haptics 2008. symposium on. [S.l.: s.n.], 2008. p. 465-471. Citado na página 110.

MCCREERY, G. et al. Evaluation of force feedback requirements for minimally invasive lung tumour localization. In: Intelligent Robots and Systems, 2007. IROS 2007. IEEE/RSJ International Conference on. [S.l.: s.n.], 2007. p. 883-888. Citado 2 vezes nas páginas 43 e 109.

MCDONALD, S.; SASLOW, D.; ALCIATI, M. H. Performance and reporting of clinical breast examination: a review of the literature. CA: a cancer journal for clinicians, v. 54, n. 6, p. 345-361, 2004. ISSN 0007-9235. Disponível em: <http://caonline.amcancersoc.org/cgi/reprint/54/6/345.pdf $>$. Citado 3 vezes nas páginas 16, 21 e 22 .

MCLAUGHLIN, M. et al. Haptic simulator for training in clinical breast examination. Annenberg School for Communication, Annenberg, 2003. Citado 2 vezes nas páginas 43 e 116.

MOKHTARI, M. et al. Virtual environment and sensori-motor activities: visualization. UNION Agency-Science Press, 2004. Citado na página 34.

MONTERO, E. F. S.; ZANCHET, D. J. Realidade virtual e a medicina. Acta Cirúrgica Brasileira, SciELO Brasil, v. 18, n. 5, p. 489-490, 2003. Citado na página 16.

MORAES, R. M. D.; MACHADO, L. dos S.; SOUZA, A. C. M. de. Virtwall: A concept of low-cost virtual wall for immersion in virtual reality. Citeseer, 2003. Citado na página 27. 
NAKAGAWA, Y.; OGURO, R. Haptic force simulation for cardiac muscle palpation training system. In: ICCAS-SICE, 2009. [S.1.: s.n.], 2009. p. 3781-3787. Citado 2 vezes nas páginas 42 e 110.

NAZÁRIO, A. C. P.; REGO, M. F. Nódulos benignos da mama: uma revisão dos diagnósticos diferenciais e conduta. Rev Bras Ginecol Obstet, SciELO Brasil, v. 29, n. 4, p. 211-9, 2007. Citado na página 25.

NEIDER, J.; DAVIS, T.; WOO, M. OpenGL programming guide. [S.l.]: Addison-Wesley Reading, MA, 1993. Citado na página 65.

NETTO, A. V.; MACHADO, L. d. S.; OLIVEIRA, M. C. F. d. Realidade virtual: fundamentos e aplicações. [S.l.]: Visual Books, 2002. Citado na página 32.

NOVINT Falcon. 2015. http://www.novint.com/index.php/novintfalcon. Acessado em: 02 jan. 2015. Citado na página 53.

NUNES, E. P. d. S. Um método para avaliar a aquisição de conhecimento em ambientes virtuais de aprendizagem tridimensionais interativos. Tese (Doutorado) - Universidade de São Paulo, 2014. Citado na página 27.

NUNES, F.; MACHADO, L.; MORAES, R. Evolution of virtual and augmented reality in health: A reflection from 15 years of svr. In: Virtual and Augmented Reality (SVR), 2014 XVI Symposium on. [S.l.: s.n.], 2014. p. 220-229. Citado na página 57.

NUNES, F. L. S.; COSTA, R. M. E. M. The virtual reality challenges in the health care area: A panoramic view. In: Proceedings of the 2008 ACM Symposium on Applied Computing. New York, NY, USA: ACM, 2008. (SAC '08), p. 1312-1316. ISBN 978-1-59593-753-7. Disponível em: <http://doi.acm.org/10.1145/1363686.1363993>. Citado na página 27.

NUNES, F. L. S. et al. Realidade virtual para saúde no brasil: conceitos, desafios e oportunidades. Rev. Bras. Eng. Biom, v. 27, n. 4, p. 243-258, 2011. Citado 2 vezes nas páginas 16 e 28.

OAKLEY, I. et al. Putting the feel in \&rsquo;look and feel\&lsquo;. In: Proceedings of the SIGCHI Conference on Human Factors in Computing Systems. New York, NY, USA: ACM, 2000. (CHI '00), p. 415-422. ISBN 1-58113-216-6. Disponível em: $<$ http://doi.acm.org/10.1145/332040.332467>. Citado na página 31.

OKAMURA, A. et al. Haptics in medicine and clinical skill acquisition. Haptics, IEEE Transactions on, v. 4, n. 3, p. 153-154, May 2011. ISSN 1939-1412. Citado na página 17.

OLIVEIRA, A. C. T. M. G.; NUNES, F. L. S. Building a open source framework for virtual medical training. Journal of digital imaging, v. 23, n. 6, p. 706-720, December 2010. ISSN 0897-1889. Disponível em: <http://europepmc.org/articles/PMC2978884>. Citado 5 vezes nas páginas 16, 59, 62, 63 e 66 .

OLIVEIRA, A. de; NUNES, F.; BEZERRA, A. Geração de ferramentas para treinamento de biópsia utilizando um framework de rv. 2007. Citado 2 vezes nas páginas 27 e 60 .

OTTERMO, M. V. et al. The role of tactile feedback in laparoscopic surgery. Surgical Laparoscopy Endoscopy \& Percutaneous Techniques, LWW, v. 16, n. 6, p. 390-400, 2006. Citado na página 114. 
PARKES, R.; FORREST, N.; BAILLIE, S. A mixed reality simulator for feline abdominal palpation training in veterinary medicine. Studies in health technology and informatics, v. 142, p. 244-246, 2009. ISSN 0926-9630. Disponível em: <http:-

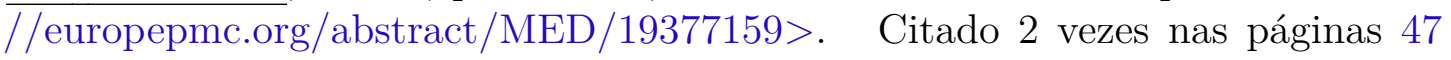
e 108.

PERRI, M. et al. Initial evaluation of a tactile/kinesthetic force feedback system for minimally invasive tumor localization. Mechatronics, IEEE/ASME Transactions on, v. 15, n. 6, p. 925-931, Dec 2010. ISSN 1083-4435. Citado na página 111.

PETRIE, M.; THOMAS, G. Mechanical properties of the haptic signals indicative of a breast cancer tumor. In: Systems, Man and Cybernetics, 2007. ISIC. IEEE International Conference on. [S.l.: s.n.], 2007. p. 2233-2238. Citado 2 vezes nas páginas 16 e 21.

PUBMED. 2015. http://www.ncbi.nlm.nih.gov/pubmed. Acessado em: 09 jan. 2015. Citado na página 36.

PUGH, C. M.; SALUD, L. H. Fear of missing a lesion: use of simulated breast models to decrease student anxiety when learning clinical breast examinations. The American Journal of Surgery, v. 193, n. 6, p. 766 - 770, 2007. ISSN 0002-9610. Disponível em: <http://www.sciencedirect.com/science/article/pii/S0002961007001535>. Citado na página 16.

RAHBAR, G. et al. Benign versus malignant solid breast masses: Us differentiation. Radiology, v. 213, n. 3, p. 889-894, 1999. PMID: 10580971. Disponível em: <http://dx.doi.org/10.1148/radiology.213.3.r99dc20889>. Citado na página 24.

RAPOSO, A. B. et al. Visão estereoscópica, realidade virtual, realidade aumentada e colaboração. 2004. Citado na página 34.

RIBEIRO, M.; NUNES, F. Systematically reviewing techniques and devices used in palpation simulation with haptic feedback. In: Virtual and Augmented Reality (SVR), 2014 XVI Symposium on. [S.l.: s.n.], 2014. p. 258-267. Citado na página 93.

RIBEIRO, M. D. L.; NUNES, F. Breast palpation simulation with haptic feedback: Prototype and initial results. In: Virtual and Augmented Reality (SVR), 2014 XVI Symposium on. [S.l.: s.n.], 2014. p. 268-276. Citado na página 93.

RIEDER, R. et al. Uma avaliação do uso de estímulos táteis em um ambiente virtual.

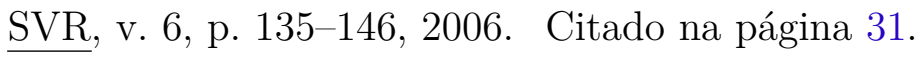

ROBLES-DE-LA-TORRE, G. The importance of the sense of touch in virtual and real environments. MultiMedia, IEEE, v. 13, n. 3, p. 24-30, July 2006. ISSN 1070-986X. Citado na página 57.

ROKE, C. et al. The effects of laterotactile information on lump localization through a teletaction system. In: World Haptics Conference (WHC), 2013. [S.l.: s.n.], 2013. p. 365-370. Citado 2 vezes nas páginas 53 e 113.

SAMET, H. Neighbor finding in images represented by octrees. Computer Vision, Graphics, and Image Processing, Elsevier, v. 46, n. 3, p. 367-386, 1989. Citado na página 62. 
SATAVA, R. M. Medical applications of virtual reality. J. Med. Syst., Plenum Press, New York, NY, USA, v. 19, n. 3, p. 275-280, jun. 1995. ISSN 0148-5598. Disponível em: <http://dx.doi.org/10.1007/BF02257178>. Citado na página 112.

SAÚDE, C. Adenopatia axilar. 2015. <http://saude.ccm.net/faq/ 17-adenopatia-axilar/. Citado na página 25.

SCHUBART, J. R. et al. Use of breast simulators compared with standardized patients in teaching the clinical breast examination to medical students. Journal of Surgical Education, v. 69, n. 3, p. 416 - 422, 2012. ISSN 1931-7204. Disponível em: <http://www.sciencedirect.com/science/article/pii/S1931720411002959>. Citado 3 vezes nas páginas 18, 23 e 24 .

SILVA, T. S. d.; OLIVEIRA, C. F. d. Doença benigna da mama. 2010. Citado 2 vezes nas páginas 25 e 26.

SISCOUTTO, R. A. et al. Estereoscopia. Realidade Virtual: Conceitos e Tendências". Livro do Pré-Simpósio, 2004. Citado na página 33.

STALFORS, J. et al. Haptic palpation of head and neck cancer patients-implication for education and telemedicine. Studies in health technology and informatics, v. 81, p. 471, 2001. Citado na página 110.

STEFANIDIS, D. et al. Cadavers versus pigs: which are better for procedural training of surgery residents outside the or? Surgery, v. 154, n. 1, p. 34-37, July 2013. ISSN 0039-6060. Disponível em: <http://dx.doi.org/10.1016/j.surg.2013.05.001>. Citado na página 29.

SUZUKI, N. et al. Virtual surgery system using deformable organ models and force feedback systems with three fingers. In: SPRINGER-VERLAG. Proceedings of the First International Conference on Medical Image Computing and Computer-Assisted Intervention. [S.l.], 1998. p. 397-403. Citado 2 vezes nas páginas 42 e 115.

TALASAZ, A.; PATEL, R. Remote palpation to localize tumors in robot-assisted minimally invasive approach. In: Robotics and Automation (ICRA), 2012 IEEE International Conference on. [S.l.: s.n.], 2012. p. 3719-3724. ISSN 1050-4729. Citado 3 vezes nas páginas 41, 54 e 113.

TANI, G. et al. Aprendizagem motora: tendências, perspectivas e aplicações. Rev. paul. educ. fís, v. 18, n. esp, p. 55-72, 2004. Citado na página 17.

TOKUYASU, T. et al. Development of training system for left ventricular plastic surgery. In: Biomedical Engineering, 2003. IEEE EMBS Asian-Pacific Conference on. [S.l.: s.n.], 2003. p. 60-61. Citado na página 116.

TOKUYASU, T. et al. Development of an inheritance assist system for experiencing operation skills by using a haptic function of phantom. Artif. Life Robot., Springer-Verlag New York, Inc., Secaucus, NJ, USA, v. 15, n. 2, p. 195-198, set. 2010. ISSN 1433-5298. Disponível em: <http://dx.doi.org/10.1007/s10015-010-0789-4>. Citado 4 vezes nas páginas 42, 51, 52 e 109.

TORRIERI. 2015. <http://fisioterapiamanual.com.br/terapia-manual/2013/03/ 21/existe-papel-para-a-terapia-manual-nas-dores-abdominais/. Acessado em: 03 jan. 2015. Citado na página 20. 
ULLRICH, S.; KUHLEN, T. Haptic palpation for medical simulation in virtual environments. Visualization and Computer Graphics, IEEE Transactions on, v. 18, n. 4, p. 617-625, April 2012. ISSN 1077-2626. Citado 7 vezes nas páginas 28, 46, 50, 52, 68, 69 e 110.

ULLRICH, S. et al. Haptic pulse simulation for virtual palpation. In: Bildverarbeitung für die Medizin 2008. [S.l.]: Springer, 2008. p. 187-191. Citado 2 vezes nas páginas 46 e 116.

VÅPENSTAD, C. et al. Perceiving haptic feedback in virtual reality simulators. Surgical endoscopy, Springer, v. 27, n. 7, p. 2391-2397, 2013. Citado na página 29.

VEITCH, D. et al. The development of a lifelike breast cancer patient simulator using anthropometric data. In: Ergonomics Australia-HFESA 2011 Conference Edition. [S.l.: s.n.], 2011. Citado na página 42.

VRLAB. 2015. <http://www.vrlab.ctw.utwente.nl/equipment.html/. Acessado em: 03 jan. 2015. Citado na página 84.

VUSKOVIC, V. et al. Realistic force feedback for virtual reality based diagnostic surgery simulators. In: Robotics and Automation, 2000. Proceedings. ICRA '00. IEEE International Conference on. [S.l.: s.n.], 2000. v. 2, p. 1592-1598 vol.2. ISSN 1050-4729. Citado na página 49.

WIDMER, A.; HU, Y. Difference of perceiving object softness during palpation through single-node and multi-node contacts. In: Engineering in Medicine and Biology Society (EMBC), 2012 Annual International Conference of the IEEE. [S.l.: s.n.], 2012. p. 936-939. ISSN 1557-170X. Citado na página 109.

WIECHA, J.; GANN, P. Provider confidence in breast examination. Family practice research journal, v. 13, n. 1, p. 37-41, March 1993. ISSN 0270-2304. Disponível em: <http://europepmc.org/abstract/MED/8484339>. Citado na página 17.

WILLIAMS II, R. L. et al. The virtual haptic back for palpatory training. In: Proceedings of the 6th International Conference on Multimodal Interfaces. New York, NY, USA: ACM, 2004. (ICMI '04), p. 191-197. ISBN 1-58113-995-0. Disponível em: $<$ http://doi.acm.org/10.1145/1027933.1027966>. Citado 5 vezes nas páginas 20, 21, 45, 52 e 114.

WILLIS, R. E. et al. Virtual reality simulators: valuable surgical skills trainers or video games? Journal of surgical education, v. 71, n. 3, p. 426-433, 2014. ISSN 1931-7204. Disponível em: <http://dx.doi.org/10.1016/j.jsurg.2013.11.003>. Citado na página 29.

ZHONG, Y. et al. An electromechanical based deformable model for soft tissue simulation. Artif. Intell. Med., Elsevier Science Publishers Ltd., Essex, UK, v. 47, n. 3, p. 275-288, nov. 2009. ISSN 0933-3657. Disponível em: <http://dx.doi.org/10.1016/j.artmed.2009.08.003>. Citado 2 vezes nas páginas 49 e 108. 


\section{Apêndice A - Protocolo de Revisão Sistemática}

OBJETIVO: Identificar e analisar as técnicas e ferramentas existentes para simulação de exame de palpação com retorno háptico.

\section{QUESTÃO DE PESQUISA:}

-Quais são as técnicas e ferramentas existentes para simular exame de palpação com retorno háptico?

População: Projetos de simulação de exame de palpação com retorno háptico.

Intervenção: Técnicas e ferramentas para simulação.

Resultados esperados: Identificação e análise de técnicas e ferramentas existentes para simulação de exame de palpação com retorno háptico.

Aplicação: Os resultados da RS pretendem contribuir com pesquisadores da área de Realidade Virtual que desenvolvem sistemas de simulação voltados à área de treinamento médico.

CRITÉRIOS PARA A SELEÇÃO DE FONTES: A fim de serem selecionadas, as fontes devem seguir os critérios abaixo:

-Bibliotecas digitais on-line

-Bases eletrônicas indexadas

- Anais de eventos de área

-Teses e dissertações

MÉTODO DE BUSCA: Este processo será realizado por meio de buscas formadas por palavras-chave. Os trabalhos serão encontrados a partir de pesquisas realizadas em portais de busca de artigos, teses, dissertações e periódicos. Durante o procedimento de recuperação das informações serão consideradas as strings encontradas preferencialmente em Títulos, Resumos e Palavras-chave de cada base de dados. Após a realização dos resumos, e verificando-se a relevância do trabalho, ele será selecionado para leitura em sua totalidade. Em seguida, serão arquivados em pastas, separando-os de acordo com a base de dados na qual o trabalho foi encontrado. Nessa etapa, iremos confeccionar e executar strings de busca em cada uma das fontes selecionadas, documentando e registrando os trabalhos em um formulário de condução da revisão, mediante a leitura dos resumos das obras, evitando-se o registro repetido de obras idênticas a partir de critérios de inclusão e exclusão.

CRITÉRIOS DE QUALIDADE DOS ESTUDOS PRIMÁRIOS: Serão considerados preferencialmente artigos que apresentem técnicas ou ferramentas que simulem qualquer tipo de exame de palpação com retorno háptico e que também apresentem e descrevam algum tipo de avaliação e validação da tecnologia apresentada no estudo. 
- PubMed

- IEEE Xplore Digital Library

- ACM Digital Library

- Biblioteca Digital de Teses e Dissertações da USP

PALAVRAS-CHAVE: Para a realização das buscas, procurar-se-á utilizar a composição de termos apresentada a seguir de forma que tais termos-chave estejam presentes ou no título ou no resumo ou nas palavras-chave do trabalho indexado na base: ("force feedback" OR haptic* OR tactile) AND (palpation OR simulation OR ((surgical OR medical) AND training)).

CRITÉRIOS DE INCLUSÃO DOS ESTUDOS PRIMÁRIOS: Serão incluídos trabalhos que atendem ao menos um dos critérios listados abaixo:

(a) apresentar técnicas ou ferramentas que simulem exame de palpação com retorno háptico;

(b) usar ou referenciar técnicas ou ferramentas que simulem exame de palpação com retorno háptico.

CRITÉRIOS DE EXCLUSÃO DOS ESTUdOS PRIMÁRIOS: Serão excluídos trabalhos:

(c) que apresentem técnicas ou ferramentas que simulem palpação sem retorno háptico;

(d) duplicados;

(e) que não apresentem abstract/resumo.

PROCESSO DE SELEÇÃO DOS TRABALHOS: Os estudos primários recuperados serão avaliados de uma forma geral por meio dos critérios de inclusão e exclusão definidos. Desse modo, uma pré-avaliação (por meio do título e do resumo) será realizada a fim de se selecionar os trabalhos de interesse que serão incluídos na revisão. Os textos selecionados na pré-avaliação deverão ser lidos na íntegra e avaliados rigorosamente de acordo com os mesmos critérios. Nessa etapa, possíveis trabalhos que não se mostrem interessantes, de acordo com os objetivos da revisão, ainda poderão ser excluídos. Os trabalhos de interesse serão, então, utilizados na elaboração de discussões que objetivam responder as questões definidas.

ESTRATÉGIA DE EXTRAÇÃO DE INFORMAÇÕES RELEVANTES: Serão extraídas informações tais como: objetivo do trabalho, tipo de avaliação utilizada (se houver), trabalhos futuros, área de aplicação, tipo de dispositivo háptico utilizado, nome do algoritmo usado, dispositivo de visualização, pontos de contato, dificuldades da área, tendências da área.

SUMARIZAÇÃO DOS RESULTADOS: Relatório técnico, que contemple uma análise qualitativa de técnicas e ferramentas de simulação de exame de palpação com retorno háptico. Tabelas, gráficos e outras formas de representação, que permitam ilustrar 
de forma quantitativa as avaliações das técnicas e ferramentas presentes nas metodologias analisadas, junto da descrição das avaliações. 


\section{Apêndice B - Tabela de artigos incluídos na Revisão Sistemática}

Tabela 7 - Artigos incluídos na Revisão Sistemática

\begin{tabular}{|c|c|c|c|c|}
\hline Artigo & Descrição & $\begin{array}{l}\text { Área de } \\
\text { Aplicação }\end{array}$ & $\begin{array}{l}\text { Dispositivo } \\
\text { Háptico }\end{array}$ & Algoritmo \\
\hline $\begin{array}{l}\text { (HOSSEINI et } \\
\text { al., 2010) }\end{array}$ & $\begin{array}{l}\text { Instrumento de } \\
\text { sensoriamento } \\
\text { tátil para detectar } \\
\text { objetos anormais } \\
\text { em modelos } \\
\text { simulados }\end{array}$ & $\begin{array}{ll}\text { Palpação } & \\
\text { para } & \text { de- } \\
\text { tecção } & \text { de } \\
\text { câncer } & \end{array}$ & $\begin{array}{l}\text { Force sensing } \\
\text { resistor }\end{array}$ & $\begin{array}{l}\text { Método dos } \\
\text { elementos fi- } \\
\text { nitos }\end{array}$ \\
\hline $\begin{array}{l}\text { (PARKES; } \\
\text { FORREST; } \\
\text { BAILLIE, } \\
2009)\end{array}$ & $\begin{array}{l}\text { Desenvolvimento } \\
\text { de um simula- } \\
\text { dor de palpação } \\
\text { abdominal felina }\end{array}$ & $\begin{array}{l}\text { Medicina ve- } \\
\text { terinária }\end{array}$ & $\begin{array}{l}\text { Phantom } \\
\text { Premium } 1.5\end{array}$ & $\begin{array}{l}\text { Não infor- } \\
\text { mado }\end{array}$ \\
\hline $\begin{array}{l}\text { (ZHONG et al., } \\
2009)\end{array}$ & $\begin{array}{l}\text { Modelo para simu- } \\
\text { lar deformação de } \\
\text { tecidos moles do } \\
\text { ponto de vista ele- } \\
\text { tromecânico }\end{array}$ & $\begin{array}{l}\text { Palpação ci- } \\
\text { rúrgica }\end{array}$ & Phantom & $\begin{array}{l}\text { Não infor- } \\
\text { mado }\end{array}$ \\
\hline $\begin{array}{l}\text { (BASAFA; } \\
\text { SEFATI; } \\
\text { OKAMURA, } \\
2011)\end{array}$ & $\begin{array}{l}\text { Método massa- } \\
\text { mola não linear } \\
\text { para simulação } \\
\text { em tempo real } \\
\text { de tecidos moles } \\
\text { deformáveis com } \\
\text { retorno de força }\end{array}$ & $\begin{array}{l}\text { Palpação ci- } \\
\text { rúrgica }\end{array}$ & $\begin{array}{l}\text { Phantom } \\
\text { Premium } 1.5\end{array}$ & $\begin{array}{l}\text { Algoritmo } \\
\text { massa-mola } \\
\text { para mode- } \\
\text { lagem de } \\
\text { objetos moles }\end{array}$ \\
\hline $\begin{array}{l}\text { (KARADOGAN } \\
\text { et al., 2010) }\end{array}$ & $\begin{array}{l}\text { Experimento de } \\
\text { discriminação de } \\
\text { rigidez com estu- } \\
\text { dantes de Medi- } \\
\text { cina }\end{array}$ & $\begin{array}{ll}\text { Palpação } & \\
\text { para } & \text { de- } \\
\text { tecção } & \text { de } \\
\text { câncer } & \end{array}$ & $\begin{array}{l}\text { Phantom } \\
\text { Omni }\end{array}$ & $\begin{array}{l}\text { Não infor- } \\
\text { mado }\end{array}$ \\
\hline $\begin{array}{l}\text { (EVERETT et } \\
\text { al., 2009) }\end{array}$ & $\begin{array}{l}\text { Aparato físico que } \\
\text { oferece retorno } \\
\text { háptico durante a } \\
\text { palpação de uma } \\
\text { superfície externa }\end{array}$ & $\begin{array}{l}\text { Toracostomia } \\
\text { com tubo }\end{array}$ & $\begin{array}{l}\text { Phantom } \\
\text { Omni }\end{array}$ & $\begin{array}{l}\text { Não infor- } \\
\text { mado }\end{array}$ \\
\hline
\end{tabular}




\begin{tabular}{|c|c|c|c|c|}
\hline $\begin{array}{l}\text { (HOSSEINI et } \\
\text { al., 2006) }\end{array}$ & $\begin{array}{l}\text { Método para mo- } \\
\text { delagem de tecido } \\
\text { contendo um nó- } \\
\text { dulo }\end{array}$ & $\begin{array}{ll}\text { Palpação } & \\
\text { para } & \text { de- } \\
\text { tecção } & \text { de } \\
\text { câncer } & \end{array}$ & $\begin{array}{ll}\text { Não infor- } \\
\text { mado }\end{array}$ & $\begin{array}{l}\text { Método dos } \\
\text { elementos fi- } \\
\text { nitos }\end{array}$ \\
\hline $\begin{array}{l}\text { (TOKUYASU } \\
\text { et al., 2010) }\end{array}$ & $\begin{array}{l}\text { Desenvolvimento } \\
\text { de um sistema de } \\
\text { simulação cirúr- } \\
\text { gica, que permite } \\
\text { o treinamento } \\
\text { da palpação do } \\
\text { músculo cardíaco }\end{array}$ & $\begin{array}{l}\text { Palpação ci- } \\
\text { rúrgica }\end{array}$ & $\begin{array}{l}\text { Phantom } \\
\text { Premium }\end{array}$ & Massa-mola \\
\hline $\begin{array}{l}\text { (WIDMER; } \\
\text { HU, 2012) }\end{array}$ & $\begin{array}{l}\text { Avaliação da per- } \\
\text { cepção de efeitos } \\
\text { hápticos e visuais } \\
\text { em aplicações de } \\
\text { RV }\end{array}$ & $\begin{array}{ll}\text { Palpação } & \\
\text { para de- } & \text { decção } \\
\text { câncer } & \end{array}$ & Phantom 1.5 & $\begin{array}{l}\text { Não infor- } \\
\text { mado }\end{array}$ \\
\hline $\begin{array}{l}\text { (KESNER; } \\
\text { HOWE, 2011) }\end{array}$ & $\begin{array}{l}\text { Desenvolvimento } \\
\text { de um sistema de } \\
\text { cateter que per- } \\
\text { mite a percepção } \\
\text { háptica de estru- } \\
\text { turas de tecido de } \\
\text { movimento rápido }\end{array}$ & $\begin{array}{l}\text { Procedimento } \\
\text { de inserção } \\
\text { de cateter }\end{array}$ & $\begin{array}{l}\text { Dispositivo } \\
\text { próprio }\end{array}$ & $\begin{array}{l}\text { Não infor- } \\
\text { mado }\end{array}$ \\
\hline $\begin{array}{l}\text { (LANGRANA } \\
\text { et al., 1994) }\end{array}$ & $\begin{array}{l}\text { Desenvolvimento } \\
\text { do modelo virtual } \\
\text { de um joelho } \\
\text { com músculos, } \\
\text { ligamentos e ossos }\end{array}$ & $\begin{array}{l}\text { Palpação ci- } \\
\text { rúrgica }\end{array}$ & $\begin{array}{l}\text { DataGlove e } \\
\text { Rutgers Mas- } \\
\text { ter }\end{array}$ & Bounding box \\
\hline $\begin{array}{l}\text { (BAILLIE et } \\
\text { al., 2010) }\end{array}$ & \begin{tabular}{lr}
\multicolumn{2}{l}{ Desenvolvimento } \\
de um & simulador \\
para & ensinar \\
palpação & retal \\
bovina &
\end{tabular} & $\begin{array}{l}\text { Palpação ve- } \\
\text { terinária }\end{array}$ & $\begin{array}{l}\text { Phantom } \\
\text { Premium } 1.5\end{array}$ & $\begin{array}{l}\text { Não infor- } \\
\text { mado }\end{array}$ \\
\hline $\begin{array}{l}\text { (MCCREERY } \\
\text { et al., 2007) }\end{array}$ & $\begin{array}{l}\text { Realização de } \\
\text { experimentos } \\
\text { em pulmões suí- } \\
\text { nos utilizando } \\
\text { nódulos artificiais }\end{array}$ & $\begin{array}{ll}\text { Palpação } & \\
\text { para de- } \\
\text { tecção de } \\
\text { câncer }\end{array}$ & Gamma & $\begin{array}{l}\text { Não infor- } \\
\text { mado }\end{array}$ \\
\hline
\end{tabular}




\begin{tabular}{|c|c|c|c|c|}
\hline $\begin{array}{l}\text { (MAHVASH et } \\
\text { al., 2008) }\end{array}$ & $\begin{array}{l}\text { Desenvolvimento } \\
\text { de um operador } \\
\text { telecirúrgico } \\
\text { com seis graus } \\
\text { de liberdade e } \\
\text { quatro modos de } \\
\text { operação possíveis }\end{array}$ & $\begin{array}{l}\text { Palpação ci- } \\
\text { rúrgica }\end{array}$ & $\begin{array}{l}\text { Da Vinci } \\
\text { surgical sys- } \\
\text { tem/Sistema } \\
\text { de controle } \\
\text { personali- } \\
\text { zado }\end{array}$ & $\begin{array}{l}\text { Não infor- } \\
\text { mado }\end{array}$ \\
\hline $\begin{array}{l}\text { (NAKAGAWA; } \\
\text { OGURO, } \\
2009)\end{array}$ & $\begin{array}{l}\text { Desenvolvimento } \\
\text { de um sistema } \\
\text { de treinamento } \\
\text { de palpação } \\
\text { mecânica para } \\
\text { tratamento do } \\
\text { músculo cardíaco } \\
\text { e proposição de } \\
\text { um modelo de } \\
\text { sistema de mola }\end{array}$ & $\begin{array}{l}\text { Palpação ci- } \\
\text { rúrgica }\end{array}$ & Linear Slider & Massa-mola \\
\hline $\begin{array}{l}\text { (ULLRICH; } \\
\text { KUHLEN, } \\
2012)\end{array}$ & $\begin{array}{l}\text { Apresentação de } \\
\text { um algoritmo de } \\
\text { interação para pal- } \\
\text { pação com arrasto } \\
\text { de tecido }\end{array}$ & $\begin{array}{l}\text { Palpação ar- } \\
\text { terial }\end{array}$ & $\begin{array}{l}\text { Phantom } \\
\text { Omni }\end{array}$ & $\begin{array}{l}\text { Método dos } \\
\text { elementos fi- } \\
\text { nitos }\end{array}$ \\
\hline $\begin{array}{l}\text { (STALFORS et } \\
\text { al., 2001) }\end{array}$ & $\begin{array}{l}\text { Desenvolvimento } \\
\text { de um modelo } \\
\text { tridimensional da } \\
\text { região da cabeça } \\
\text { e pescoço para } \\
\text { estudo de câncer } \\
\text { nestas regiões. }\end{array}$ & $\begin{array}{ll}\text { Palpação } & \\
\text { para } & \text { de- } \\
\text { tecção de } & \text { de } \\
\text { câncer } & \end{array}$ & Phantom & $\begin{array}{l}\text { Não infor- } \\
\text { mado }\end{array}$ \\
\hline $\begin{array}{l}\text { (JEON et al., } \\
2010)\end{array}$ & $\begin{array}{l}\text { Estudo de caso } \\
\text { de sistema previ- } \\
\text { amente desenvol- } \\
\text { vido para palpa- } \\
\text { ção de nódulo da } \\
\text { mama }\end{array}$ & $\begin{array}{ll}\text { Palpação } & \\
\text { para de- } & \text { de- } \\
\text { teç̧ão } & \text { de } \\
\text { câncer } & \end{array}$ & $\begin{array}{l}\text { Phantom } \\
\text { Premium } 1.5\end{array}$ & $\begin{array}{l}\text { Não infor- } \\
\text { mado }\end{array}$ \\
\hline
\end{tabular}




\begin{tabular}{|c|c|c|c|c|}
\hline $\begin{array}{l}\text { (LUBOZ et al., } \\
2013)\end{array}$ & $\begin{array}{l}\text { Desenvolvimento } \\
\text { de um simulador } \\
\text { virtual da técnica } \\
\text { de Seldinger }\end{array}$ & $\begin{array}{l}\text { Radiologia in- } \\
\text { tervencional }\end{array}$ & $\begin{array}{l}\text { Phantom } \\
\text { Omni/Vascular } \\
\text { Simulation } \\
\text { Platform }\end{array}$ & $\begin{array}{l}\text { Método } \\
\text { dos elemen- } \\
\text { tos fini- } \\
\text { tos/Método } \\
\text { massa-mola }\end{array}$ \\
\hline $\begin{array}{l}\text { (KIM et al., } \\
2009)\end{array}$ & $\begin{array}{l}\text { Desenvolvimento } \\
\text { de um framework } \\
\text { de um sistema de } \\
\text { palpação háptica } \\
\text { em tempo real }\end{array}$ & \begin{tabular}{ll}
\multicolumn{2}{l}{ Palpação } \\
para de- \\
tecção de \\
câncer
\end{tabular} & $\begin{array}{l}\text { Phantom } \\
\text { Premium } 1.0\end{array}$ & $\begin{array}{l}\text { Método dos } \\
\text { elementos fi- } \\
\text { nitos }\end{array}$ \\
\hline $\begin{array}{l}\text { (PERRI et al., } \\
2010)\end{array}$ & $\begin{array}{l}\text { Calibração de um } \\
\text { instrumento de } \\
\text { sensação tátil e } \\
\text { sua integração } \\
\text { com uma interface } \\
\text { de visualização }\end{array}$ & $\begin{array}{l}\text { Palpação ci- } \\
\text { rúrgica }\end{array}$ & TactArray & $\begin{array}{l}\text { Não infor- } \\
\text { mado }\end{array}$ \\
\hline $\begin{array}{l}\text { (COLES et al., } \\
2011 \text { ) }\end{array}$ & $\begin{array}{l}\text { Desenvolvimento } \\
\text { de um ambiente } \\
\text { de treinamento } \\
\text { de palpação da } \\
\text { artéria femoral } \\
\text { e inserção de } \\
\text { agulha }\end{array}$ & $\begin{array}{l}\text { Radiologia in- } \\
\text { tervencional }\end{array}$ & Falc & $\begin{array}{l}\text { Não infor- } \\
\text { mado }\end{array}$ \\
\hline $\begin{array}{l}\text { (KURODA et } \\
\text { al., 2005) }\end{array}$ & $\begin{array}{l}\text { Descrição de um } \\
\text { método para re- } \\
\text { presentar intera- } \\
\text { ção em tempo real } \\
\text { entre objetos elás- } \\
\text { ticos }\end{array}$ & $\begin{array}{ll}\text { Palpação } & \\
\text { para de- } & \text { de } \\
\text { teç̧ão } & \text { de } \\
\text { câncer } & \end{array}$ & $\begin{array}{l}\text { Phantom } \\
\text { Premium } 1.0\end{array}$ & $\begin{array}{l}\text { Modelo está- } \\
\text { tico e linear } \\
\text { e técnicas de } \\
\text { computação } \\
\text { rápida como } \\
\text { condensação } \\
\text { e método de } \\
\text { Hirota }\end{array}$ \\
\hline $\begin{array}{l}\text { (CHOI; SUN; } \\
\text { HENG, 2003) }\end{array}$ & $\begin{array}{l}\text { Proposição de um } \\
\text { modelo deformá- } \\
\text { vel baseado num } \\
\text { processo de propa- } \\
\text { gação de força su- } \\
\text { cessiva }\end{array}$ & $\begin{array}{l}\text { Palpação ci- } \\
\text { rúrgica }\end{array}$ & $\begin{array}{l}\text { Phantom } \\
\text { Desktop }\end{array}$ & Massa-mola \\
\hline
\end{tabular}




\begin{tabular}{|c|c|c|c|c|}
\hline $\begin{array}{l}\text { (HAMAMOTO, } \\
2006)\end{array}$ & $\begin{array}{l}\text { Exibição de infor- } \\
\text { mação de elastici- } \\
\text { dade num display } \\
\text { háptico, para um } \\
\text { sistema de palpa- } \\
\text { ção virtual }\end{array}$ & $\begin{array}{ll}\text { Palpação } & \\
\text { para } & \text { de- } \\
\text { tecção } & \text { de } \\
\text { câncer } & \end{array}$ & $\begin{array}{l}\text { Phantom } \\
\text { Desktop }\end{array}$ & $\begin{array}{l}\text { Não infor- } \\
\text { mado }\end{array}$ \\
\hline $\begin{array}{l}\text { (SATAVA, } \\
1995)\end{array}$ & $\begin{array}{l}\text { Revisão sobre apli- } \\
\text { cações médicas de } \\
\text { realidade virtual }\end{array}$ & Todas & Vários & Vários \\
\hline $\begin{array}{l}\text { (FRISOLI; } \\
\text { BORELLI; } \\
\text { BERGA- } \\
\text { MASCO; } \\
2005)\end{array}$ & $\begin{array}{l}\text { Descrição de um } \\
\text { método numérico } \\
\text { para implementar } \\
\text { deformação de te- } \\
\text { cidos moles para } \\
\text { retorno háptico }\end{array}$ & $\begin{array}{l}\text { Palpação ci- } \\
\text { rúrgica }\end{array}$ & $\begin{array}{ll}\text { Não infor- } \\
\text { mado }\end{array}$ & $\begin{array}{l}\text { Método dos } \\
\text { elementos fi- } \\
\text { nitos }\end{array}$ \\
\hline $\begin{array}{l}\text { (KHALED et } \\
\text { al., 2003) }\end{array}$ & $\begin{array}{l}\text { Sistema háptico } \\
\text { para visualizar e } \\
\text { reconstruir propri- } \\
\text { edades mecânicas } \\
\text { do tecido }\end{array}$ & \begin{tabular}{ll}
\multicolumn{2}{l}{ Palpação } \\
para de- \\
tecção de \\
câncer
\end{tabular} & $\begin{array}{l}\text { Dispositivo } \\
\text { próprio }\end{array}$ & $\begin{array}{l}\text { Método dos } \\
\text { elementos fi- } \\
\text { nitos }\end{array}$ \\
\hline $\begin{array}{l}\text { (HOWELL et } \\
\text { al., 2008a) }\end{array}$ & $\begin{array}{l}\text { Examinar a efi- } \\
\text { cácia do Virtual } \\
\text { Haptic Back no } \\
\text { treinamento de es- } \\
\text { tudantes de osteo- } \\
\text { patia em diagnós- } \\
\text { tico palpatório }\end{array}$ & Osteopatia & Phantom 1.5 & $\begin{array}{l}\text { Não infor- } \\
\text { mado }\end{array}$ \\
\hline $\begin{array}{l}\text { (LEE et al., } \\
2013)\end{array}$ & $\begin{array}{l}\text { Desenvolvimento } \\
\text { de um sistema de } \\
\text { realidade aumen- } \\
\text { tada com retorno } \\
\text { háptico e visual } \\
\text { para simulação de } \\
\text { rugas na pele }\end{array}$ & Dermatologia & $\begin{array}{l}\text { Phantom } \\
\text { Omni }\end{array}$ & $\begin{array}{l}\text { Não infor- } \\
\text { mado }\end{array}$ \\
\hline
\end{tabular}




\begin{tabular}{|c|c|c|c|c|}
\hline $\begin{array}{l}\text { (TALASAZ; } \\
\text { PATEL, 2012) }\end{array}$ & $\begin{array}{l}\text { Apresentação de } \\
\text { um método inte- } \\
\text { grado de força tá- } \\
\text { til para localizar } \\
\text { tumores de forma } \\
\text { minimamente in- } \\
\text { vasiva utilizando } \\
\text { robôs }\end{array}$ & $\begin{array}{l}\text { Palpação ci- } \\
\text { rúrgica }\end{array}$ & $\begin{array}{l}\text { Quanser } \\
\text { Haptic Wand }\end{array}$ & $\begin{array}{l}\text { Não infor- } \\
\text { mado }\end{array}$ \\
\hline $\begin{array}{l}\text { (JEON; CHOI; } \\
\text { HARDERS, } \\
2012)\end{array}$ & $\begin{array}{l}\text { Exame do uso de } \\
\text { aumento no con- } \\
\text { texto da palpa- } \\
\text { ção de nódulo na } \\
\text { mama }\end{array}$ & $\begin{array}{ll}\text { Palpação } & \\
\text { para } & \text { de- } \\
\text { tecção } & \text { de } \\
\text { câncer } & \end{array}$ & $\begin{array}{l}\text { Phantom } \\
\text { Premium } 1.5\end{array}$ & $\begin{array}{l}\text { Não infor- } \\
\text { mado }\end{array}$ \\
\hline $\begin{array}{l}\text { (BAJAJ et al., } \\
2008)\end{array}$ & $\begin{array}{l}\text { Descrição de um } \\
\text { experimento que } \\
\text { buscou verificar a } \\
\text { retenção das ha- } \\
\text { bilidades de indi- } \\
\text { víduos treinados } \\
\text { no Virtual Haptic } \\
\text { Back após seis me- } \\
\text { ses da realização } \\
\text { do primeiro treina- } \\
\text { mento }\end{array}$ & Osteopatia & Phantom 3.0 & $\begin{array}{ll}\text { Não infor- } \\
\text { mado }\end{array}$ \\
\hline $\begin{array}{l}\text { (KINNISON et } \\
\text { al., 2009) }\end{array}$ & $\begin{array}{l}\text { Ensino de anato- } \\
\text { mia abdominal } \\
\text { bovina básica } \\
\text { usando um simu- } \\
\text { lador háptico de } \\
\text { palpação retal }\end{array}$ & $\begin{array}{l}\text { Palpação ve- } \\
\text { terinária }\end{array}$ & $\begin{array}{l}\text { Phantom } \\
\text { Premium }\end{array}$ & $\begin{array}{ll}\text { Não infor- } \\
\text { mado }\end{array}$ \\
\hline $\begin{array}{l}\text { (ROKE et al., } \\
2013)\end{array}$ & $\begin{array}{l}\text { Investigação dos } \\
\text { efeitos de retorno } \\
\text { de força lateral na } \\
\text { detecção e locali- } \\
\text { zação de nódulos } \\
\text { embutidos em te- } \\
\text { cidos moles }\end{array}$ & $\begin{array}{ll}\text { Palpação } & \\
\text { para } & \text { de- } \\
\text { tecção } & \text { de } \\
\text { câncer } & \end{array}$ & $\begin{array}{l}\text { TACTIP } \mathrm{e} \\
\text { Falcon }\end{array}$ & $\begin{array}{l}\text { Não infor- } \\
\text { mado }\end{array}$ \\
\hline
\end{tabular}




\begin{tabular}{|c|c|c|c|c|}
\hline $\begin{array}{l}\text { (COLES; ME- } \\
\text { GLAN; JOHN, } \\
2011)\end{array}$ & $\begin{array}{l}\text { Survey que dis- } \\
\text { cute o papel dos } \\
\text { recursos hápticos } \\
\text { em aplicações de } \\
\text { treinamento mé- } \\
\text { dico }\end{array}$ & Todas & Vários & Vários \\
\hline $\begin{array}{l}\text { (OTTERMO et } \\
\text { al., 2006) }\end{array}$ & $\begin{array}{l}\text { Descrição de dois } \\
\text { experimentos } \\
\text { que comparam } \\
\text { diferentes tipos } \\
\text { de palpação }\end{array}$ & $\begin{array}{l}\text { Palpação ci- } \\
\text { rúrgica }\end{array}$ & TactArray & $\begin{array}{l}\text { Não infor- } \\
\text { mado }\end{array}$ \\
\hline $\begin{array}{l}\text { (HOWELL et } \\
\text { al., 2008b) }\end{array}$ & $\begin{array}{l}\text { Descrição de ses- } \\
\text { sões práticos com } \\
\text { o simulador Vir- } \\
\text { tual Haptic Back }\end{array}$ & Osteopatia & Phantom 3.0 & $\begin{array}{l}\text { Não infor- } \\
\text { mado }\end{array}$ \\
\hline $\begin{array}{l}\text { (WILLIAMS II } \\
\text { et al., 2004) }\end{array}$ & $\begin{array}{l}\text { Desenvolvimento } \\
\text { de um simulador } \\
\text { do dorso humano }\end{array}$ & Osteopatia & Phantom 3.0 & $\begin{array}{l}\text { Não infor- } \\
\text { mado }\end{array}$ \\
\hline $\begin{array}{l}\text { (D'AULIGNAC } \\
\text { et al., 2006) }\end{array}$ & $\begin{array}{l}\text { Desenvolvimento } \\
\text { de um simulador } \\
\text { de palpação de } \\
\text { trombose }\end{array}$ & Ecografia & $\begin{array}{l}\text { Phantom } \\
\text { Premium }\end{array}$ & $\begin{array}{l}\text { Não infor- } \\
\text { mado }\end{array}$ \\
\hline $\begin{array}{l}\text { (BAILLIE et } \\
\text { al., 2005) }\end{array}$ & $\begin{array}{l}\text { Validação de um } \\
\text { simulador de pal- } \\
\text { pação retal bovina }\end{array}$ & $\begin{array}{l}\text { Palpação ve- } \\
\text { terinária }\end{array}$ & Phantom & $\begin{array}{l}\text { Não infor- } \\
\text { mado }\end{array}$ \\
\hline $\begin{array}{l}\text { (BAILLIE et } \\
\text { al., 2005) }\end{array}$ & $\begin{array}{lr}\text { Integração } & \text { do } \\
\text { simulador } & \text { a } \\
\text { um curso } & \text { de } \\
\text { veterinária } & \end{array}$ & $\begin{array}{l}\text { Palpação ve- } \\
\text { terinária }\end{array}$ & Phantom & $\begin{array}{l}\text { Não infor- } \\
\text { mado }\end{array}$ \\
\hline $\begin{array}{l}\text { (BURDEA et } \\
\text { al., 1999) }\end{array}$ & $\begin{array}{l}\text { Desenvolvimento } \\
\text { de um simulador } \\
\text { para diagnóstico } \\
\text { de câncer de } \\
\text { próstata }\end{array}$ & $\begin{array}{ll}\text { Palpação } & \\
\text { para } & \text { de- } \\
\text { tecção } & \text { de } \\
\text { câncer } & \end{array}$ & $\begin{array}{l}\text { Phantom } \\
\text { Premium }\end{array}$ & $\begin{array}{ll}\text { Não infor- } \\
\text { mado }\end{array}$ \\
\hline $\begin{array}{l}\text { (GLADSTONE } \\
\text { et al., 2000) }\end{array}$ & $\begin{array}{l}\text { Desenvolvimento } \\
\text { de um simula- } \\
\text { dor de palpação } \\
\text { cirúrgica }\end{array}$ & $\begin{array}{l}\text { Palpação ci- } \\
\text { rúrgica }\end{array}$ & Phantom & $\begin{array}{l}\text { Método dos } \\
\text { elementos fi- } \\
\text { nitos }\end{array}$ \\
\hline
\end{tabular}




\begin{tabular}{|c|c|c|c|c|}
\hline $\begin{array}{l}\text { MACHADO; } \\
\text { MORAES, } \\
2006)\end{array}$ & $\begin{array}{l}\text { Desenvolvimento } \\
\text { de um simula- } \\
\text { dor de RV para } \\
\text { educação na } \\
\text { prática de exames } \\
\text { ginecológicos }\end{array}$ & Ginecologia & $\begin{array}{l}\text { Phantom } \\
\text { Omni }\end{array}$ & $\begin{array}{l}\text { Não infor- } \\
\text { mado }\end{array}$ \\
\hline $\begin{array}{l}\text { (SUZUKI et al., } \\
1998)\end{array}$ & $\begin{array}{l}\text { Desenvolvimento } \\
\text { de um sistema de } \\
\text { simulação de ci- } \\
\text { rurgia, utilizando } \\
\text { o dispositivo de } \\
\text { retorno de força } \\
\text { preso aos dedos } \\
\text { polegar, indicador } \\
\text { e médio }\end{array}$ & $\begin{array}{l}\text { Palpação ci- } \\
\text { rúrgica }\end{array}$ & $\begin{array}{l}\text { Dispositivo } \\
\text { com } 16 \text { graus } \\
\text { de liberdade }\end{array}$ & $\begin{array}{l}\text { Não infor- } \\
\text { mado }\end{array}$ \\
\hline $\begin{array}{l}\text { (KURODA et } \\
\text { al., 2007) }\end{array}$ & $\begin{array}{l}\text { Simulador cirúr- } \\
\text { gico para exclusão } \\
\text { de órgãos com } \\
\text { retorno háptico } \\
\text { para vários dedos } \\
\text { e visualização de } \\
\text { estresse }\end{array}$ & $\begin{array}{l}\text { Palpação ci- } \\
\text { rúrgica }\end{array}$ & Cyberforce & $\begin{array}{l}\text { Método dos } \\
\text { elementos fi- } \\
\text { nitos }\end{array}$ \\
\hline $\begin{array}{l}\text { (KURODA et } \\
\text { al., 2007) }\end{array}$ & $\begin{array}{l}\text { Investigação da } \\
\text { taxa de renderiza- } \\
\text { ção háptica para } \\
\text { interação com dis- } \\
\text { positivo háptico } \\
\text { com retorno para } \\
\text { todos os dedos } \\
\text { e deformação de } \\
\text { tecidos moles }\end{array}$ & $\begin{array}{l}\text { Palpação ci- } \\
\text { rúrgica }\end{array}$ & force & $\begin{array}{l}\text { Método dos } \\
\text { elementos fi- } \\
\text { nitos }\end{array}$ \\
\hline $\begin{array}{l}\text { (LANGRANA } \\
\text { et al., 1997) }\end{array}$ & $\begin{array}{l}\text { Desenvolvimento } \\
\text { de simulador } \\
\text { de palpação do } \\
\text { fígado }\end{array}$ & $\begin{array}{ll}\text { Palpação } & \\
\text { para de- } & \text { decção } \\
\text { câncer } & \end{array}$ & $\begin{array}{l}\text { Rutgers Mas- } \\
\text { ter }\end{array}$ & $\begin{array}{l}\text { Método dos } \\
\text { elementos fi- } \\
\text { nitos }\end{array}$ \\
\hline
\end{tabular}




\begin{tabular}{|c|c|c|c|c|}
\hline $\begin{array}{l}\text { (DINSMORE } \\
\text { et al., 1997) }\end{array}$ & $\begin{array}{l}\text { Desenvolvimento } \\
\text { de simulador } \\
\text { de palpação do } \\
\text { fígado }\end{array}$ & $\begin{array}{ll}\text { Palpação } & \\
\text { para } & \text { de- } \\
\text { tecção } & \text { de } \\
\text { câncer } & \end{array}$ & $\begin{array}{l}\text { Rutgers Mas- } \\
\text { ter }\end{array}$ & $\begin{array}{l}\text { Método dos } \\
\text { elementos fi- } \\
\text { nitos }\end{array}$ \\
\hline $\begin{array}{l}\text { (TOKUYASU } \\
\text { et al., 2003) }\end{array}$ & $\begin{array}{l}\text { Desenvolvimento } \\
\text { de um simula- } \\
\text { dor de palpação } \\
\text { cardíaca }\end{array}$ & $\begin{array}{l}\text { Palpação ci- } \\
\text { rúrgica }\end{array}$ & $\begin{array}{l}\text { Dispositivo } \\
\text { próprio }\end{array}$ & $\begin{array}{l}\text { Não infor- } \\
\text { mado }\end{array}$ \\
\hline $\begin{array}{l}\text { (ULLRICH et } \\
\text { al., 2008) }\end{array}$ & $\begin{array}{l}\text { Desenvolvimento } \\
\text { de simulador de } \\
\text { retorno háptico } \\
\text { do pulso }\end{array}$ & $\begin{array}{l}\text { Palpação ar- } \\
\text { terial }\end{array}$ & $\begin{array}{l}\text { Phantom } \\
\text { Omni }\end{array}$ & $\begin{array}{l}\text { Não infor- } \\
\text { mado }\end{array}$ \\
\hline $\begin{array}{l}\text { (ALHALABI et } \\
\text { al., 2005) }\end{array}$ & $\begin{array}{l}\text { Desenvolvimento } \\
\text { de sistema para } \\
\text { palpação da } \\
\text { mama com vários } \\
\text { dedos }\end{array}$ & $\begin{array}{ll}\text { Palpação } & \\
\text { para de- } & \text { decção } \\
\text { câncer } & \end{array}$ & HIRO & $\begin{array}{l}\text { Método dos } \\
\text { elementos fi- } \\
\text { nitos }\end{array}$ \\
\hline $\begin{array}{l}\text { (MCLAUGHLIN } \\
\text { et al., 2003) }\end{array}$ & \begin{tabular}{l}
\multicolumn{2}{c}{ Desenvolvimento } \\
de sistema de \\
treinamento \\
de exame da \\
palpação da
\end{tabular} & $\begin{array}{ll}\text { Palpação } & \\
\text { para } & \text { de- } \\
\text { tecção } & \text { de } \\
\text { câncer } & \end{array}$ & Phantom & $\begin{array}{l}\text { Método adap- } \\
\text { tativo para } \\
\text { animação } \\
\text { de objetos } \\
\text { e cálculo de } \\
\text { retorno de } \\
\text { força }\end{array}$ \\
\hline
\end{tabular}

